\title{
WATER ALLOCATION AND THE SUSTAINABILITY OF DAIRYING IN THE UPPER WAITAKI RIVER BASIN
}

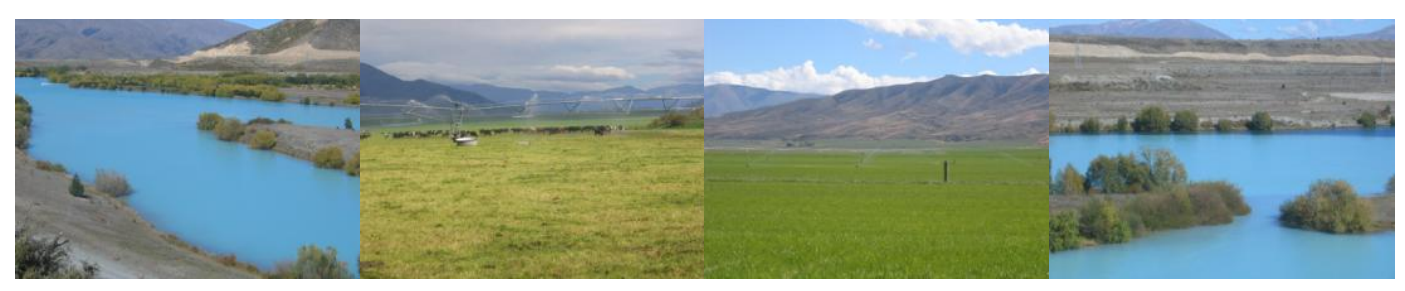

\author{
$B Y$ \\ Vicki Addison \\ ENVIRONMENTAL STUDIES 593 \\ 2009
}

A 90 point thesis submitted to Victoria University of Wellington

As partial fulfilment of requirements for the degree of Master of Environmental Studies

School of Geography, Environment and Earth Sciences

Victoria University of Wellington 


\title{
WATER ALLOCATION AND THE SUSTAINABILITY OF DAIRYING IN THE UPPER WAITAKI RIVER BASIN
}

\author{
Vicki Addison
}

\begin{abstract}
Water as a resource management issue is gaining prominence in New Zealand, both in terms of quality and quantity. In the Waitaki this became critical in 2003 when several proposed development schemes exposed the inadequacies of the RMA and highlighted the need for a catchment wide plan. Legislation was promulgated and a Regional Plan developed to address the issues of efficient allocation. This thesis aimed to question the efficiency of water allocation within the recent legislation and to examine the sustainability of dairying in this area with regard to cumulative effects to the hydrological system. It was found the Plan has failed to achieve its stated aims. Dairying in the upper Waitaki is currently increasing and applications for resource consent are being heard under legislation that is not backed by the science required within its policies. Fieldwork was undertaken to explore some of the science required under the Regional Plan to enable a 'reasonable use' test to be made. The aim was to assess the response of soils in the upper Waitaki to intensive irrigation. This revealed that the potential impacts of intensive irrigation in this area are significant and highlighted the need for further research. This is a study of how poor policy and planning, based on a lack of robust science has resulted in the inefficient allocation of water. This has implications for long-term sustainable resource use.
\end{abstract}

Key words: Dairying, Water allocation, Waitaki, Sustainability 


\section{Acknowledgements}

I would like to thank Bethanna Jackson for reading the fieldwork drafts so diligently and providing constructive and prompt feed back. The fieldwork section benefited enormously from her help. Nick Preston for having the courage to take on a student with a topic out of his area of expertise, but who still proved extremely able to provide constructive feedback. I also would like to acknowledge Guy Salmon's encouragement and support of my chosen topic - he continues to be an inspiration. Thanks must also go to Rini Hidajat from ECan for delving into the database on several occasions. To Jack McConchie, thanks must go for helping to point the way and to the Farmers of the Waitaki who welcomed me onto their land and into their homes. Thank you to you all this has been a most rewarding and enjoyable process. 


\section{Contents}

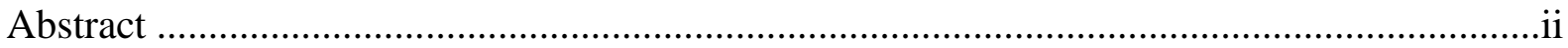

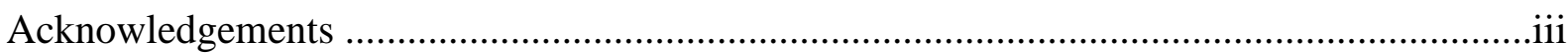

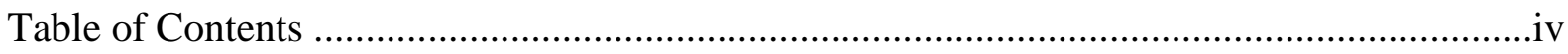

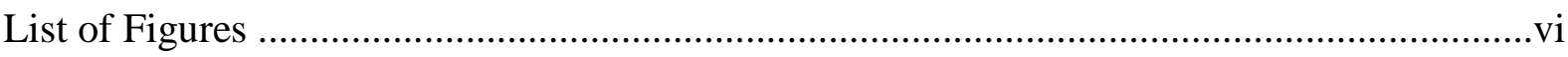

List of Photos/Maps/ Tables ..............................................................................................

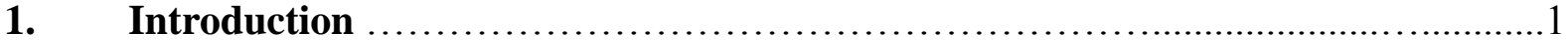

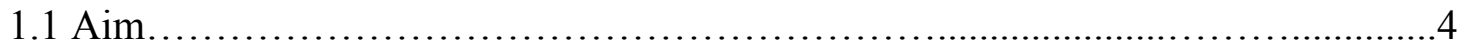

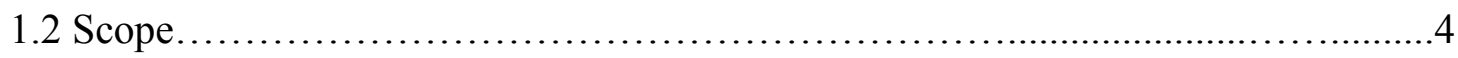

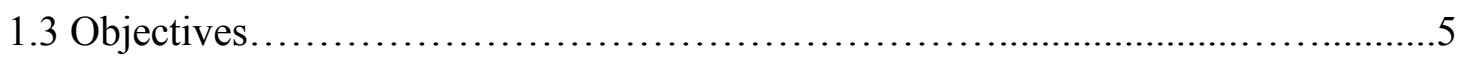

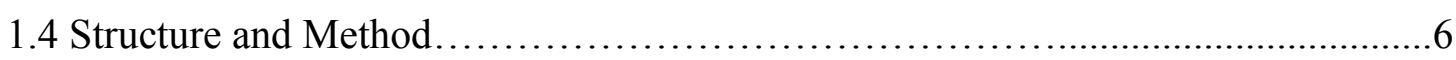

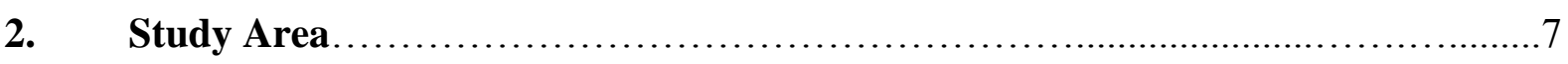

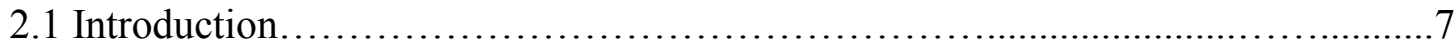

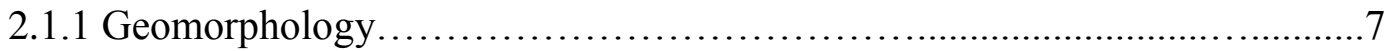

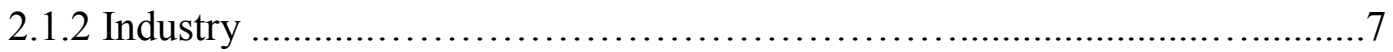

2.1.3 Visual Amenity Values ......................................................9

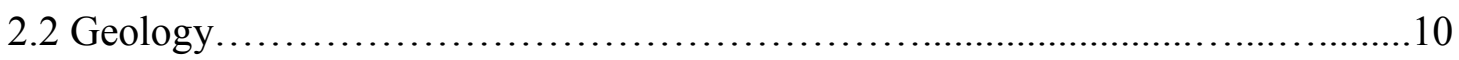

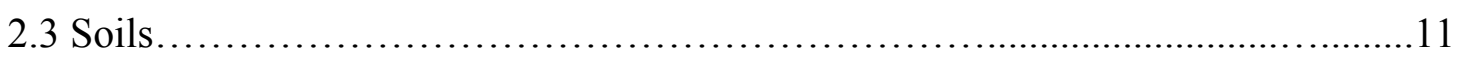

2.3.1 Soil Classification in New Zealand.........................................................11

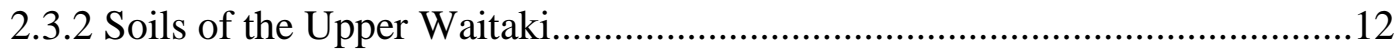

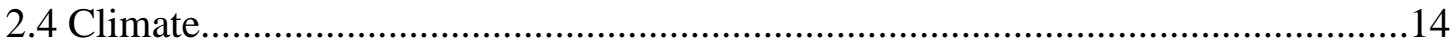

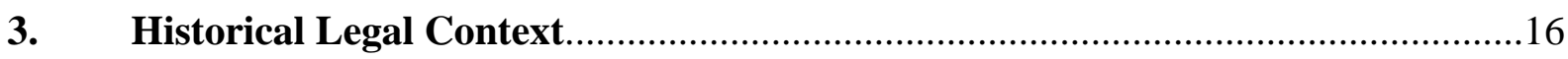

3.1 Orders in Council and Hydro Development .......................................................16

3.2 RMA 1991 and the Waitaki Catchment Amendment Act 2004 ..........................21

4. Analysis and Critique of the Waitaki Act and Waitaki Plan.............................26

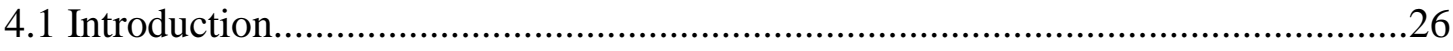

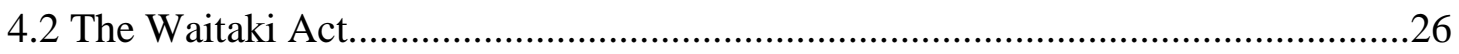

4.2.1 Exclusion of the RMA Energy and Climate Change Amendment................27

4.2.2 Removal of the National Perspective.........................................................28

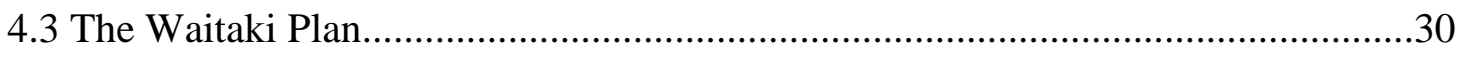

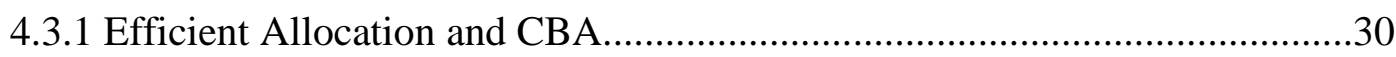


4.3.2 Adequacy and Accuracy of the Data the Plan is Based Upon.......................31

4.3.3 How Robust are the Objectives of the Plan?....................................................34

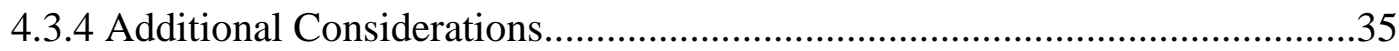

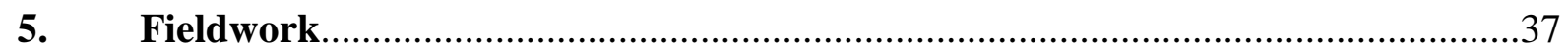

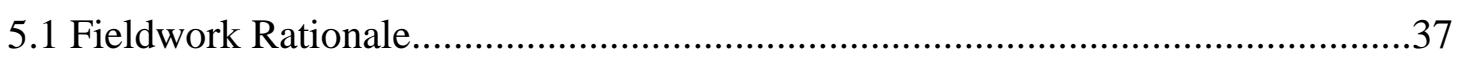

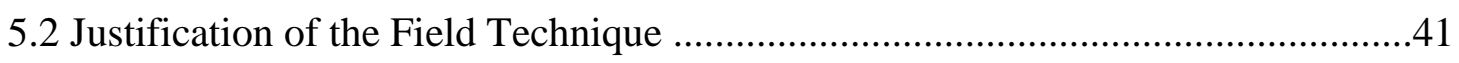

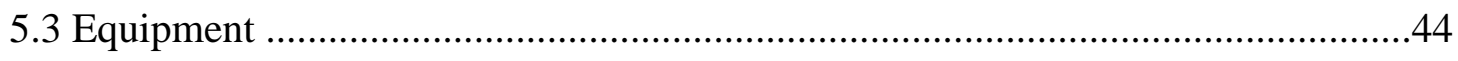

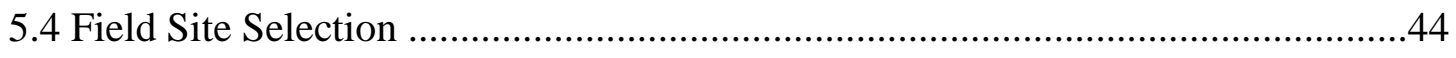

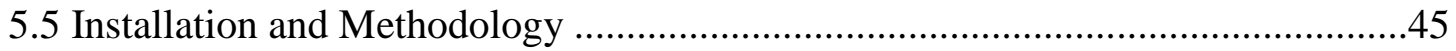

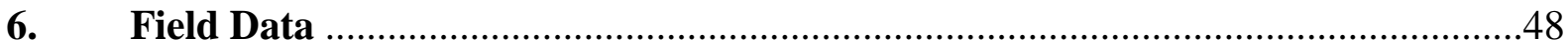

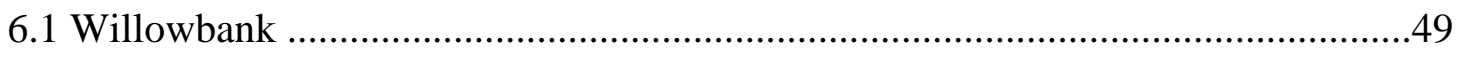

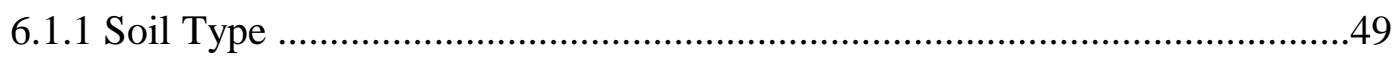

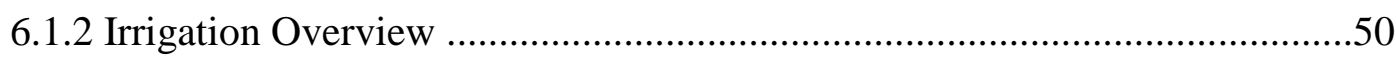

6.1.3 Individual Depth Profiles ....................................................................51

6.1.4 Willowbank Summary of Soil Response ..................................................54

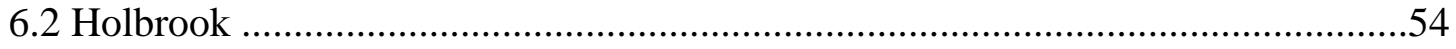

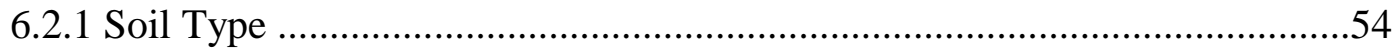

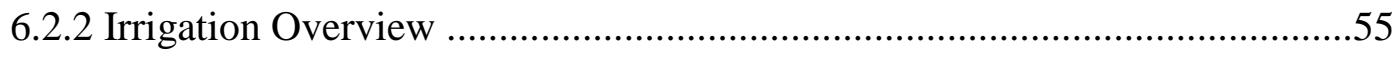

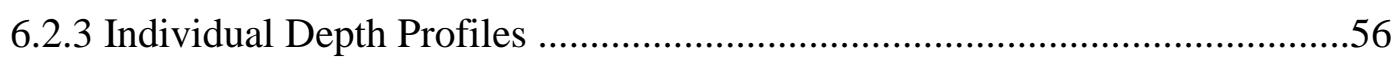

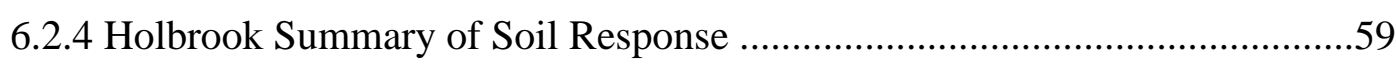

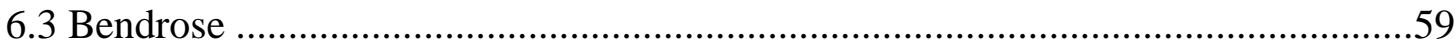

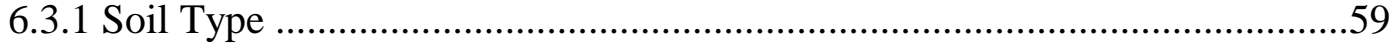

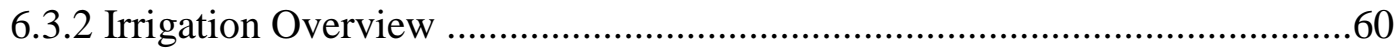

6.3.3 Individual Depth Profiles ..........................................................................61

6.3.4 Bendrose Summary of Soil Response ...................................................63

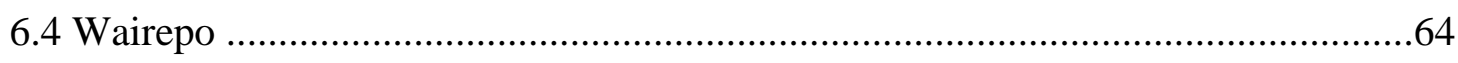

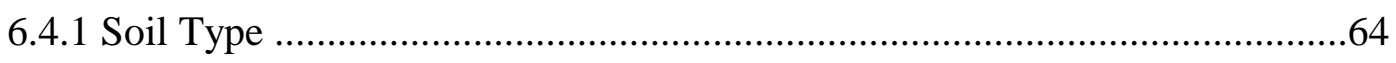

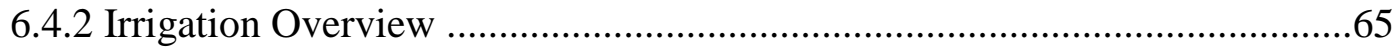

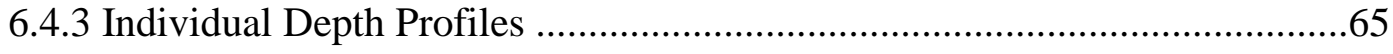

6.4.4 Wairepo Summary of Soil Response ........................................................69

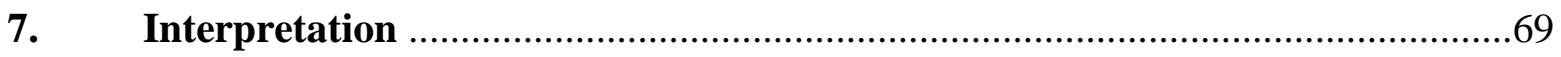

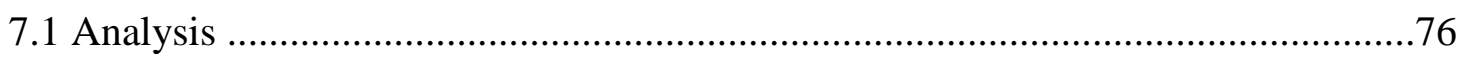

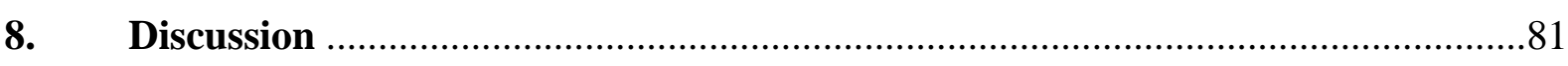

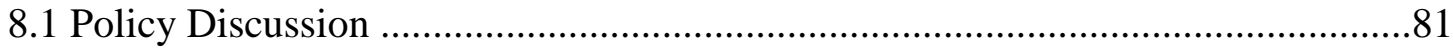

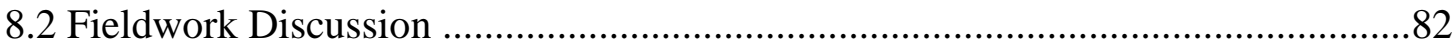




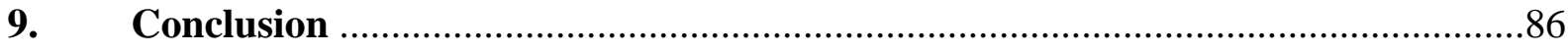

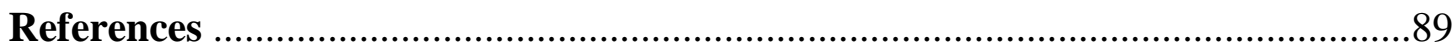

Appendix A. Soils of the Upper Waitaki Basin- NZSC ............................................96

Appendix B. Soil Series of the Upper Waitaki Basin ................................................97

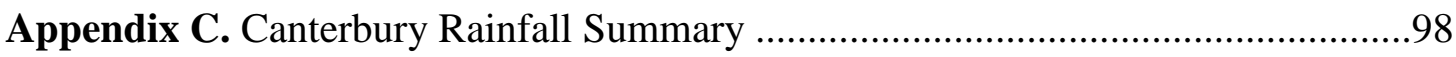

Appendix D. Timeline Showing Key Legislation ...................................................99

\section{List of Figures}

Fig. $1.1 \ldots \ldots \ldots$ Regional weekly water allocation for irrigation ..........................................

Fig. 2.1 ........Map showing Waitaki sub-catchment divisions ........................................... 8

Fig. 2.2 ........The waters of Pukaki canal with Aoraki in the background ...........................9

Fig. 2.3 ......... Categories in the New Zealand soil classification .........................................12

Fig. 2.4 ........Rainfall regions and annual rainfall records for the upper Waitaki ................14

Fig. 2.5 ........Rainfall and temperature averages for Lake Tekapo ...................................15

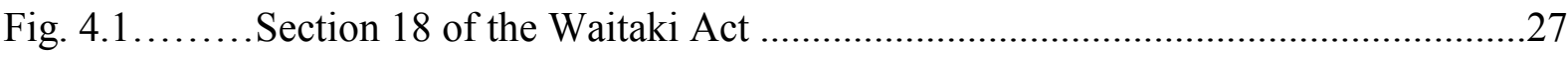

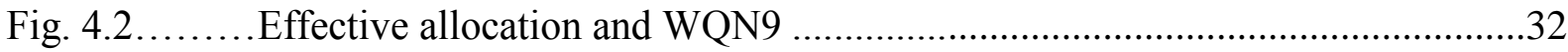

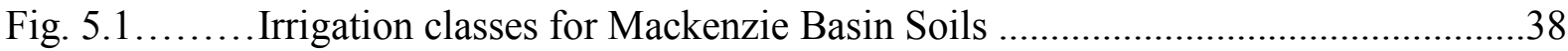

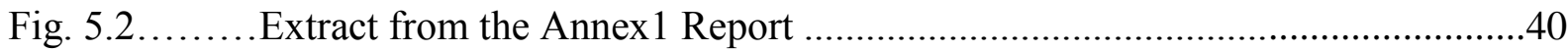

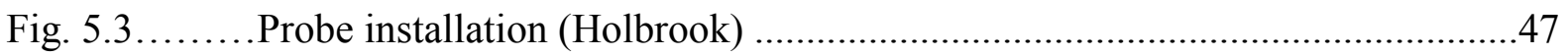

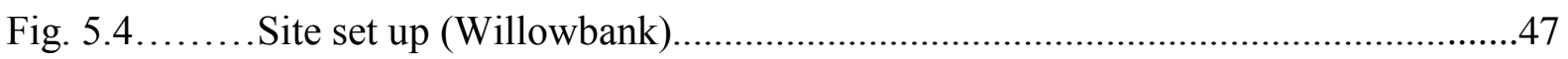

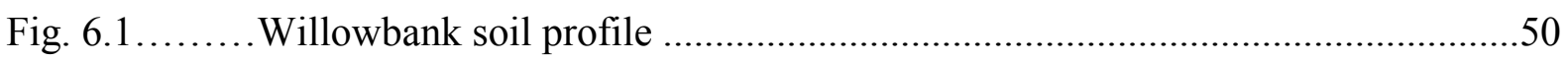

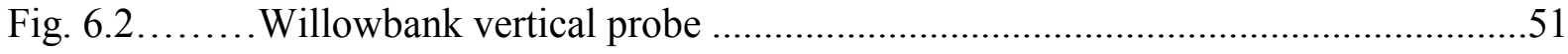

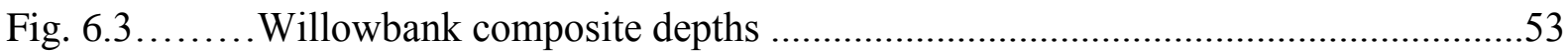

Fig. $6.4 \ldots \ldots \ldots$ Willowbank total profile moisture average as a percentage ..........................53

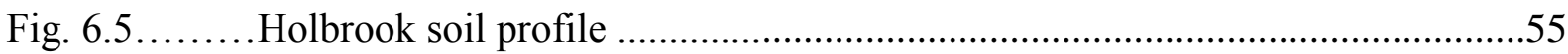

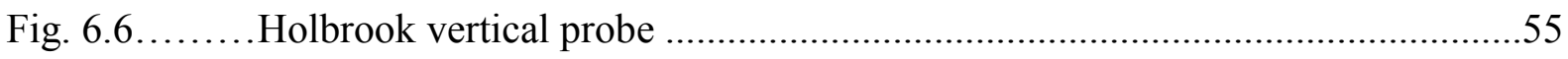

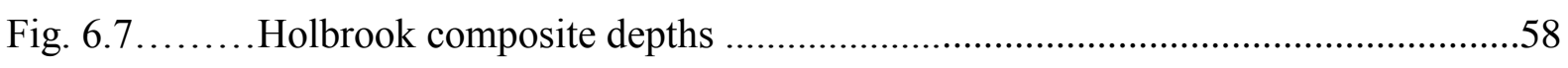

Fig. $6.8 \ldots . . .$. Holbrook total profile moisture average as a percentage...............................58

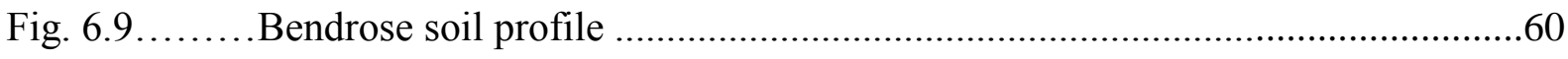

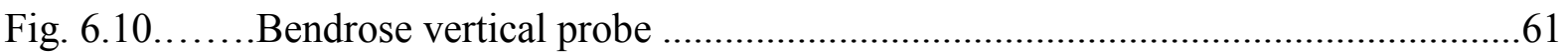

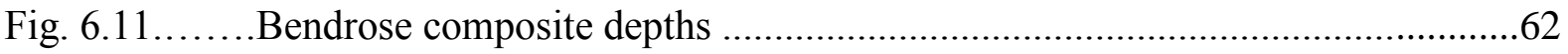

Fig. $6.12 \ldots \ldots . .$. Bendrose total profile moisture average as a percentage .............................63 


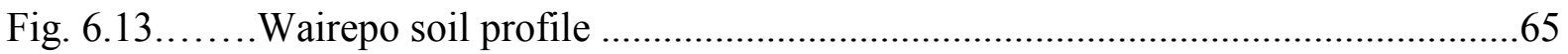

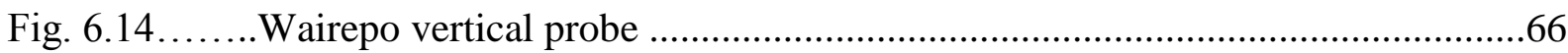

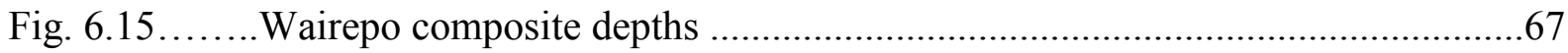

Fig. $6.16 \ldots \ldots .$. Wairepo total profile moisture average as a percentage ................................67

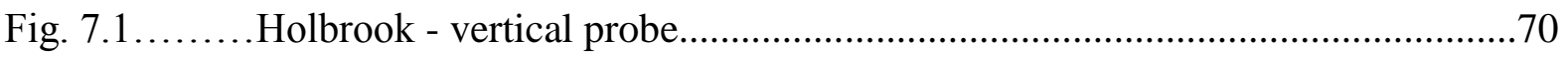

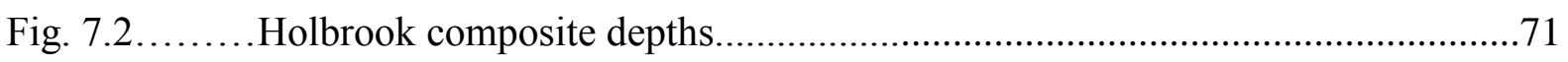

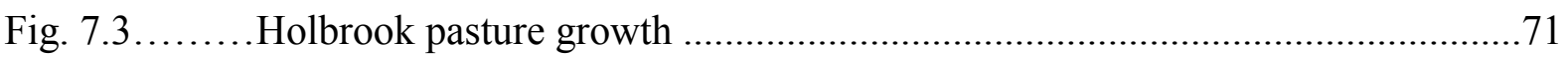

Fig. 7.4 .......Willowbank - average profile moisture ................................................... 72

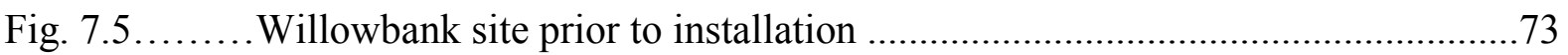

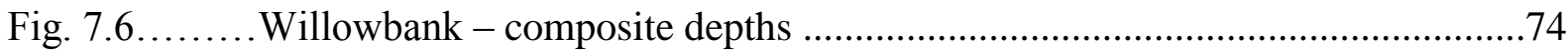

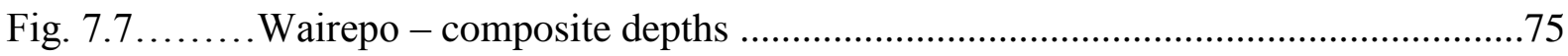

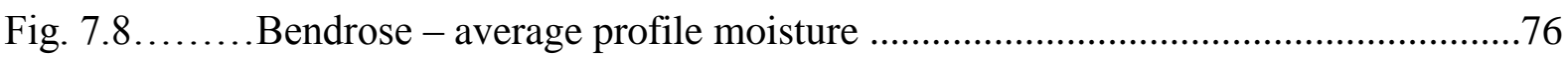

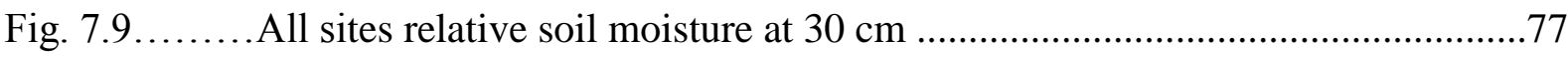

Fig. 7.10 .........Willowbank and Holbrook vertical soil moisture ........................................78

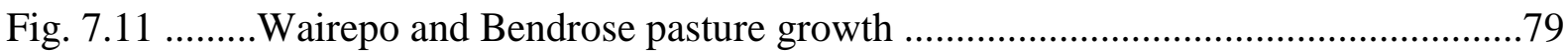

Fig. 7.12 ..........Composite depth graph; Bendrose and Wairepo ..........................................79

\section{Tables}

Table $1 \quad$ Clay percentage at depth for each field site .43

Table 2 Summary of individual site irrigation data 


\section{Chapter 1 - Introduction}

Dairying is an important industry to the New Zealand economy. Though it comprises just $4.8 \%$ of GDP, it is the largest export earner accounting for $21 \%$ of total exports and valued at 7.5 billion NZD. This makes it a major contributor to the country's terms of trade and balance of payments (Stats NZ, 2008).

In recent years the dairy industry has been intensifying and expanding at an ever-increasing rate (PCE, 2004; MAF, 2006b), and this has been accompanied by an upward trend in the value of dairy commodities ${ }^{1}$ (Agri-Fax, 2007). This in turn has influenced the traditional farm structure from an owner-operator business to an increasingly corporate enterprise, with equity partnerships providing high rates of investment and expecting high rates of return (Dairy Holdings Inc, 2008; Mulet-Marquis et al., 2008; Payne et al., 2007).

This intensification is illustrated by comparing stocking rates versus land use area. Whereas in 1994 there were 3.8 million dairy cattle grazing on 13.5 million/ha, by 2004 that had become 5.2 million cattle grazing on just 11.7 million/ha (Stats NZ, 2008). In the South Island dairy cattle numbers increased 24\% in five years, from 1.3 million in 2002 to 1.6 million in 2007 and the region contributing most to that increase was Canterbury (up 39\%).

The expansion of the dairy industry is shown in the rate of farms converting from dry-land arable farming to water intensive dairying (MAF, 2001). According to the Pastoral Monitoring Report (MAF, 2007), the Canterbury Region had thirty conversions in the 2006/07 season and forty planned to convert in the 2007/08 season. However, it noted that, "water continues to be a major issue for the Region" (MAF, 2007: 57).

As farms have become more intensive and increasingly occur on marginal land, external inputs to the farming system have similarly increased (PCE, 2004). This includes feed supplements, nitrogen based fertilisers and in drier regions such as Canterbury, an increase in irrigation (Aqualinc, 2006a).

\footnotetext{
${ }^{1}$ With record payouts for the $2007 / 08$ season of $\$ 7.90$ per kg MS (www.ruralnews.co.nz) compared to $\$ 3.75$ in 2002/03 (Agrifax 2007)
} 
Figure 1.1 shows the comparison of weekly allocation of 14 councils for both ground and surface waters for irrigation. Canterbury and Otago are plotted separately because their allocation volumes are several orders of magnitude greater than other regions. Canterbury in particular shows a large increase $\left(48 \%\right.$ ) from $250 \mathrm{~m}^{3} / \mathrm{s}$ in 1999 to $370 \mathrm{~m}^{3} / \mathrm{s}$ in 2006 (Aqualinc, 2006a).
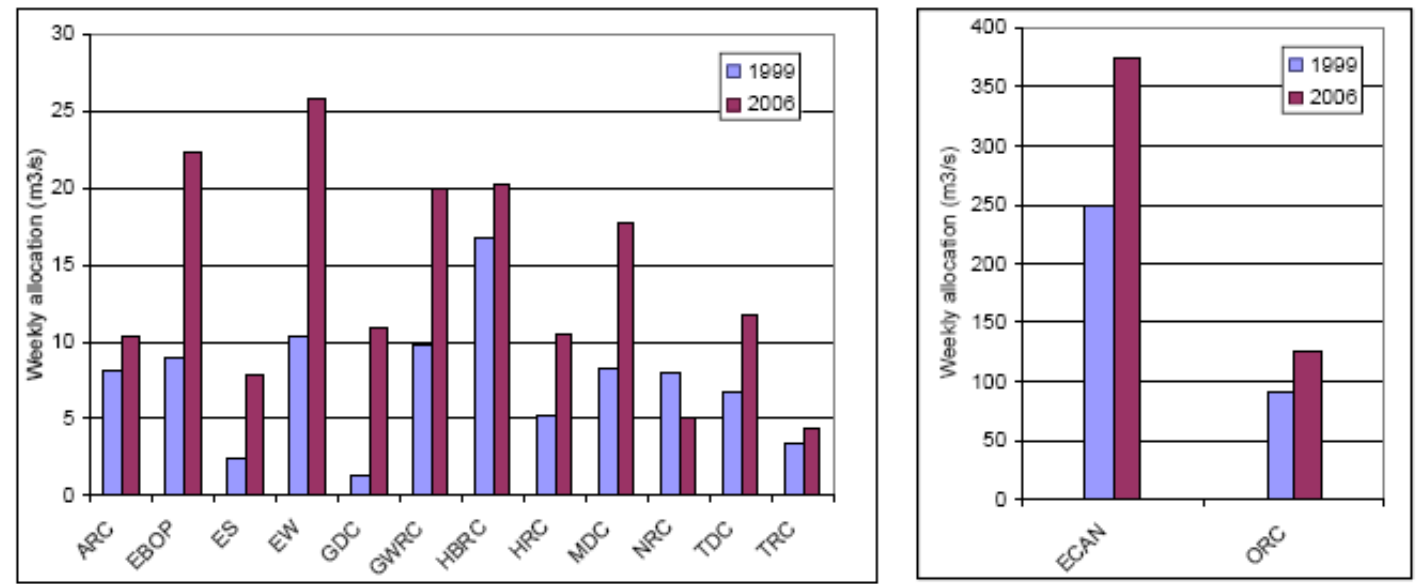

Figure 1.1; Regional weekly water allocation for irrigation in $\left(\mathrm{m}^{3} / \mathrm{s}\right)$ from1999 and 2006 (Aqualinc, 2006a)

In total, national water allocation doubled between 1999 and 2006 and irrigation is by far the largest consumer of that water (Aqualinc, 2006b). In 2006, 77\% of all abstractive water consents were for irrigation and, of all the water allocated to irrigation in New Zealand, over $58 \%$ is allocated in Canterbury (Aqualinc, 2008; Lincoln Environmental, 2002). Clearly the demand for water is increasing (particularly in drier regions) but what impact is this having on the quality of our natural resources and what are the implications if that trend continues?

The 2007 Environment New Zealand report states that agriculture has had the most widespread impact on water quality and this impact has grown as a result of higher intensity land use, increased stocking rates and use of nitrogen fertilisers. Indeed the rivers/lakes identified as being the most nutrient enriched are also those whose catchments contain highdensity dairying areas (MfE, 2007).

This indicates that farming practice is responsible for the changes seen in water quality, including elevated nitrate levels (39\% of all groundwater monitoring sites show levels above normal background), bacterial contamination (25\% of the 230 monitored sites tested noncompliant for E.coli indicating they are not suitable for swimming) and eutrophication of lakes (75 of the 134 lakes monitored have 'high to very high levels of nutrients') (MfE, 2007:279). 
This trend in water quality has been increasingly recognised and the frameworks aimed at countering it make use of both voluntary and regulatory mechanisms. An example of a voluntary mechanism is the use of on-farm nutrient budgeting as detailed by the Dairying and Clean Streams Accord (Fonterra Co-operative Group, 2003). This is aimed at reducing levels of nutrient application. However, surveys indicate that while the development of nutrient budgets is increasing, the application of those budgets is not universal (MAF, 2006a). An example of a regulatory mechanism is the requirement of a consent for dairy farm effluent disposal, with compliance monitored by Regional Councils. However, annual monitoring reports from Regional Councils indicate compliance is nationally variable, exemplified by the $60 \%$ non-compliance recorded in Canterbury for the 2006/07 season (Thompson, 2007). In spite of these various mechanisms water quality in New Zealand lowland rivers decreased between 1997 and 2007 (MfE, 2007). Clearly then, we are failing to protect our water bodies.

When discussing water quality the issue of water quantity must go hand in hand. When exploring the question of sustainability they cannot be addressed as separate issues but as an interrelated whole. Water quantity directly impacts water quality as a reduction in the first decreases the ability of the hydrological system to deal with inputs (pollutants) thereby reducing the second.

In New Zealand, Regional Councils administer water allocation via resource consents as part of the responsibilities devolved to them under the Resource Management Act 1991. They are guided in this process by regional policy statements drafted by individual Councils and, in theory, by national policy statements and national environmental standards - which, it is fair to say, have been slow in coming. Under the RMA resource consents are also allocated on a 'first in, first served' basis (Milne, 2003). This is increasingly inadequate as catchments become fully allocated and competing demands on water escalate. This particular issue came to prominence in the Waitaki Catchment in 2003 when several large applications for water were lodged in conjunction and it quickly became apparent there was not enough water to fulfil the demand.

The Government subsequently announced a Ministerial call-in of all pending consents, and then announced new legislation enabling a specific catchment plan to be developed to address the issues of allocation priority while protecting in-stream values. The Resource Management Waitaki Catchment Amendment Act was passed in 2004, and, in accordance with the statute a Regional Plan was drafted and passed in 2006. This is unique legislation in New Zealand. 
Pertaining to a single catchment, it had the potential to serve as a template for a management tool, and address the issues surrounding water quality and quantity evident in a majority of catchments throughout the country. However, the Plan deals only with allocation to water takes; discharges remain governed by the draft Natural Resources Regional Plan currently being compiled by the Canterbury Regional Council (CRC). This is the framework that the Council now finds itself working within and it is currently hearing consents relating to dairy farms (both conversions and intensification of existing farms) regarding water allocation and dairy farm effluent disposal.

In the upper Waitaki Basin the change from dryland sheep farming to intensive dairying has been rapid, and has had noticeable impact on the amenity value and character of the area (Densem, 2004). Given the impact intensive dairying has had on other catchments it seems counterintuitive that the same industry could be introduced with no additional mechanisms to ensure these same effects are not visited upon this area. Thus, a closer look at aspects surrounding the expansion of the dairy industry in this area is warranted.

\subsection{Aim}

The aim of this thesis is to question the sustainability of dairying in the Upper Waitaki Basin in terms of water allocation and use. In other words it will examine whether dairying is the "best use" of that resource in that area, from both an economic and environmental perspective. It will question the sensibility of removing a resource from hydroelectric generation and allocating it to agriculture while nationally attempts to address climate change falter and international commitments loom. It will the sustainability of dairying by conducting a policy evaluation and in so doing consider the efficiency of water allocation in the area. It will then consider the potential impacts of intensive irrigation on the natural resources of the area and discuss the implications both immediate and long-term. 


\subsection{Scope}

A discussion of sustainability is necessarily complex, governed as it is by even the most basic of definitions - as incorporating economic, environmental and social systems. In a paper on sustainable development, Sinner et al. (2005) highlight this systems view and stress that these are interrelated, overlapping concepts of the 'real system' and therefore there is a need for integrative research that crosses "traditional disciplinary and sectoral boundaries" (my emphasis; Sinner et al., 2005:2).

This thesis, in addressing sustainability, necessarily crosses disciplinary boundaries. Aspects of economics are incorporated with an analysis of policy and reviews of cost-benefit analyses. Environmental systems are studied using hydrological techniques and social systems are represented in the consideration of historical claims to water amenity values and the local versus national benefit debate. This holistic approach is limited only by the depth to which each facet of information can be examined within the constraints of the thesis.

With that in mind, the sustainability of dairying is considered only in terms of water inputs; specifically the efficiency of allocation and use, as well as the long-term and cumulative effects to the surrounding natural resources. The sustainability of dairying will be measured against whether it is the most economically efficient use for water in that region and whether using the precautionary principle there are likely to be long-term environmental impacts. It will not consider other inputs or make comparisons with other areas. The thesis will not explore the definition of sustainability beyond the basic tenet of comprising the three elements commonly attributed to it - that of environmental, economic and, social and cultural aspects $^{2}$.

\subsection{Objectives}

Meeting the aim requires several specific objectives. To meet the objectives requires two distinct approaches: one approach encompasses aspects of economics and environmental

\footnotetext{
${ }^{2}$ For a good discussion on sustainability see Bosselmann (1991) and Ehrenfeld (2005); and for a through discussion of irrigation efficiency see Aqualinc (2006b)
} 
policy (qualitative); the other incorporates a hydrological focus within the discipline of physical geography (quantitative).

The objectives are:

- Review the development of the region in terms of the competing users of water, hydro-generation and agriculture, and their historical claims to water.

- Assess the legislation surrounding water allocation and its impact on water use efficiency.

- Conduct field research to highlight varying soil response to irrigation under differing land use

- Explore the potential impacts on natural resources from intensive irrigation.

\subsection{Structure and Method}

The structure of the thesis is designed to introduce and explore the issues influencing the sustainability of dairying in this region. With that in mind,

- Chapter 2 provides an introduction to the Upper Waitaki Basin - its geomorphology, resources and physical setting.

- Chapter 3 introduces the human aspect of development, and the twin industries of hydro-generation and agriculture are explored within the legislative framework.

- Chapter 4 examines the unique legislation surrounding this area and provides a critique on several points.

- Chapter 5 discusses the rationale for conducting the fieldwork, the technique used, its theory and methodology.

- Chapter 6 presents the fieldwork data and Chapter 7 provides an interpretation of what they imply.

- Chapters 8 and 9 provide a discussion and conclusion respectively. 


\section{Chapter 2 - Study Area}

\subsection{Introduction}

The upper Waitaki Basin is located in the centre of the South Island, adjacent to and east of the Southern Alps. The Basin contains catchments of four rivers, Tekapo, Pukaki, Ohau and Ahuriri, of which the Ahuriri has a 1990 National Water Conservation Order placed on it. The four rivers converge at Lake Benmore and together form the Waitaki River. For the purposes of this thesis the Waitaki Basin comprises that area identified as "upper catchment tributaries", "Ahuriri Catchment" and "tributaries to the glacial lakes" in figure 2.1. The Waitaki catchment falls within the jurisdiction of Canterbury Regional Council (brand name, Environment Canterbury or ECan), as part of the South Canterbury constituency.

\subsubsection{Geomorphology}

The Basin has an average elevation of approximately $600 \mathrm{~m}$ a.s.l consisting of hilly to flat land, bounded in the south, east and west by mountain ranges and in the north by Lakes Tekapo, and Pukaki. The geomorphology is strongly defined by glacial landforms including the post-glacial lakes of Ohau, Pukaki and Tekapo, impounded by hummocky moraines. It contains extensive outwash plains and braided riverbeds with associated terraces, of varying ages, surrounded by coalescing fans on the basin margins (Cox, et al., 2007).

\subsubsection{Industry}

The area has a robust tourism industry (Leisure Matters, 2004; Wilson et al., 2006), is the largest provider of hydroelectricity generation per catchment, producing $33 \%$ of New Zealand's total GWh per annum (MfE, 2004a) and is seeing an increasing conversion of dry land sheep farming to irrigation intensive dairying (field observation). 


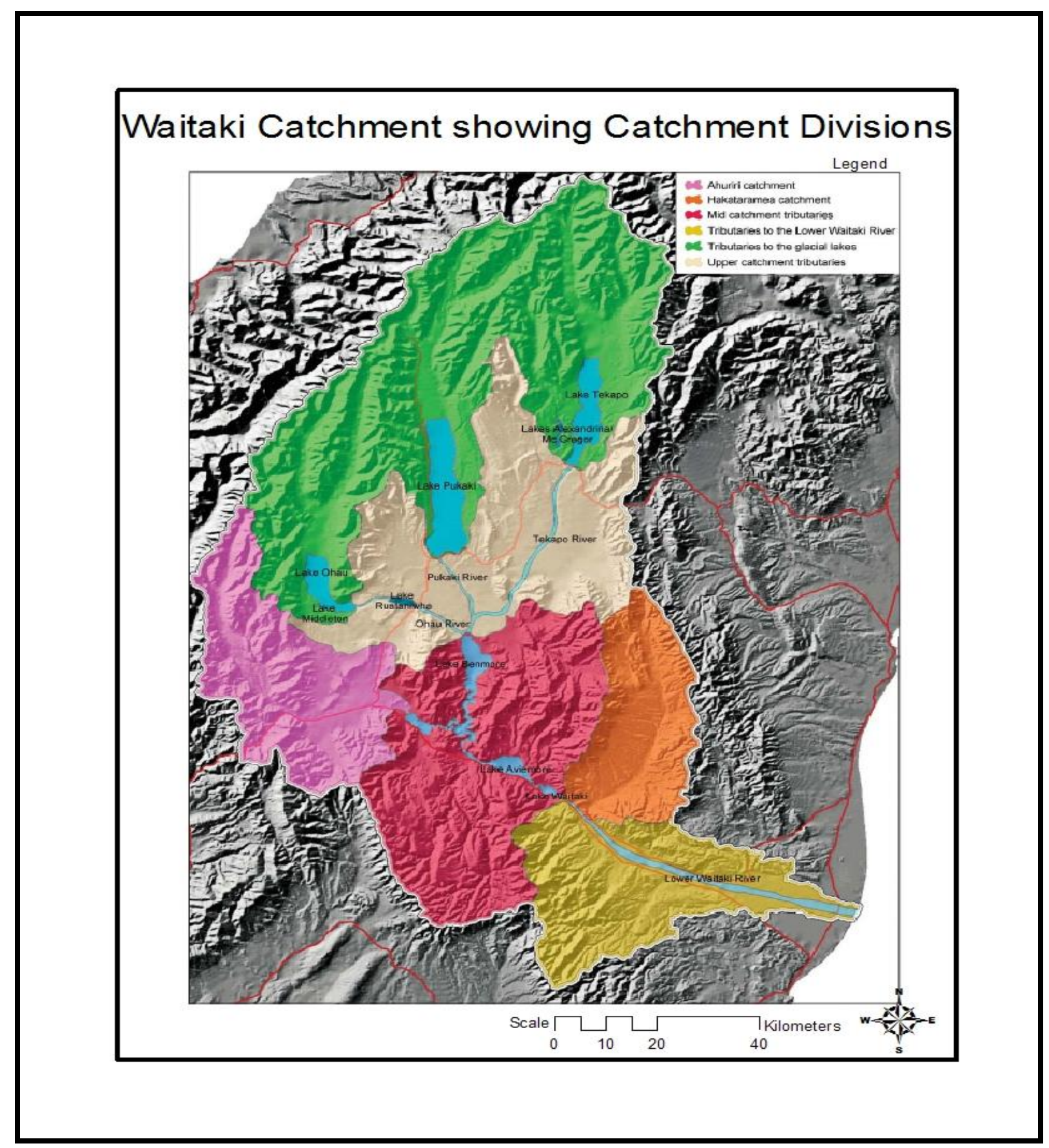

Figure 2.1: Waitaki Catchment, showing division of sub-catchment areas from the Waitaki Catchment Water allocation Board (WCWARP, 2006).

\subsubsection{Visual Amenity Value}

The catchment has been described in a report from Boffa Miskell as being a vast open landscape where landforms are often huge and vistas are wide and uncluttered (Brown, et al., 2005). A Canterbury Regional Landscape Study in 1993 identified the Upper Waitaki as regionally "outstanding" and/ or "significant" according to the criteria determined by the Environment Court. However, the findings of the study, though commissioned by them, were not formally adopted by Environment Canterbury in its Regional Policy Statement (Densem, 
2004). ECan is currently reviewing the Canterbury Regional Policy Statement (CRPS) as part of the statutory requirement under the RMA. This will include a review of the 1993 landscape study although as of January 2008 they were calling for tenders to conduct an additional study. It is important to note that the CRPS is an overarching policy document and both district and regional plans must give effect to it once operational. This would then have implications for development proposals that would change the intrinsic nature of the landscape, including the replacement of tussock grasslands with the lush pasture associated with dairying.

Additionally a report commissioned by the Waitaki District Council in 2004 declared the landscape to have "strong scenic values of grandeur, openness and naturalness, with many areas likely to qualify as outstanding or significant" under s.6 of the RMA (Densem, 2004:22). The report described the area as being characterised by turquoise lakes bordered by sere coloured tussock/grasslands and surrounded by towering snow-capped mountains, as illustrated from the photo below (Figure 2.2).

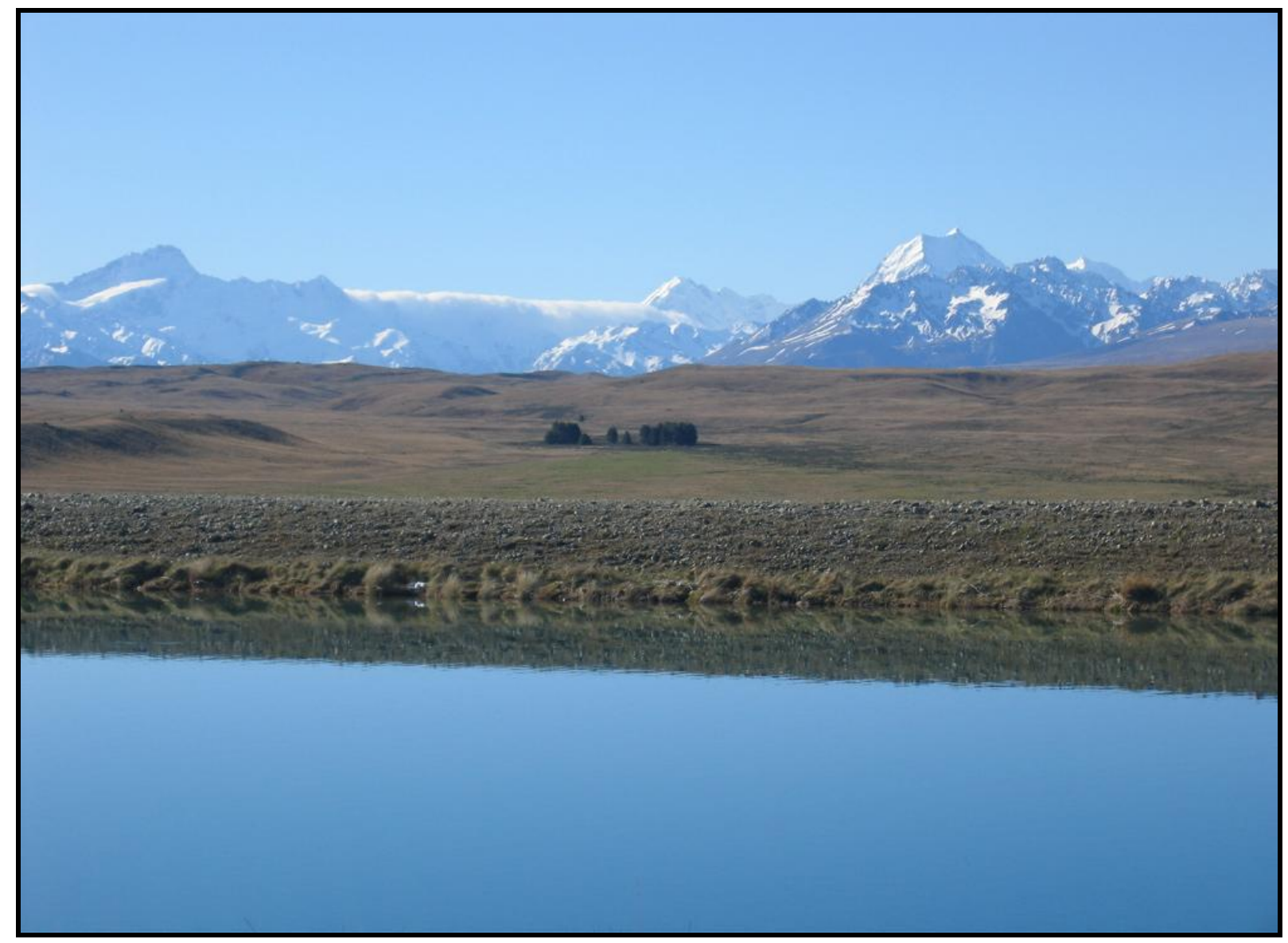

Figure 2.2. The waters of Pukaki canal bordered by tussock grasslands, with Aoraki, Mt.Cook in the background. 


\subsection{Geology}

The aim of this section is to provide an understanding of the genesis and structural history of the rocks that provide the parent material of soils; this in turn gives a broad indication of the resulting soils and their expected response to water application and retention.

The basement rock of the upper Waitaki Basin is comprised of metamorphosed sedimentary sandstones and mudstones that together make up the Rakaia Terrane, and form part of the Torlesse Super-group (Cox et al., 2007). This sequence, of predominantly quartzofeldspathic origin, was deposited in the margins of Gondwana during the Carboniferous through to the Early Cretaceous and is commonly referred to as Greywacke (Mildenhall, 2001).

Following accretion of these sediments to the Gondwana supercontinent, the New Zealand region began to separate in the late Early Cretaceous, and the area that would eventually contain the Waitaki Basin underwent erosion and subsidence. This led to the formation of a broad erosional surface known as the Waipounamu Erosion Surface, remnants of which can be seen in the Rolleston Range bordering the north east of the Basin (Cox et al., 2007).

The Australian-Pacific plate boundary developed during the Neogene (23ma) and subsidence continued in the far east only, illustrated by the eastward prograding wedges of sediment interspersed with marine deposits of the plains. Toward the end of the Miocene (5ma), a change in plate movement created an obliquely convergent plate collision. The rocks comprising the Torlesse Group were further structurally deformed and uplifted to form the hanging wall of the Alpine Fault; a continuation of the phase of mountain building known as the Kaikoura Orogeny. Adjacent folding and faulting led to the formation of the Canterbury basin and range topography seen today (Cox et al., 2007).

The uplift associated with boundary development and movement both formed and stripped much of the older Tertiary formations of the Basin. Remnants occur as isolated outcrops, such as the well known "clay cliffs" (Glentanner Formation) to the west of Omarama, although most are buried under the plains deposits. These Tertiary formations are predominantly piedmont fan sequences and consist of gravels with accompanying freshwater lacustrine beds (Mildenhall, 2001). 
Surface Basin sediments predominantly contain Pleistocene and Holocene deposits of till, fluvio-glacial outwash, fans, and wind blown loess. These have been deposited by a series of ice advances and recessions, as shown by both degradational and depositional processes evident in the sedimentology. There have been four main ice advances identified. In ascending order of age they are, Wolds (135 000 years BP), Balmoral (60 000 years BP), Mount John (25 000 - 18000 years BP) and Tekapo Formations (15 000 - 12000 years BP) (Bell, 2008; Webb, 1992). Fan formation within the Basin post-dates the glacial deposits with the youngest fans cutting into or supine to the Tekapo Formations (Cox et al., 2007).

The modern landscape, then, is dominated by the uplifted mountains of the Southern Alps to the north and west, and the immediately adjacent post-glacial lakes of Ohau, Pukaki, and Tekapo. These in turn are bound by hummocky moraines - reflecting ice sheet deposition, grading into gently southeast sloping outwash terraces and plains, which are cut in turn by braided river systems. There also exists additional alluvial fan development on the east, south, and western hill country margins from the result of uplift (Molloy, 1993). What can be inferred from this, in terms of soil development, is that the soils are derived from fluvioglacially deposited gravels and glacial tills; are likely to have shallow A and B horizons (given the limited time for development) and be freely draining. Details on groundwater in the area are sparse for the upper catchment but it is generally considered to be shallow, with one report stating depth to groundwater can vary from, at or near surface, to a depth of 30 metres on the higher terraces, within the length of the same aquifer (SKM, 2004b).

\subsection{Soils}

This section will briefly review soil classification in New Zealand, followed by a discussion of the soils in the upper Waitaki.

\subsubsection{Soil Classification in New Zealand}

Soil formation is influenced by five major contributing factors - parent material and relief (as discussed in the previous section), climate, organisms and time (White, 2000; Lynn et al., 2002). Early classification systems recognised the importance of parent material and climate, in particular, on soil formation and based their classification on these soil-forming processes. 
However, later classification systems also incorporated measurable or observable properties, such as salinity and $\mathrm{pH}$ as classification parameters. The New Zealand Soil Classification (NZSC) developed in 1992 by Hewitt is such a system (Appendix A) (McLaren et el., 1998).

The NZSC is the classification system used for all published soil survey data including the Landcare Research database - New Zealand Land Resources Information (NZLRI). Though the NZSC operates on a hierarchal system consisting of orders, groups, sub-groups, a unit known as the soil series is often used for aligning broadly similar taxonomic groups in greater detail (Fig. 2.3). Current published maps on the soils of the upper Waitaki use the series as the main map unit (Webb, 1992; 1997) (Appendix B).

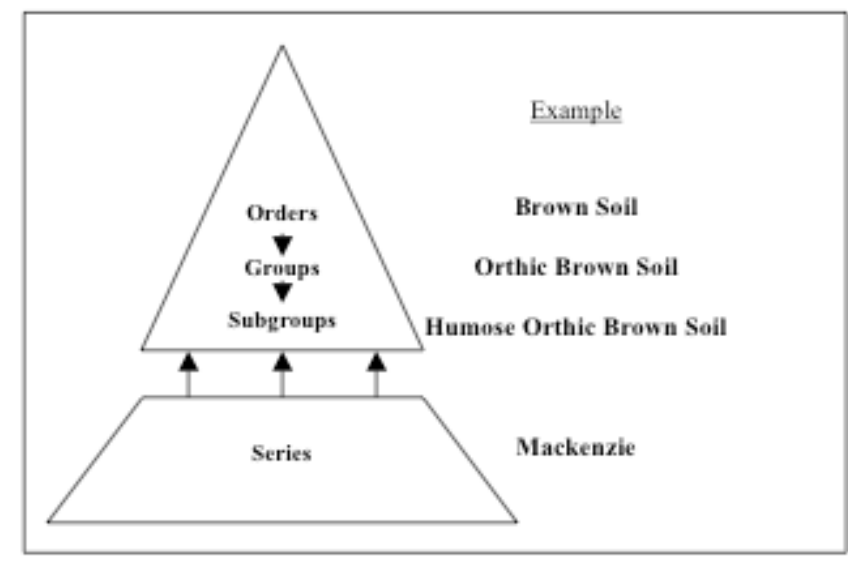

Figure 2.3: Categories in the New Zealand Soil Classification (McLaren et al., 1998)

\subsubsection{Soils of the Upper Waitaki}

In the upper Waitaki the majority of observed new irrigation development occurs on soils classified as Brown (order), Orthic (group), Humose (sub-group) soils (BOH) (Appendix A). The Brown soils are the most extensive of all New Zealand soils and are defined as having 2:1 clay minerals, with secondary iron oxides imparting a yellowish brown colour to the upper part of the B horizon (Hewitt, 1992). The group definition of Orthic goes on to define the soil as having B horizon peds (aggregates) or weak soil strength to depth and occurring on Holocene land surfaces, while the Humose sub-group delineates it on the basis of having both

1. colour value of the matrix 4 or less and hue $2.5 \mathrm{Y}$ or redder, or $10 \%$ or more coatings of colour value 4 or less in the greater part of the B horizon, and

2. $10 \%$ or less clay within $90 \mathrm{~cm}$ of the mineral soil surface (Hewitt, 1992). 
Soil development in the upper Waitaki has been identified as being influenced in particular by geomorphology (in turn influenced by time and parent rock) and climatic zonation (Webb, 1992). Soils in this region can be recognised as being formed on moraines (loess on till); as terrace soils, with three distinct ages of development old, intermediate and young (comprising alluvial sandy gravels); or as soils formed on coalescing apron fans (heterogeneous deposits of stones and fines with considerable spatial variation). The three climatic zones, humid, moist subhumid and dry subhumid regions (Fig. 2.4) impart further distinctive attributes to soil development. These are defined by Webb (1992) as follows:

"Soils in the dry subhumid region have a weakly developed structure, low levels of organic matter, olive brown subsoil colours and accumulation of clay in subsoils. Except for shallow and stony soils they have fraigipans and are weakly leached. The soils in the moist subhumid region are similar but lack distinct clay illuviation, have weak fragipan development and are more leached. The soils in the humid region have moderate levels of organic matter, moderately developed structure, yellowish brown subsoil colours and are strongly leached".

These two influences, geomorphology and climate, allow distinctions to be made within the NZSC so that for mapping purposes a greater detail of soil pattern and development can be identified, thus enabling the use of the soil series as the cartographic unit. Therefore, within the Basin, while the majority of soils are classed as Brown Orthic Humous, distinctions could be made for the purposes of fieldwork by using the soil series as the distinctive unit. There are 29 individual soil series identified in the Basin (Webb, 1987; 1992). Published soil maps at 1:50 000 often comprise 'associations' of these, which are based on a soil-landscape relationship (Webb, 1992; 1997). The fieldwork sites occurred on three series/associations including the Mackenzie series, the Simons/Currughmore series association, and the Pukaki series (Appendix B).

In summary the soils in the upper Waitaki Basin can be described as being formed from fluvio-glacially derived gravels with associated loess, of three broadly defined ages, being well to excessively well drained and with considerable variability of stoniness and depth. The specific soil series included in the field study will be discussed in greater detail in chapter 6 . 


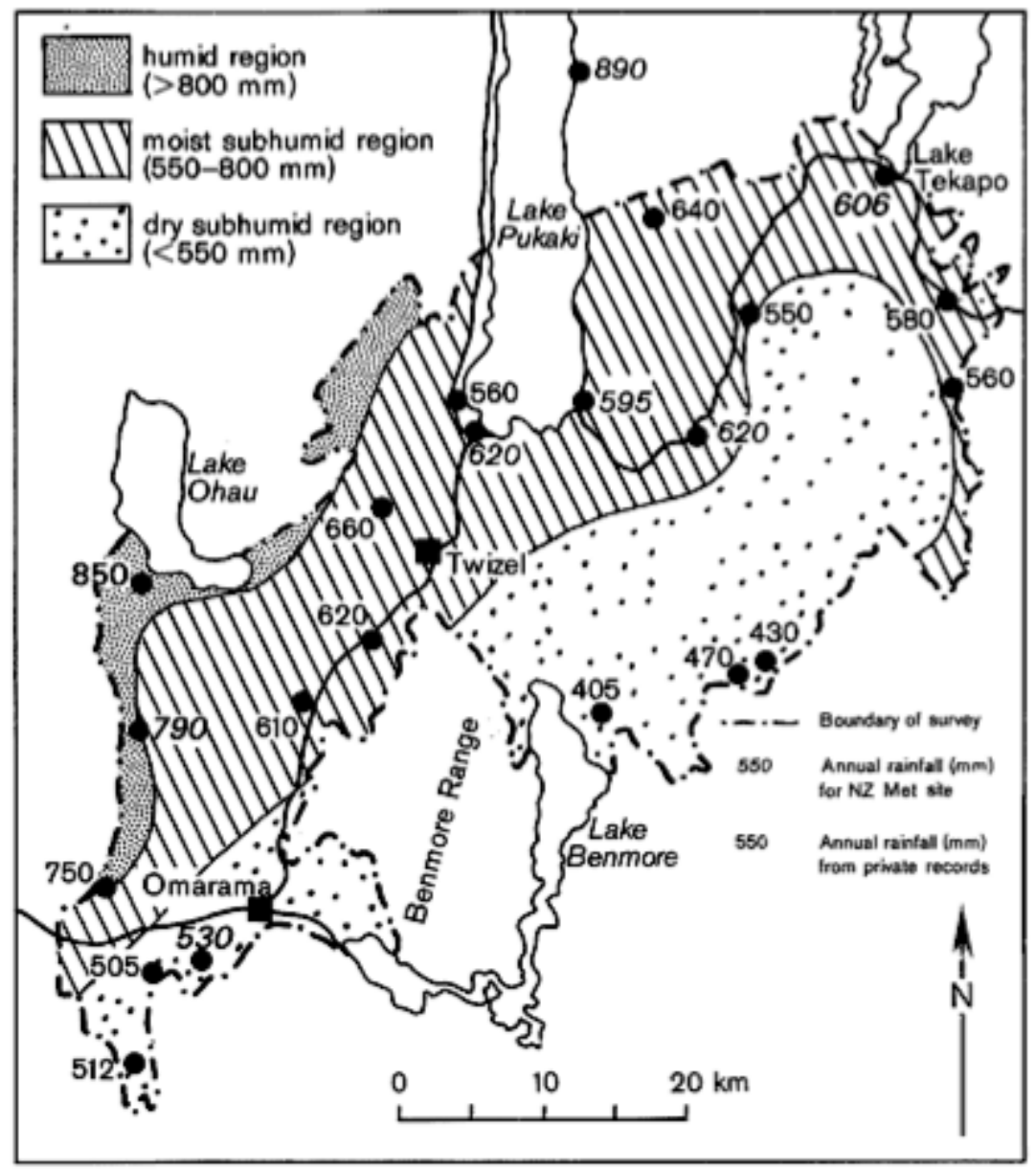

Figure 2.4 Rainfall regions and annual rainfall records for upper Waitaki Basin from Soils of the Upper Waitaki Basin, South Island, New Zealand (From Webb, 1992).

\subsection{Climate}

The basin experiences a sub-continental climate with generally hot dry summers and cold winters (Fig 2.5). The temperatures range from a mean maximum for January of $21.2{ }^{\circ} \mathrm{C}$ to a mean minimum of $-2.6{ }^{\circ} \mathrm{C}$ for July (though the coldest recorded temperature is $-15.6{ }^{\circ} \mathrm{C}$ ) (NIWA, 2008a). As well as a wide seasonal variation in temperature there is also a broad diurnal variation as nocturnal radiative cooling from the basin floor is accompanied by catabatic wind flow.

The predominant wind is from the northwest - a föhn created by the Southern Alps. This wind is a dominant feature of the Canterbury Region, responsible for depositing sediment but also recognised as being responsible for extensive topsoil loss and high rates of evapotranspiration. While other areas of New Zealand have relative humidity values of between $65-85 \%$ the Mackenzie Basin (of which some of the upper Waitaki Basin is a part of) often has values of $30-5 \%$. 
Additionally the highest wind gust ever recorded in New Zealand, of $250 \mathrm{~km} / \mathrm{h}$, was at Mt John (adjacent to Tekapo) in April 1970. The proximity of the Basin to the Southern Alps produces a rain shadow effect, evident by the strong precipitation gradient, with annual values ranging from $4293 \mathrm{~mm}$ at Mt Cook in the mountains of the northwest, to $<600 \mathrm{~mm}$ in parts of the basin floor (Appendix C).

During winter the average snowline is at or about $1000 \mathrm{~m}$, although snow on the basin floor is not uncommon. The biggest single fall of 1 metre occurred on November 211967 (NIWA, 2008b). Additionally there are on average 146 ground-frost days recorded per year with no months recognised as being entirely frost-free. All of the conditions described above, combine to give the upper catchment a shorter and relatively more difficult growing season as compared with locations lower down the catchment.

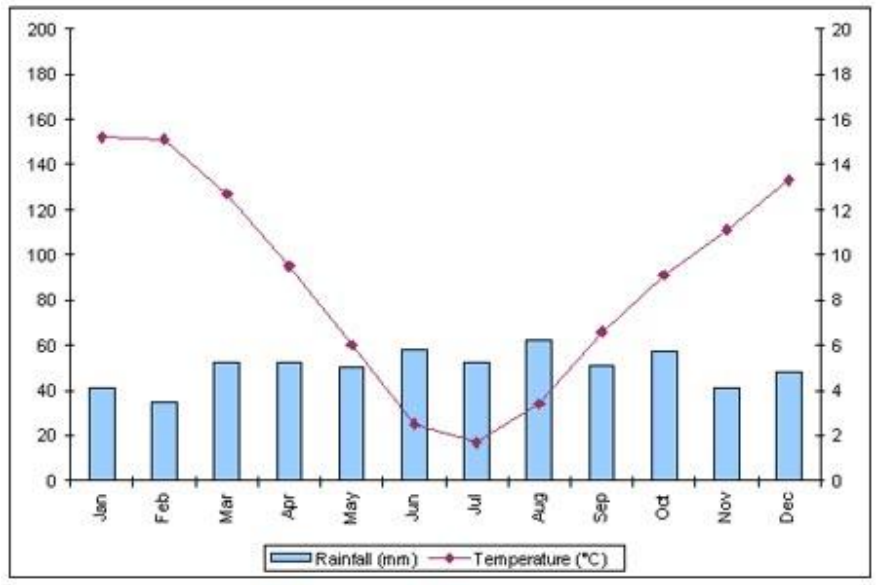

Figure 2.5 Rainfall and temperature averages for Lake Tekapo All climate data sourced from NIWA via http:/www niwa.cri.nz/edu/resources/climate for the period 1971-2000 (NIWA, 2008b)

This chapter has introduced the physical attributes of the Waitaki Basin, The aim of this was to acquaint the reader with its unique natural setting and to begin to explore some of the barriers to the long term sustainability of an industry requiring high rates of pasture production located on young thin soils underlain by shallow aquifers with an arguably extreme climate range. 


\section{Chapter 3 -Historical Legal Context}

This chapter provides background on the legislative history and development of both hydroelectric and irrigation infrastructure of the upper Waitaki. It illustrates the longevity of the dispute between competing users of water, highlights the roots of present day claims and reinforces how clear direction is needed for long term planning to enable sustainable resource use.

What emerges from the timeline is a pattern of hydroelectric development countered by requests from run holders for access to water, followed by negotiation then legal allocation, but little in the way of infrastructure development - until recently.

The first section (3.1) is based on a summary of the work carried out for the Ministry of Agriculture and Forestry (MAF) by Opus Consulting in 2004 on the 1969 Order in Council allowance for irrigation. The second section (3.2) goes on to discuss the influence of the 1991 Resource Management Act (RMA) and the development of the current legislative framework surrounding the Waitaki catchment (see Appendix D for a timeline of events).

\subsection{Orders in Council and Hydro-Generation Development}

The potential of the Waitaki River for hydroelectric generation was recognised by the Government as early as 1904 . However, it was not until the 1930s under a 'make work' scheme that the first dam and hydro station was built. Commissioned in 1935 the Waitaki Dam was constructed using picks, shovels and wheelbarrows (Meridian, 2007).

It was immediately apparent that the future power demand would exceed supply and in 1938 work on Tekapo A began. Halted by World War 2, it was finally commissioned in 1951. Benmore followed in 1964, along with a high voltage direct current link in 1965, enabling power transmission to the North Island (Investment NZ, 2006). 
During this time a body of concerned groups convened the Interdepartmental Committee on the Water Resources of the Mackenzie Basin ${ }^{3}$. Their aim was to investigate the feasibility of irrigation development in conjunction with hydroelectric development (Opus, 2004). In 1966 they released a report that was to be influential, both then and well into the future.

The 1966 Interdepartmental Committee Report, among other things, stated that a provision should be made for irrigation on the order of 11,000 acres by 1980 and up to 49,000 acres by the year 2000, though it noted at the time this was probably an "optimistic estimate of irrigation development" (Opus, 2004:7). The total figure estimated for annual allocation requirements was $172,687,430 \mathrm{~m}^{3}$ with a peak flow rate of 15 cumecs (Brown et al., 2005).

This figure resurfaces in recent history (Brown et al., 2005; WCWARP, 2006) in spite of advances in landuse capability assessment and a change in the type of irrigation proposed from that of supplementary feed for sheep and cattle to the intensive irrigation required for dairying.

In spite of (or perhaps pre-empted by) the influential Interdepartmental Report one piece of legislation in the late 1960s was to shift water allocation firmly into the sphere of the national interest rather than it remaining a local right only. This legislation was the 1967 Water and Soil Conservation Act (WSCA). This significantly changed the legal status of landholders regarding riparian rights. Whereas run holders had previously been treated as riparian owners, able to take and use water as required, the WSCA now introduced water as a Crown managed resource, with a system for the application and granting of water rights administered by Regional Water Boards (Milne, 2003). Further, and perhaps more importantly, under the same Act the waters of the upper Waitaki were declared, via a 1968 Order in Council, to be of national importance - including the waters flowing in artificial channels.

This firmly shifted the control and focus of the Waitaki waters toward the national interest. The rationale behind this was possibly due to the fourth power scheme - Aviemore (1968) nearing completion and government recognition of the long term importance of the Waitaki for hydro development with a subsequent need to ensure future generation capabilities (Opus, 2004).

\footnotetext{
${ }^{3}$ Instigated by requests from local landholders and Federated Farmers, the Committee included the Commissioner of Crown Lands - Christchurch, a Farm Advisory Officer - Agriculture Department, Investigating Engineer for Power Design - Ministry of Works (MOW) Wellington and the Resident Engineer MOW - Timaru, plus the District Commissioner of Works - Christchurch
} 
A further Order in Council in 1969 under the same act, granted the Minister of Electricity the right to 'dam, use, discharge, divert and take' water in the upper Waitaki for hydro-generation purposes. This granted to the Crown the rights for a period of 21 years, with successive right of renewal for ongoing periods of equivalent years. However, included within this 1969 Order in Council was a provision specifically for irrigation purposes of 15 cumecs over a 135-day season. The Minister of Electricity issued additional assurances, springing directly from the 1966 Interdepartmental Committee Report, in writing to the Waitaki Catchment Commission ${ }^{4}$. These included lump sum compensation for groundwater losses and promises of equivalent supplies with the capital costs of supply being borne by the Minister (Opus, 2004). However, details of how this would be implemented were scarce.

In 1977 a fifth station, Tekapo B was commissioned (Meridian, 2007). This was accompanied throughout the decade by several (1971 and 1976) landholder requests for irrigation feasibility studies in conjunction with hydroelectric development as promised by the 1969 Order in Council - particularly with a focus on outlet points from the canal system. However, a lack of projected immediate uptake acted as a deterrent to action and was countered by governmental requests for studies on actual 'near future' requirements (Opus, 2004).

By 1980 the Ohau A power station had been commissioned and by 1982 irrigation feasibility studies had realised three complimentary irrigation schemes totalling 11,000 ha on three stations. Additional irrigation outlets were incorporated into the Ohau B infrastructure, which came on line in 1984. The eighth power station, Ohau C, was commissioned in 1985, completing the current level of development, which includes 56 kilometres of canals (Meridian, 2007).

Clearly at this time irrigation infrastructure was finally beginning to be incorporated with hydroelectric development, as promised by the 1969 Order in Council. However, in the mid to late 1980s there was a major policy shift in New Zealand. This would have a lasting effect on agriculture particularly with regard to subsidies, including subsidies for irrigation development (Johnson, 1999; MAF, 2006b; PCE, 2004). Additionaly, part of that policy shift included the State Owned Enterprises Act 1986, which enabled the transfer of national assets to State Owned Enterprises. The subsequent 1988 Sale and Purchase Agreement of the water rights to the upper Waitaki from the Crown to the Electricity Corporation of New Zealand (ECNZ) is an example of that.

\footnotetext{
${ }^{4}$ The Regional Water Board responsible for administering the water rights (excluding those of the Crown)
} 
Almost immediately after the transfer, ECNZ would have had to renew its newly acquired water rights under the 1969 Order in Council (OIC) by 1990. Importantly, ECNZ elected to pursue renewal not through the OIC (with its inbuilt allocation to irrigation) but via the WSCA and by February 1991 the Canterbury Regional Council (CRC) had granted 63 water rights to ECNZ (IDG, 1998). This would have on-going ramifications for the continuing status of waters of national importance for the Waitaki.

This doubt about the status of the waters was further substantiated by an earlier 1988 amendment to the WSCA, which had repealed the ability to declare waters of national importance. While a special clause had upheld the 1969 OIC (right to dam, use etc), no mention was made of the 1968 OIC (waters of national importance), making its status questionable (Opus, 2004). Interestingly, in December 2004 a technical working paper was submitted to the Ministry for the Environment as part of the ongoing National Water Program of Action (WPoA), exploring potential water bodies of national importance. This project aims to identify nationally important values of water, and to protect and secure water bodies identified as containing those values from the pressures of land use change and intensification (MfE, 2004a). The Waitaki is listed in six out of the seven categories including energy (where it is ranked number one out of twenty-one for existing generation and number one out of ten for potential energy generation) and irrigation where it is ranked fourth in terms of existing contribution to farmgate GDP and second in terms of its potential (MfE, 2004a). As of writing, the WPoA has not implemented the findings of the report.

Back to 1988, and the transfer process to ECNZ had, at the time, also cast doubt on the validity of the allocation to irrigation contained in the 1969 Order in Council. The decision to pursue renewal of water rights under the WSCA had potentially further undermined the validity of the allocation. However, the renewal of the water rights was considered by Local Government and the farming community alike as a prime opportunity to renegotiate the allocation of water to other users (Opus, 2004).

With this in mind, the Waitaki Working Party was established, consisting of twelve key stakeholders, including local and central government bodies ${ }^{5}$. A consultation process was

\footnotetext{
5 The working party consisted of ECNZ, Department of Conservation, South Canterbury Fish and Game, Ngai Tahu Trust Board, Benmore Irrigation Company Ltd, The New Zealand Canoeing Association Inc., Mackenzie District Council, Lower Waitaki Irrigation Co., Maerwhenua District Water Resource Co Ltd, Moorven Glenavy Ikiwai Irrigation co, Transit NZ, South Canterbury Branch Royal Forest and Bird Society and the New Zealand Salmon Anglers Association Inc (Opus 2004)
} 
initiated and in November 1990, the stakeholders settled on ten 'agreements', as additions to the water rights already issued by the Canterbury Regional Council (CRC) (IDG, 1998; MEL, 2003). Those 'water rights' subsequently became 'permits' under the provisions of the 1991 Resource Management Act (RMA) and expire on 30 April 2025. The 'agreements' settled upon by the stakeholders still stand and are upheld to the present day. This will be discussed further in chapter 4.

In summary, by the mid 1960s hydroelectric development in the upper Waitaki was well established with further development planned; with that came recognition from local landholders of the need to ensure adequate supplies for stock and domestic needs as well as ensuring the availability for expansion of irrigation in the future. The 1966 Interdepartmental Committee Report provided projections of irrigable areas and volumes that were to be influential in future plans and negotiations.

In 1968, the Minister for Energy had sought and obtained an Order in Council bestowing on the tributary waters of the Waitaki the status of 'waters of national importance'. A further Order in Council in 1969 granted the Minister for Energy the right to 'dam, use, discharge, divert and take' those waters for the purposes of generating electricity. These essentially changed the process of water right applications for landholders and placed on the waters of the Waitaki a national rather than local stakeholder importance. However, although the 1969 and 1968 Orders in Council had effectively transferred all water rights to the Minister of Electricity, the 1969 Order in Council had built into it (backed via written assurances to the Regional Water Board) a provision for an allocation of 15 cumecs to irrigation - costs to be borne by the Crown as compensation.

A pattern emerges of central government making an early attempt to devolve administration of water allocation to regional authorities, while simultaneously recognising the national importance of the upper Waitaki resources for electricity generation and ensuring access accordingly. This is partnered by landholder attempts to secure access themselves, particularly with regard to future development. However, in spite of government assurances there was limited infrastructure development, due in part to the perceived lack of demand, which the restructuring of the mid 1980s halted altogether. Further, the 1988 transfer of the upper Waitaki waters to ECNZ cast doubt over prior water right agreements between landholders and the Crown. These were renegotiated, via consultation with key stakeholders and culminated in agreements, which still stand in the present day. 
This section has reviewed the historical claims to water and the legislative history with which they were bound. The following section will chronicle the influence of the RMA and the recent legislation specific to this area in terms of water allocation.

\subsection{The 1991 Resource Management Act and the Resource Management (Waitaki Catchment) Amendment Act 2004}

In 1999, ECNZ split into three state owned enterprises (SOEs) and Meridian Energy Limited (Meridian) became the retailer/generator of the Waitaki Infrastructure, inheriting the resource consents issued by Canterbury Regional Council (CRC) for Lake Tekapo and tributary waters (Electricity Group, 2008). However, due to a poorly defined process at the time of transfer, these had been stated only as a maximum rate of take or use in cumecs and were arguably ambiguous (MEL, 2003 [15]). Consequently in March 2003 Aoraki Water Trust (an irrigation consortium) lodged applications with CRC to divert and take $9 \mathrm{M} \mathrm{m}^{3}$ of water per week from Lake Tekapo for irrigation purposes (Aoraki v Meridian, 2004 [13]).

Closely following their application for water consents, Aoraki Water Trust (with Timaru and Mackenzie District Council) applied to the High Court for a declaration that Aoraki's proposed water permits would not constrain CRC's statutory discretion to grant water permits to others, even though this may reduce the amount of water available to Meridian. And secondly that Meridian's existing consents would not affect the future Waitaki Water Allocation Board's discretionary power to allocate provision for other activities within the forthcoming regional plan, even though this may reduce the amount of water available to Meridian (Aoraki v Meridian, 2004 [20]).

At the same time, Meridian applied to the Environment Court seeking a declaration on the extent of its resource consents regarding the taking and use of the waters therein (MEL, 2003). In September 2003 the Environment Court clarified the extent of Meridians consents. The ruling essentially found Meridian was allocated more water than the mean annual flow provides and thus to satisfy the consents, according to the non-derogation principal, all of the water within Lake Tekapo was effectively physically allocated to them (Aoraki v Meridian, 2004 [15]). In addition the court ruled on the continuing validity of the 1969 Order in Council declaring it defunct on the basis that the legislation supporting it had been repealed by the 
RMA. (MEL, 2003 [33]). In spite of this, there would be repeated calls by local representatives for the allocation to irrigation contained within it to be upheld by the future Resource Management (Waitaki Catchment) Amendment Act (Hansard, 2004a). However, this had essentially already been achieved via the side agreements negotiated in 1990 between ECNZ and various stakeholders, which Meridian confirmed it would uphold; as recorded by a court 'record of assurance' contained in Meridian's declarations (MEL, 2003 [40;4]).

A year later in September 2004 the High Court heard the declarations sought by Aoraki Water Trust. The court refused to grant the first declaration stating that, "where a resource is already fully allocated in a physical sense to a permit holder, a consent authority cannot lawfully grant another permit unless specifically empowered by the RMA' (Aoraki v Meridian, 2004 [46]). It similarly refused the second declaration based on their findings for the first but also on the question of whether the purpose and principles of the RMA allow the enactment of a regional plan to override the allocation of an existing water permit. The court found against the proposition (Aoraki v Meridian, 2004 [66]). While the decision of the court is not binding, because Aoraki's declarations were dismissed, the rationale behind the refusal to grant Aoraki's declarations becomes important in law and clarifies Meridian's consent position making clear the status of water allocation and permits in the upper catchment (Milne, 2005).

Prior to both those hearings, in May of 2003 Meridian announced the proposal for Project Aqua. The proposal incorporated a sixty kilometre long canal diverting $70 \%$ of the water from the lower Waitaki, passing it through six generating units before returning it to the natural river course (Concept Consulting Group, 2004). At the time there was no regional plan for the allocation of water in the Waitaki catchment nor was there a set minimum flow. Additionally the lower Waitaki was well developed in terms of irrigation by this time and there was general recognition that the diversion of $70 \%$ of the river, coupled with emerging irrigation schemes (such as Aoraki's) would over allocate the catchment resource (Hansard, 2004a).

The response followed on 11 September 2003, in the form of a Ministerial call-in of all pending resource consents under s 140 of the RMA. This was followed by the passing of the controversial, 2004 Resource Management (Waitaki Catchment) Amendment Act (the Waitaki Act). The stated purpose of this legislation is to require the allocation of water in the Waitaki Catchment on a basis consistent with the purpose and principles of the [RMA] (Waitaki Act, 2004). 
However, while remaining consistent with the purpose and principles of the RMA, the Waitaki Act is also wider in scope. It differs from the RMA in allowing the consideration of competing resource consents in an equitable manner within a statutory framework. Case law has determined that under the RMA consideration of applications can not be based on the merit of one over the other but must be considered sequentially from the time of notification producing a 'first-in, first-served' system for water allocation (Chapman Tripp, 2003). The legislation aimed to circumvent this by the establishment of the Waitaki Catchment Water Allocation Board. The Board was appointed by the Minister for the Environment and tasked with producing the Waitaki Catchment Water Allocation Plan (the Waitaki Plan) - a catchment wide allocation plan from which the competing merits of water applications could be assessed. To ensure this occurred, the Waitaki Act deferred the notification of all pending resource consents until the Plan was operative, and a priority of consideration could be determined under the framework by an appointed panel (Waitaki Act, 2004). The hearing panel consists of three Commissioners appointed by the CRC and chaired by Peter Skelton (a former Environment Court Judge).

The Waitaki Plan became operative in July 2006. The notification of all pending consents for the upper Waitaki occurred uniformly in June 2007, comprising 116 consent applications from 44 separate proposals (Skelton, 2008). The Hearing Panel subsequently announced a Priority Decision in April 2008 and consent hearings, at the time of writing, are currently in process. These variously include the right to take and use water for agriculture and horticulture activities. However, it should be noted that the Waitaki Plan deals only with water allocation, consents pertaining to discharge or disturbance to lake/river beds are governed by the not yet operative, Proposed Natural Resources Regional Plan (PNRRP) notified on July 2004.

In summary, with the 1999 split of ECNZ into SOEs, Meridian became owner of the Waitaki infrastructure and faced an immediate renewal of water rights. Meridian elected not to pursue renewal under the original 1969 order in Council, but through the Canterbury Regional Council. With the introduction of the RMA in 1991, those water rights became water permits and expire in 2025.

In 2003, several large consent applications for the Waitaki River highlighted the inadequacies posed by the lack of a catchment wide allocation plan, particularly when coupled with an over arching policy document that operates on a 'first-come, first-served' basis - the RMA. The 
Environment Minister responded by proposing specific legislation be enacted for the Waitaki Catchment and followed this with a Ministerial call-in of all pending resource consents.

The Resource Management (Waitaki Catchment) Amendment Act 2004 was subsequently promulgated and the Board produced a statutory allocation plan that became operative in July 2006. All suspended consent applications have now been notified, an order of priority announced and hearings by a Panel appointed by CRC are currently considering applications.

This section has introduced the legislation surrounding water allocation in this region to date. This provides important back-ground information for the following chapter and also illustrates the dearth of clear water management that has been inherent in New Zealand. It highlights the need for forward thinking and robust policy with regard to water so that sustainable outcomes can be ensured. For a succinct timeline of the legislation and hydroelectric development see Appendix D. 


\section{Chapter 4 - Analysis and Critique of the Waitaki Act and Waitaki Plan}

This chapter, rather than display one recognised analytical method of policy analysis, argued within the text to be most applicable to this particular policy issue, instead adheres to the 'basic analysis' ideal described by Patton and Sawicki (2002). This differentiates between 'researched analysis'- described as being codified, with routine steps and a toolbox of set methods; and 'basic analysis', which focuses on logic and common sense, and where "the most compelling feature is whether the consumer understands it, is able to follow its logic and as a result is able to formulate better policy"(Patton et al., 2002:2).

\subsection{Introduction}

The previous chapter provided a historical outline of the legislation surrounding this region to date. The purpose of this was to highlight the various competing claims to water and to illustrate the ambiguity that surrounded the legal status of rights to water, for much of that time, for all of the stakeholders involved. That ambiguity regarding water rights, was finally resolved via the High Court and Environment Court application for declarations by Aoraki Water Trust and Meridian respectively. Subsequent legislation pertaining to the area, the 2004 Resource Management (Waitaki Catchment) Amendment Act (the Waitaki Act), was promulgated to provide further clarification on water use by the development of the 2006 Waitaki Catchment Water Allocation Plan (the Waitaki Plan) by the Waitaki Catchment Water Allocation Board (the Board). The way this was to be achieved was two-fold. Firstly, the Waitaki Act allowed for a comparative consideration of applications for water takes, and determined a 'priority of hearing and decision'. Secondly, to facilitate the hearing and decision process the Waitaki Plan was to set rules regarding minimum flows and allocation to specific activities.

This chapter will argue that in setting annual allocations to specific activities, the Waitaki Plan has, in fact, not provided clarity on water allocation in the region but has once more injected a note of ambiguity regarding the competing demands of hydroelectricity generation 
versus irrigation in the upper Waitaki Basin. In addition, the Waitaki Act in its wording and specific exclusion of certain provisions shifts the focus firmly away from the national perspective resulting in a regional plan that could have nothing but, a strong local and regional-centric perspective. The following sections will discuss these ideas further.

\subsection{The Waitaki Act}

As previously mentioned, the Waitaki Act is legislation unique to a specific catchment in New Zealand - no similar legislation exists for any other catchment in the country, and the passing of the Bill elicited much criticism of the government and questioning of the motivation behind it. There were calls for a general review of the RMA to allow this same approach for all catchments (Chapman Tripp, 2003; MfE, 2004b); and there was much discussion from the opposition on whether the Bill was a way of fast tracking state owned Meridian's Project Aqua (Hansard, 2004a\&b).

\subsubsection{Exclusion of the RMA Energy and Climate Change Amendment 2004}

At the same time this Bill was being drafted, another amendment Bill to the RMA was making its way through the parliamentary system. This was the Resource Management (Energy and Climate Change) Amendment Act (the Energy Act) and it was passed 1 March 2004 - the Waitaki Act followed on 16 September 2004. The stated purpose of the Energy Act is to amend the RMA to make explicit provision for all persons exercising functions and powers under the RMA to have particular regard to the benefits to be derived from the use and development of renewable energy (Energy Act, 2004). However, a crucial point of the Waitaki Act is in s 18 (2) (b) under Matters relevant to the regional plan where it specifically states that the Energy and Climate Change Amendment will not apply to the development of the forthcoming regional plan (Figure 4.1). 


Matters relevant to the regional plan
Application of principal Act to development, contents, and approval of regional plan
The principal Act, including the provisions of Part 2, applies, with the necessary modifications, to the
development, con- tents, and approval of the regional plan under this Part as if it were a regional plan
developed by a regional council, except as expressly provided otherwise by this Act.
Except as provided in subsection (3), the following provisions do not apply to the development of the
regional plan under this Part:
(a) section 37(1)(a) and Part 5 of the principal Act:
(b) Resource Management (Energy and Climate Change) Amendment Act 2004.
Sections 63(1), 66(2A), 67(1) and (2)(a), 68(1), (2), (3), (5), and (7), 69, 70, and 77A to 77D apply, with
(3) necessary modifications, as if the Board were a regional council.

Figure 4.1 Section 18 of the Resource Management (Waitaki Catchment) Amendment Act 2004.

This exclusion seems incongruous considering that the Plan is a statutory document governing the allocation of water in a catchment, which is coincidentally the largest hydro-electricity generating catchment in New Zealand.

The question must then be asked, why was the Energy Act specifically excluded from the Waitaki Act? The first place to seek such an answer is the Annex1 report - this is the report outlining the decisions and principal reasons for adopting the Plan. The Annex 1 report, (along with a section 32 report required under the RMA) was a statutory requirement of the Board under s 26 (3)(a) of the Waitaki Act. However, a review of both the reports reveals little detail about the Energy Act exclusion. The Annex1 report merely states, "the amendments to the RMA made by the Resource Management (Energy and Climate Change) Amendment Act 2004, which require functionaries to have particular regard to the effects of climate change, and to the benefits of the use and development of renewable energy, do not apply to the development of the Plan" (Annex1, 2005 [6]). While the Section 32 report, which admittedly is an evaluation of the provisions of the Plan, mentions it not at all (WCWAB, 2005).

A review of the MfE report from March 2004 on issues arising from the approximately 100 submissions received on the Waitaki Bill shows that not one takes issue with the Energy Act exclusion - not even Meridian. This is because it was not part of the original draft Bill at the time submissions were called for. It was introduced under (unanimous) recommendation from the Select Committee on 22nd March 2004 (LGESC, 2004: 10). Enquiries into to the reasoning behind the introduction of this clause, from several sources involved in the drafting of the Bill - including a member of the Select Committee, reveal a generally poor recollection of this being an issue (no source wished to be quoted). However, several surmised that it was 
introduced so as to not unduly influence earlier called-in applications that had previously been notified under different legislation.

Perhaps the government, after receiving such a high level of criticism for its attempts to balance competing demands on the resource, and after sustaining much 'finger pointing' regarding perceived SOE favouritism (Stevens, 2003), was then keen to distance itself from what that attempt seemed to imply. Other parties variously wanted to see either instream values protected from further large generation schemes or ensure those schemes weren't favoured above other uses (Hansard, 2004a\&b). Whatever the motivation s 18 (2) (b) was inserted with little or no controversy.

In retrospect it appears that though there was an arguably rational reaction by the government to the demands initially placed on this catchment, those demands, during the drafting process of the legislation, changed. This includes the March 29 withdrawal of Project Aqua by Meridian one week after the Select Committee reading of the Bill and insertion of s 18 (2) (b) (Hansard, 2004a\&b), and the High Court ruling pertaining to Aoraki's plans to gain water rights to Lake Tekapo. This necessitated substantial changes to the original Bill and it underwent a second re-write (described by some as a "gutting") following Meridian's withdrawal of its application for Project Aqua (Hansard 2004b). Regardless of the reasoning behind the insertion of s18 (2) (b), the result is an Act that specifically excludes the consideration of renewable energy in a regional plan pertaining to the largest hydroelectricity generating catchment in New Zealand. This would further effect the development of the Plan and this is discussed in section 4.3.

\subsubsection{Removal of the National Perspective}

This shift from seeming to be biased toward the national interest is also evident in the wording of the Bill as it progresses through the drafting process. In a report to the Local Government and Environment Select Committee advising on the issues arising from the submissions, MfE officials' recommended to the Select Committee, under the section outlining how the Board will allocate water to the various categories of competing activities (original clause 20) that the term national perspective be deleted. They recommended it be replaced with "then have regard to the social and economic benefits and costs of each category of competing activity referred to in subsection (1) "occurring at a national, regional, and local level" (MfE, 2004b). The term national perspective had originally been defined in a 
sub clause as, including the sum of relevant regional and local social and economic benefits and costs, but many submitters seemed to feel this placed undue emphasis on the national benefit, and the officials' making recommendations and the Select Committee agreed (MfE 2004b:38; LGESC, 2004).

The officials' noted that "given the national interest in the Waitaki - it is important to make it absolutely clear that the national perspective should be considered [but] it is not intended that this should prevail over local or regional considerations if these have greater net benefits than any national assessment (which is a matter for the board to decide)" (MfE, 2004b:40). The ultimate rational for excluding the phrase national perspective was that the wording was new terminology to the RMA and there may be confusion about its meaning in the absence of case law pertaining to it.

Regardless, after the second re-write even the phrase 'national, regional, and local level' is absent from the final Bill and this in part contributes to the regional-centric focus of the final Plan. In fact a search of the Bill reveals the word 'local' occurs 24 times, the word 'regional' occurs 114 times and the word 'national' not at all. The national interest $i s$ represented by the Bill's adherence to the RMA as the principal Act in s 6, matters of national importance regarding the use, development and protection of natural and physical resources; but is not specifically mentioned in the final draft in regard to the national benefits of allocation to various uses.

This regional focus is further evidenced in two ways. Firstly by the Board's apparent disregard of several cost benefit analyses relating to the efficiency of various allocations between users and secondly by the subsequent allocation volumes attributed to agriculture in the upper part of the catchment. These two aspects will now be explored in greater detail. 


\subsection{The Waitaki Plan}

\subsubsection{Efficient Allocation and CBA}

In drafting the Waitaki Plan the Board was charged with producing an allocation framework on a basis consistent with the purpose and principles of the RMA. Therefore the Board would be beholden to take into its considerations section 7 (b) the efficient use and development of natural and physical resources. The Board was helped in this decision-making process by a variety of reports, as listed in the Annex1 Report appendix (Annex1, 2005). Included among these reports, are several commissioned by both MfE and the Ministry for Economic Development (MED) on cost benefit analysis (CBA) of the merits of irrigation development versus further electricity generation.

The reports use economic modelling to assess several scenarios, variously incorporating components of new hydroelectric development and irrigation, and all clearly indicate the value of retaining water in the upper reaches of the catchment for hydroelectric generation versus irrigation on both a $7.5 \%$ and a $10 \%$ discount rate (Brown et al., 2005; Harris et al., 2004; SKM, 2004a). For example, in the 'National Cost Benefit Analysis to take Water from the Waitaki', the report states, "The impact of irrigation uptake on lost generation is significant for takes above Tekapo. While the proposed diversions from Lake Tekapo are able to benefit from relatively low off-farm capital costs, their overall economic viability is also reduced by the large amount of lost generation capacity. At the national level, the loss in generation capacity from this demand is estimated to be of the order of $0.4-0.6 \%$." (SKM, 2004a:5).

Further, in a report on 'Environmental, Economic and Social Impacts of Irrigation' the summary finds, "The results show that the options for irrigation tested produce considerable surplus in terms of net benefit from agricultural production, but a considerable loss in terms of hydro-generation. Using base case assumptions the hydro losses are greater than the agricultural benefits in both scenarios of development. There is little difference in terms of agricultural outcomes between the two scenarios, but the electricity generation losses are 10 to 20 percent greater when the quantity of water specified in the former Order in Council is concentrated in the upper part of the catchment. The negative outcome overall is not changed by the discount rate used, but is very sensitive to the assumptions about agricultural returns and inputs including water use” (Brown et al., 2005 [10]; my emphasis) 
Additionally, the report from Harris Consulting et al, which is a regional economic analysis concedes, "that at a $7.5 \%$ discount rate irrigation scenarios mostly produce a positive NVP [net present value]..... [and] show substantial gains to primary production in the region, but this is offset by large costs in terms of lost energy production. However at $10 \%$ the values are almost all negative, with some primary production values negative even before the energy losses are included" (Harris, et al., 2004: xii)

In spite of this the Board went on to allocate 275 million cumecs $\left(\mathrm{M} \mathrm{m}^{3}\right)$ of water to irrigation per year to the upper catchment. The following will examine how that figure was determined and how it differs from current usage.

\subsubsection{Adequacy and Accuracy of Data the Plan is Based Upon}

Part of that allocation to irrigation is an acknowledgement of the agreement between Meridian and a coalition of landholders - the Mackenzie Irrigation Company (MIC) - regarding a volume of water to be available for irrigation, similar to that specified in the 1969 Order in Council, as negotiated during the 1990 renewal of water rights with the Canterbury Regional Council (see Chapter 3). This agreement includes an allowance of $150 \mathrm{M} \mathrm{m}^{3 /} / \mathrm{yr}$ to be available (subject to consent approval from CRC) to members of the irrigation company. The Board in its Annex 1 report stated that it was not going to explicitly incorporate the agreement into the plan (Annex1, 2005 [46-52]) but that they had given it regard by allocating to irrigation, an amount that would allow effect to be given to the substance of the agreement (Annex1, 2005 [206]). This is the very same agreement that Meridian acknowledged and backed via a court record of assurance to honour those terms in 2003 (see Chapter 3) (MEL, 2003 [40] 4). This is in addition to water already allocated to existing consent holders of the upper Waitaki.

Therefore, the remaining $125 \mathrm{M} \mathrm{m}^{3} / \mathrm{yr}$ comprises the amount calculated by the Board (based on the evidence before it) of the existing 'effective' annual allocation for the upper Waitaki. The Board states in the Annex1 report, as per its statutory requirement, that "the information available to it was sufficient to provide a sound basis for the allocation decisions and to identify appropriate relevant matters to be addressed when considering implications and the provisions of the Plan" (Annex1, 2005 [40]).

However, this assertion is not supported by earlier or subsequent studies. Many of the consents currently issued by ECan have no provision for metering and/or reporting as conditions within them (Lincoln Environmental, 2002). For example, a review of the ECan 
database reveals that, of the 54 consents pertaining to 'up-stream of the Waitaki Dam' (for agriculture and horticulture) just eight require metering with an annual report submitted to ECan. Consequently actual usage volumes are difficult to gauge. An economic evaluation report (listed by the Board) states that information regarding the current utilisation of consents is virtually non-existent and cites the lack of accurate data on actual water use as hindering the ability to rank various allocation alternatives (SKM, 2004a).

In spite of this the Board considered it had sufficient information with which to determine water allocation and, as mentioned above, derived a volumetric figure of 125 million cubic metres for the existing effective annual allocation. However, a subsequent report regarding current annual allocation, to the Commissioner responsible for determining the order of priority for consent hearings, reveals this figure to be inaccurate. In fact legal advice to Environment Canterbury has been to disregard the Board's figures on annual water allocation volumes (because it is based on flawed methodology) and produce their own assessment of currently allocated volumes (Sullivan et al., 2007).

The legally recommended method to determine current annual allocation is to use, if included in the consent details, the 'implied' annual allocation limits, or where these are missing use the estimate approach detailed in Schedule WQN9 of the Proposed Natural Resources Regional Plan (Sullivan et al., 2007; ECan, 2004). The WQN9 was itself the focus of a 2005 review, based as it was on figures from the 1988/1989 season - a La Niña drought year (ECan, 2005; Tait et al., 2005). The currently accepted WQN9 approach uses parameters such as peak irrigation demand - calculated on the maximum consented rate with rainfall and evapotranspiration factored in and when applied by Sullivan et al., this method yields vastly dissimilar results to those derived by the Board - as illustrated in Figure 4.2.

\begin{tabular}{|l|l|l|l|}
\hline Upper Waitaki \\
\hline Area (ha) & 9,680 & 9,680 & 9,680 \\
\hline PAW & Light & Medium & Heavy \\
\hline Land Use & Intensive Pasture & Intensive Pasture & Intensive Pasture \\
\hline Effective Rainfall (mm) & 200 & 200 & 200 \\
\hline Annual Volume $\left(\mathrm{m}^{3}\right.$ ) & \multicolumn{1}{|c|}{$\mathbf{5 9 , 5 3 2 , 0 0 0}$} & $\mathbf{5 3 , 2 4 0 , 0 0 0}$ & $\mathbf{4 5 , 4 9 6 , 0 0 0}$ \\
\hline GPF Annual Volume 123.8 million $^{\mathbf{3}}$ & & \\
\hline
\end{tabular}

Figure 4.2: Effective allocation for the upper Waitaki using WQN9 methodology. The effective rainfall has been assumed at $200 \mathrm{~mm}$, although it is noted there is variation within this parameter and it is assumed all farming is intensive pasture, which it is not. PAW stands for plant available water and is a reflection of the soil properties. The GPF annual volume is that calculated by a previous study and is similar to the Board's figure. The table seeks to highlight how much of a reduction in effective allocation the adoption of WQN9 to all consents may have based on this worst-case scenario (Sullivan et al., 2007) 
In the upper catchment, specifically upstream of the lake outlets, the disparity between what is the current 'effective' annual volume of existing consents and what has been allocated in the Plan is even greater. The Board did not provide current water take estimates for all the specific sub-catchment areas they allocated to (for example those above the lake outlets of Pukaki, Ohau and Tekapo). Instead they note in the Annex 1 report a cumulative figure of $2.4 \mathrm{M} \mathrm{m}^{3}$ as the volume drawn from above the collective lake outlets and state, "a provision for this will be in the Plan plus an allowance for likely expansion" (Annex1, 2005 [204]).

The final allocation provision for upstream of the lake outlets in the Plan is $28 \mathrm{M} \mathrm{m}^{3}$. This includes volumes of $8 \mathrm{M} \mathrm{m}^{3}$ upstream of the Lake Tekapo outlet, $8 \mathrm{M} \mathrm{m}^{3}$ upstream of the Lake Pukaki outlet and $12 \mathrm{M} \mathrm{m}^{3}$ upstream of the Ohau outlet, which equates to more than a ten-fold increase in the volume of water currently utilised (as calculated by the Board). This substantial increase in allocation is further highlighted if the estimates of 'effective' annual volumes calculated from Sullivan et al are compared. Those figures reveal existing resource consents provide $0.867 \mathrm{M} \mathrm{m}^{3}$ for upstream of Lake Tekapo and $0.347 \mathrm{M} \mathrm{m}^{3}$ for upstream of Lake Pukaki with none upstream of Lake Ohau; a total of just $1.214 \mathrm{M} \mathrm{m}^{3}$. This substantial increase in allocation has significant impacts on the property rights of existing consent holders, the implications of which will be discussed further in section 4.3.3.

The Board perhaps pre-empted a challenge to their methodology by an additional Annex 1 reasoning as follows, "Rules and other methods of implementation of policies for achieving the objectives of the Plan call for evaluative judgements on conflicting considerations, and their relative significance or proportion of the final outcome. They are not generally the result of computation or application of scientific principle or method, but are judgements on which reasonable and informed people (including members of the Board) might reasonably differ"'(Annex 1, 2005 [27]). Nevertheless some degree of accuracy should be attempted particularly given the disparity in assessment between the Board and the work conducted by Sullivan et al using the legally recommended WQN9 methodology and the implications this has for the Plan achieving its objectives of providing clear allocation guidance. 


\subsubsection{How Robust are the Objectives of the Plan?}

The Board states it is required to allocate water for activities under s 13 of the Waitaki Act, where,

In carrying out its function under section 6, the Board must include objectives, policies and methods (including rules if appropriate) in the regional plan, to provide for...

(c) The allocation of water to activities, as appropriate (Waitaki Act, 2006: my emphasis).

The Board went on to draft five objectives, of these, Objective 3 states, in allocating water, [the Board is to] recognise beneficial and adverse effects on the environment and both the national and local costs and benefits (environmental, social, cultural and economic) (WCWARP, 2006). The Board goes on to assert in the Annex1 report "that allocating an amount of water for each of a diverse range of activities provides for social and economic wellbeing across the catchment community, the local community and the nation" (Annex1, 2005 [195]). Except that, for the water allocated in the upper catchment, economic and social wellbeing (or environmental, notably absent from the above definition) does not apply for several reasons.

Firstly the allocation does not provide economic wellbeing in the upper catchment based on the reasons previously discussed in section 4.3.1. Secondly, the allocation to agriculture does not provide for social wellbeing due to an introduced element of ambiguity for takes above the lake outlets - the very issue the Plan was supposed to resolve. For example, as determined by the 2003 Environment Court declaration, the existing consents granted to Meridian for the purposes of electricity generation effectively grant them more water than enters the lake and therefore all that water is fully allocated to them (MEL, 2003). This in turn implies Meridian has an excellent case to counter any future application for a water permit that might arise in this area, regardless of the allocation allowance in the Plan.

However, the Board countered the non-derogation principle and justified their allocation on the basis of the findings in Aoraki Water Trust v Meridian. The court transcript included obiter dicta discussing statutory provisions, which could arguably empower a regional council to review the conditions of existing consents and enable the rule regarding allocation to be met (Aoraki v Meridian, 2004 [52]; Annex1, 2005 [56-60]). The provisions include section 68(7) of the RMA, which enables a regional plan to include a rule that affects existing 
consents; and section 128 to 132 , which detail the circumstances when consent conditions can be reviewed.

However, the court did not acknowledge these as authorisation for ECan to grant another party a water right if that permit would reduce the amount available to satisfy Meridian's consents (Aoraki v Meridian, 2004 [55]). Indeed, the Board, in responding to submissions, declined to include specific direction to the regional council on this matter stating that under the RMA it is up to the discretion of the local authority to determine if review is required (Annex1, 2005[63]). This raises the question of why the Board allocated these volumes at all. It appears the Board is partly relying on the expiry date of existing consents (2025 for Meridian) before the allocation contained in rule 5 for the upper catchment can be given effect (Annex1, 2005 [59]).

This arguably has not provided certainty and clarity for potential abstractive users of water in the upper catchment and tragically the area is once more governed by legislation that provides water on paper but in reality is unable to supply it. Under section 13 the Board has neglected to apply the caveat " as appropriate" and has allocated volumes well exceeding current usage to an activity in an area that is clearly contravening the objectives of the Plan. They have 'left the door open' to other users of water and in so doing have introduced uncertainty regarding the property rights of existing users and provided no clear direction for a resource increasingly under pressure.

\subsubsection{Additional Considerations}

From a national perspective, as discussed above, three separate cost benefit analyses (CBA) on the economic value of irrigation versus hydroelectric generation in the upper catchment clearly state, that allocation up-stream of the Waitaki Dam will affect the generating potential of the existing infrastructure and so detract from any gains through alternative uses. CBA attempts to forecast the future and is arguably subjective and yet the logic behind these assertions is not difficult, from a common sense point of view to understand. Mentioned in one study, but not included in the actual analyses, is the issue of externalities associated with allocation to alternative uses. While these may be difficult to quantify they are no less real and should also be given consideration. 
This includes the issue that any allocation to irrigation should incorporate externalities associated with development of the alternative generation capacity required to compensate for the reduction in generation potential. This includes the costs to investment of a reduced security of supply and the required additional capital investment in infrastructure. Closely linked with this are the externalities involving greenhouse gas emissions (GHG). That includes, emissions generated by both the burgeoning dairy industry (made possible by the water re-allocated from renewable, emission-free hydroelectricity) and the potential emissions from the alternative generation options of coal and/or gas, required to compensate for the electricity shortfall. Not only should the analysis include the costs of these to the environment, an exercise in pricing the priceless (Heinzerling, 2002); but also the economic costs as it detracts from New Zealand's Kyoto targets. This last is just one of the costs borne by all taxpayers while the immediate benefits accrue to a few. From a national perspective, removing a resource from a renewable energy generating potential and allocating it to an industry, which currently contributes to $48 \%$ to our GHG emissions profile is incompatible with a host of other government policies and initiatives including the Kyoto commitments and the, then current, 2001 Energy Efficiency and Conservation Program of Action.

This chapter has reviewed the 2004 Waitaki Act and the 2006 Waitaki Plan from a 'basic analysis' perspective. In so doing it has highlighted the weaknesses and inconsistencies both within the legislation itself and with its adherence to wider government policy. Further aspects will be addressed in the discussion, Chapter 8 - following the chapters on fieldwork. 


\section{Chapter 5-Fieldwork}

This chapter explores the rationale for conducting the research. It then examines the technique used, including the supporting theory behind it, how the sites were selected and equipment installed. The following chapter will present the fieldwork data and a full discussion of the results will follow in Chapter 7.

\subsection{Fieldwork Rationale}

For agriculture to be sustainable two main aspects need to be considered. Firstly, the (and how they function) of the natural resources that support the industry must be known. This includes the soils (their properties, health and response to water) upon which the industry is based; it also includes the hydrological system (both ground and surface waters) along with climate (including precipitation and evapotranspiration rates) that provide the necessary moisture. Second, a cost-benefit analysis must be made on the most efficient use of inputs (in this case water) to the industry system.

The question of whether irrigation is the most economic use of water in the upper Waitaki has been addressed in previous studies and discussed in Chapter 4. However, a literature review reveals that an assessment of the natural resources and their response to farming intensification has not been adequately addressed. Given the genesis of the soils and the climatic regime of the basin (Chapter 2), it seems reasonable to question the sustainability of dairying in this area. The fieldwork undertaken aimed to address one aspect of this by highlighting the soil response to, and potential effects of, intensive irrigation. There is a general paucity of research surrounding the soil's response to moisture in this region. The following summarises the extent of previous work that has been done.

Hydrological research in this region extends back to 1966 when the Interdepartmental Committee was tasked with investigating the co-evolution suitability of irrigation schemes with hydro-electricity development (Chapter 3). One of the key tasks was to investigate the soil infiltration rates of the irrigable area (Opus, 2004). Several studies dating from this time 
are listed in the Winchmore Irrigation Research Station bibliography (Rickard, 1974). They cover aspects of irrigation of the lower Waitaki area (Cossons et al., 1970 1\&2; Taylor, 1971) but none consider the upper basin.

Further work, produced by the New Zealand Soil Bureau (Raeside, 1971), looks at land suitability for irrigation and is one of the few studies that considers factors such as climate, physiography and soil capability. The latter is based on a soil's physical properties and how they relate to the field capacity (the maximum amount of moisture that can be held against gravity) as well as its permeability and drainage. The soils of the Upper Waitaki were described as, "soils doubtfully suited for irrigation without further investigations, with moderate to severe limitations for irrigation" and predominantly mapped as Class 3 - "soils in well drained situations, with stony, very stony, or gravely texture, very high porosity, very high rates of infiltration and very low water holding capabilities" (Figure 5.1) (Raeside, 1971:9).

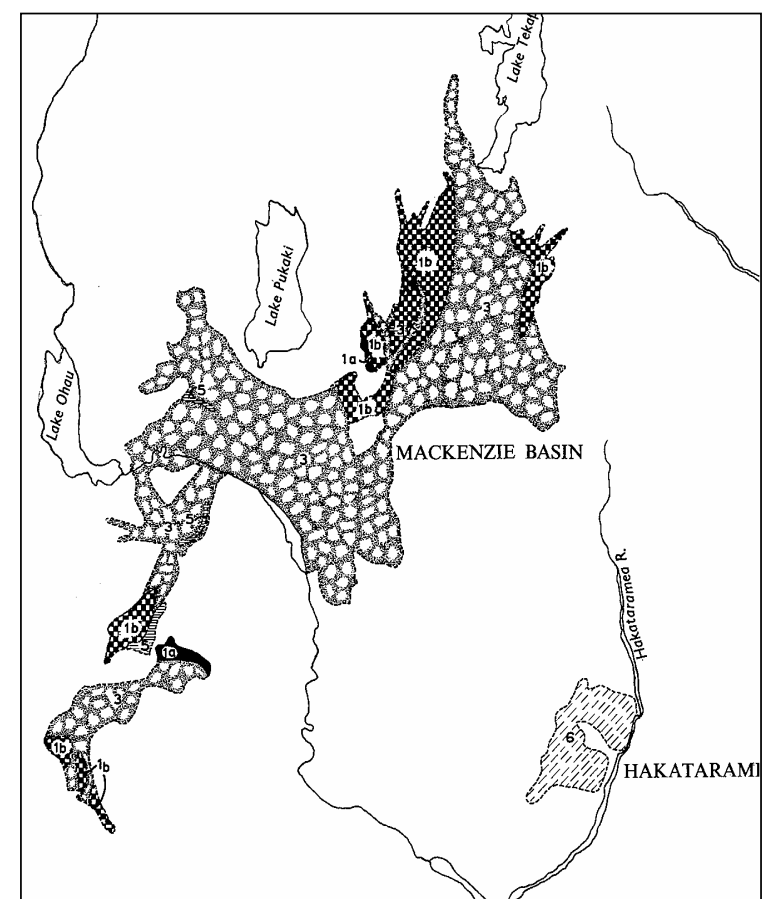

Figure 5.1: Irrigation classes for Mackenzie Basin soils (from Raeside, 1971).

Additionally, the irrigation systems considered by these early studies were predominantly border dyke and the farm systems were exclusively sheep/cattle. These systems require significantly less water than an intensive modern dairy farm. For example, as a guide to water requirements, the Waimakariri District Council (Canterbury) gives the following for daily 
agricultural requirements per head; sheep 4 litres, ewes 5.5 litres, and milking cows 64 litres (WDC, 2008; see also Lincoln Environmental, 2002).

The Soil Bureau report also focuses on the issue of good drainage versus water logging. However, while consideration is given to the implications of excessive drainage, this is related to the field capacity/wilting point, not to the sustainable use of water and/or potential nitrate/pathogen transport issue. This is perhaps understandable as this issue has only reached prominence following the relatively recent understanding of the long-term implications of nitrate transport from non-point source agricultural run-off (PCE, 2004). However, there would appear to be sufficient information now for this factor to be considered in current environmental assessments of sustainability. It should now influence the ability to obtain resource consent. While recent legislation supports this (WCWARP, 2005: Policy 16), consents for dairying continue to be approved without consideration of this cumulative environmental impact.

Other studies have considered the appropriateness of irrigation in this area with varying degrees of suitability attributed to different zones and soils (Kerr, 1973; Kerr, 1979; in Webb, 1992). However, again these are focused predominantly on border dyke systems rather than the intensive systems necessary for dairying.

Current information on irrigation suitability and soil structure for the upper basin can be found in the New Zealand Land Resources Inventory (NZLRI) database Soil Fundamental Data Layers (FDL). Each polygon includes information on:

- Land use capability (including limitations, if any, for arable use).

- Soil unit description (NZSC).

- Soil chemical attributes ( $\mathrm{pH}$, salinity, carbon, and P-retention).

- Topsoil gravel content (\%).

- Soil drainage parameters (including potential rooting depth, drainage class, and depth to a slowly permeable horizon).

- Soil moisture properties (including macroporosity, profile total available water, and profile readily available water).

In addition Landcare Research have compiled A Manual of Land Characteristics for Evaluation of Rural Land using these parameters (Webb, 1995). They have published several 
assessments for individual areas; however, no published land use assessment is available for the Waitaki basin at the time of writing.

In 2004, during the drafting of the Waitaki Catchment Water Allocation Plan the Waitaki Catchment Water Allocation Board called for relevant documentation to enable them to have the best information with which to formulate the Plan.

\footnotetext{
Adequacy of data, and further work required completed. identify:

- the resources in question,

- the requirements for water, and

- the consequential effects of the range of allocation options.
}

37 A number of submitters questioned whether there was sufficient information available to the Board to carry out its functions, and sought that the Plan be delayed until further research had been

38 In order to carry out the duties set out in the Act, the Board required sufficient information to

39 The Board had access to a significant body of technical information on the physical and natural resources of the Waitaki catchment, existing and proposed uses, and economic analyses of the various uses.

40 The Board found that the information available to it was sufficient to provide a sound basis for the allocation decisions, and to identify appropriate relevant matters to be addressed when considering applications under the provisions of the Plan.

Figure 5.2 Extract form the Annex1 Report produced by the Waitaki Catchment Water Allocation Board as an inclusion in the Plan of its reasons for adopting the provisions - per its statutory requirements.

However, in the appendix, List of reports received by the Board, there are no reports relating to irrigation suitability, or to soil moisture capability. In fact, one of the reports, an economic analysis of water use in the Waitaki states "The apparent variation in required climatic conditions of the relevant irrigation demands across the Waitaki Catchment is an area of concern.... specific annual crop water information is not available for the combination of soil types and irrigation application for all the zones considered"(SKM, 2004:159). In spite of this, the Board has included in the policies of the Plan, Policies on efficient and effective use. This includes Policy 16, which states:

By requiring resource consent applications for irrigation to meet a reasonable use test in relation to the instantaneous rate of abstraction and the annual volume of the proposal to take, use, dam or divert water including:

a. Consideration of land use and on-site physical factors such as soil water-holding capacity (my emphasis), climatic factors such as rainfall variability and potential evapotranspiration, and irrigation operation and management. 
b. Consideration of an irrigation application efficiency of at least 80 percent. Where the resource consent application is for an irrigation system with a higher application efficiency, the higher efficiency will be used.

c. Annual volumes based on either:

i) Soil moisture measurements, local rainfall and evapotranspiration modelling for the 1-in-5 year dry season (the year for which seasonal demand is exceeded in 20 percent of years); or

ii) The difference between peak total demand as shown in Table A1, Environment Canterbury Report UO5/15 and the effective summer rainfall exceeded 80 percent of the time from an approved rainfall site.

In itself, this is an excellent policy, except it is currently empty of substance, as little information exists for the upper Waitaki on which to make a 'reasonable use' test. A Lincoln Environmental report supports the need for data of this kind stating soil moisture is a critical measure in a soil water balance and is a vital, if underused aspect of determining both the timing and volume required for irrigation (Lincoln Environmental, 2000).

This thesis aims to observe the soil response to moisture (irrigation). It is anticipated this will highlight the potential effects of intensive irrigation in the upper Waitaki basin. The study is not intended to be definitive but to show that further study is required to enable a "reasonable use" test to be applied. This is critical when considering resource consents for dairying under the current legislation. ${ }^{6}$

\subsection{Justification of the field technique}

Due to its spatial and temporal variability soil moisture can be difficult to measure without disturbing the soil profile (Paige, 2008). The gravimetric method involving the weighing, drying and weighing again of a known soil volume is recognised as being the most accurate technique and is often used for calibration of other methods (Schlaeger, 2005; Zasueta et al., 1994; Robinson et al., 2003). However, this technique is impractical for the continuous

\footnotetext{
${ }^{6}$ In June 2008 under the Ministry of Agriculture and Forestry's Sustainable Farming Fund a project was launched to test the water holding capacity of soils by using electromagnetic induction). Electrical conductivity is closely related to soil texture and therefore water holding capacity. A web site update on 15 Oct 2008 stated data processing was occurring prior to producing maps. The field sites are adjacent to the Rakaia River and lower Waitaki in N. Otago. http://www.maf.govt.nz/sff/about-projects/search/CO7-012/index.htm
} 
monitoring required for efficient irrigation scheduling, or for the continuous and rapid data flow required for field studies (Walker et al., 2004).

Many automated methods have been developed for field studies including: tensiometers, used for measuring matric potential (capillary tension), and are an excellent tool for irrigation scheduling (Taylor, 1955; Hansen et al., 2000); nuclear techniques including neutron scattering, gamma attenuation, and nuclear magnetic resonance, however requiring the use of radioactive materials (Gardner et al., 1951, Reginato et al., 1964, Schlaeger, 2005), and, most popularly, electromagnetic techniques, which include time domain reflectometry (TDR) (Greco, 2007).

TDR is now widely used in studies measuring soil moisture (Evett, 2003; Zasueta et al., 1994; Seyfried et al., 2001). It provides a non-destructive in-situ method, enabling long-term continuous measurement to any depth, with remote downloading of data. Many techniques and systems using TDR technology have been developed; and validated, using the gravimetric method (Robinson et al., 2003; Walker et al., 2004).

TDR is based on the correlation between the apparent dielectric constant of a material and its volumetric water content (Topp et al., 1980; Paige et al., 2008). Dielectric constants vary between materials and have been quantified. For example: air 1; water 80 (at $20^{\circ} \mathrm{C}$ ); and a dry loam 3.5 (Curtis and Defandorf, 1929 in Noborio, 2001). The high dielectric constant (or relative permittivity) of water compared to that of soil makes it possible to determine the water content by analysing the waveform induced by a change in permittivity (and hence dielectric constant) with a change in water volume (Topp et al., 1998; Evett, 2003). The relative permittivity of soil to the volumetric water content can be modelled using an empirical equation, sometimes referred to as "the Topp equation" (Topp et al., 1990; Nadler et al., 2002). Simply put, volumetric water content is assumed to have a linear relationship with the travel time of a TDR signal. This can be modelled, producing a 'best fit' curve that enables a standard calibration for TDR probes which is accurate in most soil types (Evett, 2003; Nadler et al., 2002).

However, TDR systems can be expensive as they require a separate pulse and sampling unit and this also limits the ease of use (Seyfried et al., 2001; Kelleners et al., 2005). Another electromagnetic sensor, which operates on the same theory as TDR, is the transmission line oscillator. These have the required circuitry embedded in the probe head and can be directly 
connected to a datalogger (Campbell, 2007). The Campbell Scientific CS615 water content reflectometer is an example of a transmission line oscillator. This reflectometer was used in this fieldwork study (see section 5.3 for a detailed description of the reflectometer). A review of the literature revealed that the CS615 reflectometer has been used extensively in field studies since its commercial development in 1996. However, both laboratory testing (Seyfried et al., 2001), and field-testing (Chandler et al., 2004; Walker et al., 2005) identified a need for individual site calibration to obtain the most accurate readings possible - particularly in soils exhibiting high ionic conductivity and dielectric dispersion (Kelleners et al., 2005). That is, soils with high clay/organic matter and/or salinity values (Western et al., 2005; Bittelli et al., 2008).

Kelleners et al., stated the "effect [of electrical conductivity on apparent permittivity] is often ignored, but may be non-negligible in wet saline soils with high clay contents" (2001:1687). The soils in this field study were predominantly sandy loams with one silty loam, containing low-moderate clay contents (Table 1). In addition, they have uniformly very low salinity values according to the NZLRI soils FDL (Class $1=$ maximum salinity at 0-0.6 $\mathrm{m}$ depth of 0-0.04\%) and a corresponding conductivity rating of $<0.15 \mathrm{dS} \mathrm{m}^{-1} 1$ (Webb et al., 1995).

\begin{tabular}{|c|c|c|c|c|}
\hline Site & Soil type & Clay\%(at depth) & Clay\%(at depth) & Clay\%(at depth) \\
\hline Willowbank & Silt loam & $19 \%(0-22 \mathrm{~cm})$ & $\mathbf{2 0} \%(22-50 \mathrm{~cm})$ & n/a \\
\hline Holbrook & Sandy loam & $14 \%(0-9 \mathrm{~cm})$ & $\mathbf{8} \%(20-40 \mathrm{~cm}$ & $\mathbf{3} \%(58-70 \mathrm{~cm})$ \\
\hline Bendrose & Sandy loam & $12 \%(3-12 \mathrm{~cm})$ & $7 \%(25-35 \mathrm{~cm})$ & $\mathbf{1 6 \% ( 6 6 - 6 6 \mathrm { cm } )}$ \\
\hline Wairepo & Sandy loam & $12 \%(3-12 \mathrm{~cm})$ & $7 \%(25-35 \mathrm{~cm})$ & $\mathbf{1 6 \% ( 6 6 - 6 6 \mathrm { cm } )}$ \\
\hline
\end{tabular}

Table 1: Clay percentage at depth for each field site (from Webb, 1987)

In a paper on improving the interpretation of reflectometers Kelleners et al., (2001) found the 'fit' with the Topp theoretical model was 'good' for sand ( $0 \%$ clay, 0 conductivity), 'intermediate' for a sandy loam (5\% clay, electrical conductivity (EC) $2.5 \mathrm{dS} \mathrm{m}^{-1}$ ) and 'worst' for a loam (19\% clay, EC 7.7 dS m ¹). Seyfried et al., (2001) similarly concluded, that in conditions with low volumetric water, low EC and low temperature variation, standard calibrations were adequate. Given the very low salinity and EC ratings (Corwin, 2005) of the soils at the field sites; and given that the aim of the study is to look at the soil response to irrigation, i.e. relative changes rather than absolute values, it was determined the standard calibration would be adequate for the purposes and constraints imposed on this study. 


\subsection{Equipment}

The system used in the study consisted of up to six Campbell Scientific CS615 reflectometers connected directly to a Campbell Scientific CR10X datalogger housed on the surface and powered by a $12-\mathrm{v}$ battery. The reflectometer is a probe that can be inserted into the soil at any particular depth to determine the soil's apparent dielectric constant.

The CS615 reflectometers consist of two $30 \mathrm{~cm}$ parallel stainless steel rods $3.2 \mathrm{~mm}$ in diameter and $3.2 \mathrm{~cm}$ apart embedded in an epoxy head. The electromagnetic pulse is generated from circuitry within the probe head with the rods acting as wave-guides. The probe output is a square wave with a frequency that is proportional to the number of reflections per second and the arrival of the reflected wave triggers the next pulse (Seyfried et al., 2001). The CS615 reflectometer wave is affected by changes in propagation along the wave-guide determined by the dielectric constant of the media (O'Brien, 2001). The resulting changes in frequency are then recorded by a datalogger at predetermined timeframes. The CS615 accuracy is specified by the manufacturer as $\pm 2.5 \%$ (Walker et al., 2004).

The data was processed using Hilltop, hydrological software developed to store and analyse environmental data and used extensively in New Zealand by regional councils and others (Hilltop, 2008). Using Hilltop Manager it is possible to provide a graphical display of the changes in moisture content as a function of the changes in waveform. This graphical display therefore illustrates the change and variation in soil moisture volume at various depths over time. From this it is possible to interpret how the soil moisture changes, and how it responds to the volume and frequency of irrigation. In other words it is possible to investigate how soil moisture changes throughout the soil profile (particularly the root zone) in response to irrigation and therefore the efficiency of the irrigation regime.

\subsection{Field Site Selection}

The initial fieldwork proposition was to highlight the varying soil response to three irrigation methods (centre pivot, K-line and border dyke) on the same dominant soil type. GIS analysis identified the Mackenzie series as being one of the two most common soil series in the basin, Fork being the other. Mackenzie was chosen as it has a lower stone percentage and deeper soil 
profile (Webb, 1992). It therefore provides a greater sampling depth for the reflectometer probes.

However, obtaining permission from landholders proved problematic ${ }^{7}$. Given that the new irrigation installations are almost exclusively centre pivot, the fieldwork objectives were adjusted to observing soil moisture response under the same irrigation system (centre pivot) of differing soils.

Four monitoring sites were selected using the criteria of:

I. Being under centre pivot irrigation (either for dairying or sheep/cattle)

II. Having been granted permission by the landholder, and

III. Being of different soil types (under the NZSC series)

The majority of sites were inevitably concentrated in the most intensively farmed area. This is coincidentally the area of greatest dairying expansion and covers the area between Omarama and Twizel adjacent to State Highway 8 (Appendix A). Sites were analysed for their soil moisture response over two irrigation cycles (See Chapter 6). The fieldwork was carried out between 24/3/08 and 2/4/08.

\subsection{Installation \& Methodology}

Prior to installation, surface soil moisture content was sampled using a Campbell Scientific handheld $(10 \mathrm{~cm})$ moisture probe. This was to ensure the proposed site was representative of the surrounding area $^{8}$. From the proposed installation site, moisture readings were taken at 10 $\mathrm{m}$ intervals, in north, south, east and west directions, for a minimum distance of $30 \mathrm{~m}$. The readings were averaged and site location adjusted or confirmed, then recorded using GPS. The GPS locations were later plotted using ArcMap software on maps compiled from soil data obtained from Landcare Research (Appendix A \& B).

\footnotetext{
7 Problems encountered during requests for site access included late summer irrigation restrictions or reluctance to provide data on water use through fear of it being misused in pending consent applications (anon. pers. comm.)

8 Except at Holbrook where the irrigation system's position exerted time constraints on site installation.
} 
At each site, the turf mat was removed and a narrow trench was dug to below the root zone. Total depth was determined by where the gravel content would impede installation and operation of the reflectometers. The reflectometers must be completely surrounded by soil to function properly. A high gravel content in the soil matrix creates pore spaces allowing air next to the probe; this can change the apparent permittivity of the soil giving a false reading.

The CS615 reflectometer probes were inserted horizontally into the undisturbed soil of the trench headwall (Figure 5.3) and connected via coaxial cables to the data logger housed on the surface (Figure 5.4). A further probe was installed vertically to give an integrated measure of the volumetric water content within the upper $30 \mathrm{~cm}$ of the profile. Unlike the horizontal probes, the vertical probe was installed through undisturbed pasture and therefore may provide a more accurate reflection of soil moisture given that the influence of plant moisture uptake is included (Nadler et al., 2002:735). Guide holes for the horizontal probes were predrilled at a smaller diameter than the probe $(3.2 \mathrm{~mm})$ to minimise compaction and/or air spaces. These potential installation effects have been identified as the cause of inaccurate results in previous studies (Noborio 2001; Walker et al., 2002)

Each site had between four and six probes inserted at variable depths, plus one inserted vertically. Depths between probes were influenced by total depth to the stony layer and any changes in soil horizon or density (predominantly10 cm). The pit was then back filled and grass turf replaced. A tipping bucket rain gauge was installed and connected to the data logger to confirm the timing and volume of irrigation (Figure 5.4). The site was fenced off from stock and left for two irrigation passes to ensure 'representativeness' of the response to moisture. The time between passes varied between 6 hours to 54 hours $(6 \mathrm{hrs}$ at Wairepo, 25 hrs Willowbank, 39 hrs at Bendrose, 54 hrs at Holbrook). This time was dependant on the length and programmed speed of the irrigator. This in turn is related to the application volume and duration of irrigation. 


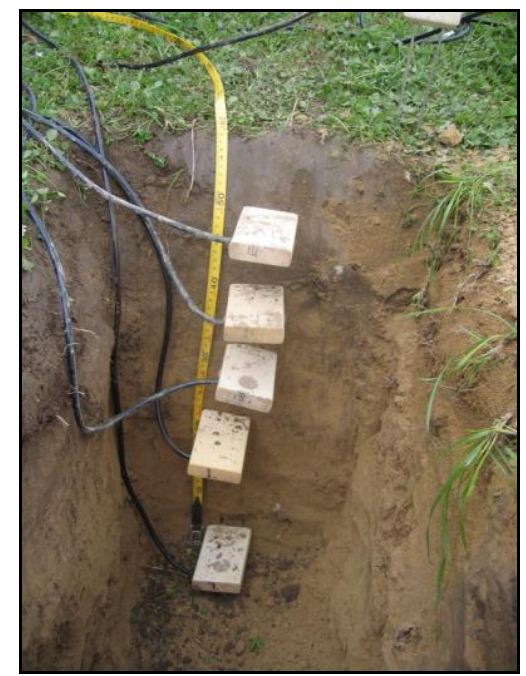

Figure 5.3: Probe installation.

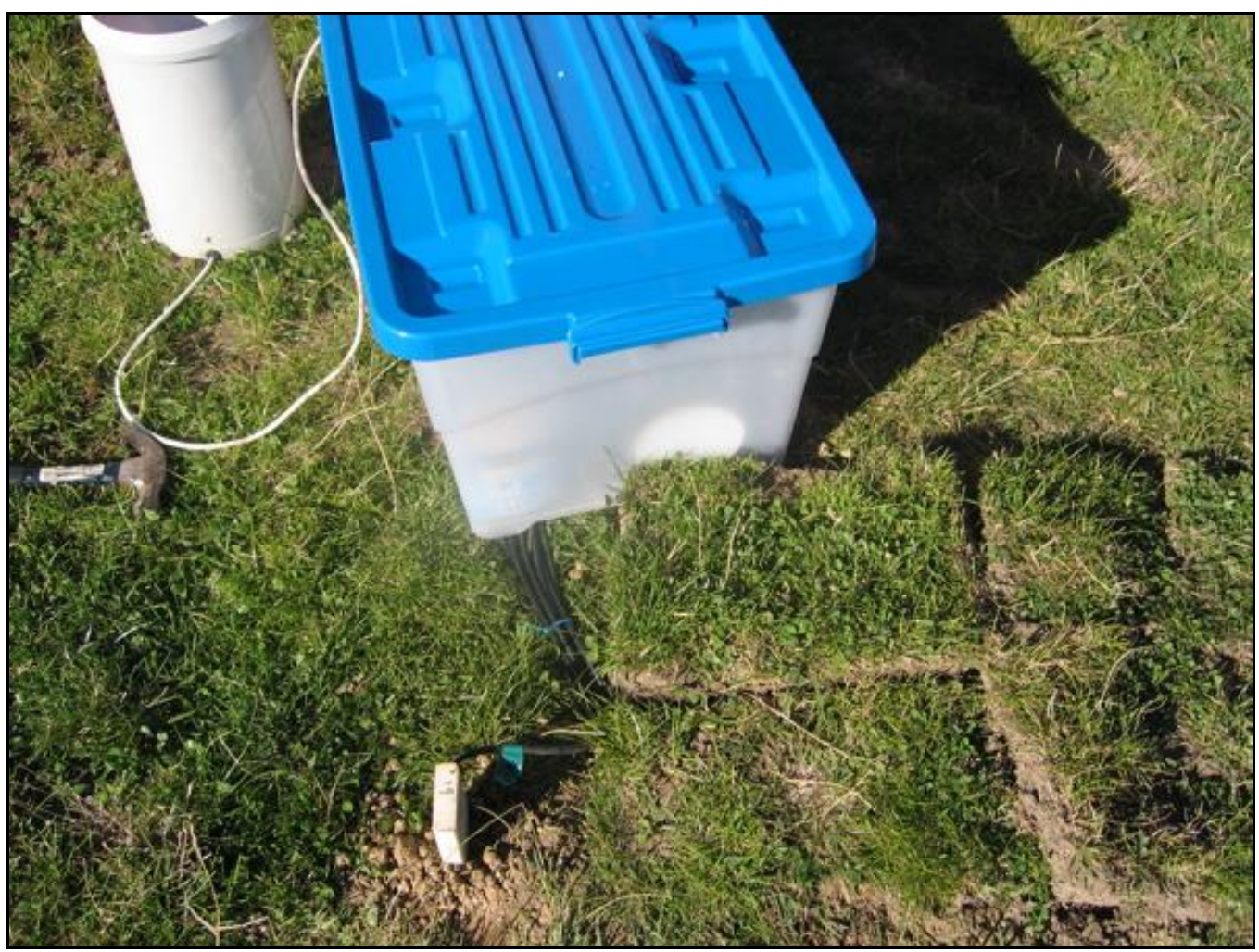

Figure 5.4: Site set-up: Rain gauge top left, datalogger (housed in plastic box) and vertical probe with coaxial cables left of the grass turfs.

This chapter has justified the fieldwork component of the thesis by raising the question that for an industry to be sustainable it must be the most efficient use of that resource. The fieldwork aims to explore that by examining how water moves under irrigation through the soil profile. If, as suspected from the soil source rock (moraine and alluvium), the soil acts as an effective conduit to the underlying shallow aquifers then an industry requiring high volumes of water and applying high rates of nutrients may not be considered sustainable in the long-term. 


\section{Chapter 6 - Field Data}

The previous chapter explored the justification for the fieldwork, and described the methodology adopted. This chapter details the raw data obtained during fieldwork. It includes a brief description of each site and soil profile; details of soil moisture at each depth; as well as a summary of the soil response to irrigation. A full comparative analysis and discussion of results will follow in Chapter 7.

In terms of the accuracy of the changes discussed, it should be noted that the manufacturer's accuracy specification for the CS615 is $\pm 2.5 \%$ (Campbell Scientific, 1997). However, where there are changes of $\geq 1 \%$, that are clearly attributable to an irrigation event, these are discussed also. This is due mainly to the low irrigation volumes, which at some sites resulted in incremental changes, although clearly as a response to irrigation rather than instrument noise (a discussion on the low irrigation volumes will follow in Chapter 7).

There are three main graphical representations used to display the data. The first is the profile average. This is a composite value for all depths where the soil moisture value for each probe has been extrapolated over that probes theoretical distal range then averaged. As a result, these values tend to be lower than that of individual depths, and particularly those in the top $30 \mathrm{~cm}$. It does however give the average value for the whole of the soil profile. These values have been converted to show volumetric water on the left-hand y-axis as a percentage rather than in $(\mathrm{ml} / \mathrm{ml})$ as with the other representations. The second representation is that of the vertical probe. These readings are obtained from the $30 \mathrm{~cm}$ vertical probe and give a good indication of the overall soil moisture of the top $30 \mathrm{~cm}$, particularly as they include the significant influence of plant uptake on soil moisture volumes, as they are installed through undisturbed pasture (Clothier et al., 1997). The third representation is a composite depth graph showing each individual depth, relative to the others, and displays soil moisture values in millimetres of water per millimetres of soil $(\mathrm{ml} / \mathrm{ml})$. The value of this representation lies in highlighting the differences of soil moisture within the profile and illustrating that soil moisture is not linear with depth. 
In all graphs irrigation appears on the right hand y-axis in millimetres. Within the text all discussion of soil moisture is in percentages for consistency and clarity. A location map of the sites, including the soil series can be found in appendix A.

\subsection{Willowbank}

Willowbank Station runs sheep, deer and cattle. It is a well-established farm in secondgeneration management. The farm system uses both k-line and centre pivot irrigation and (at the test site) has been trialling several pasture species for optimum production. The site location was on a gently south sloping terrace in between and adjacent to the two fault scarps that comprise Table Hill.

Site location E2269781 / N5640963; Elevation 473 m (a.s.1)

\subsubsection{Soil type - Humose Orthic Brown, Simons/Curraghmore (series)}

The observed soil profile corresponded with the description given for the Simons series rather than Curraghmore. Therefore, the following description focuses on Simons. These soils are described by Webb (1992), as being well drained, formed from moderately deep loess deposits on old terraces and fans. They are characterised by having:

- $15-25 \mathrm{~cm}$ silt loam to fine sandy loam topsoils with weakly to moderate developed granular and crumb structure.

- Olive to yellowish brown, silt loam to fine sandy loam upper B horizons with weakly to moderately developed nut or block and crumb structure.

- Average clay content of more than 18 percent in the upper $45 \mathrm{~cm}$.

- Thin clay skins in the lower B horizons.

- Depth to gravels variable from 45 to $150 \mathrm{~cm}$.

- Moderate permeability above gravels.

The observed soil profile comprised $20 \mathrm{~cm}$ of a dark friable (humose-rich) silt loam overlying $20 \mathrm{~cm}$ of semi-compacted clay (no visible leaching) in the B horizon. This showed an increasing percentage of river gravels $(\sim 4 \mathrm{~cm})$ with depth (max $60 \mathrm{~cm}$ ) (Figure 6.1). Campbell 
hand-held surface moisture probes (length $10 \mathrm{~cm}$ ) gave an average moisture content reading of $25.7 \%$ (see Chapter 5 for methodology).

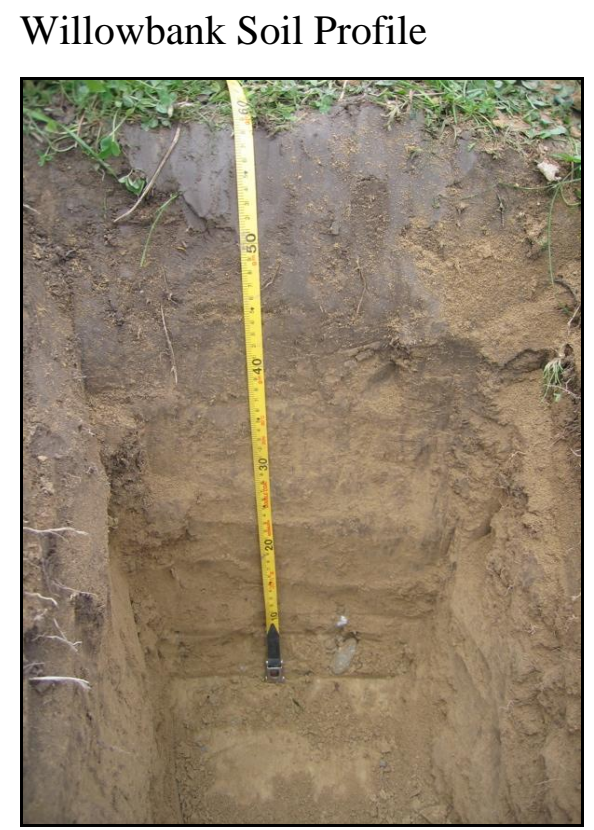

Figure 6.1: Willowbank soil profile showing dark humose rich topsoil and gravel appearing at depth 50cm

\subsubsection{Irrigation Overview}

- The probes were in place $24 \mathrm{hrs} 45 \mathrm{~min}$ before the first irrigation pass.

- First irrigation began 19:00 $28^{\text {th }}$ March

- ended 19:30 $28^{\text {th }}$ March

- The total applied water for the first application was $5.6 \mathrm{~mm}$ over $30 \mathrm{~min}$.

- There were $25 \mathrm{hrs} 50 \mathrm{~min}$ between irrigation cycles

- Second irrigation began 21:20 29 ${ }^{\text {th }}$ March

- ended 21:40 29 $9^{\text {th }}$ March

- The total applied water for the second application was $5 \mathrm{~mm}$ over $20 \mathrm{~min}$.

- Total water over two irrigation cycles within $95 \mathrm{hours} / 30 \mathrm{~min}$ was $10 \mathrm{~mm}$ (Figure 6.2) 


\subsubsection{Individual depth profiles}

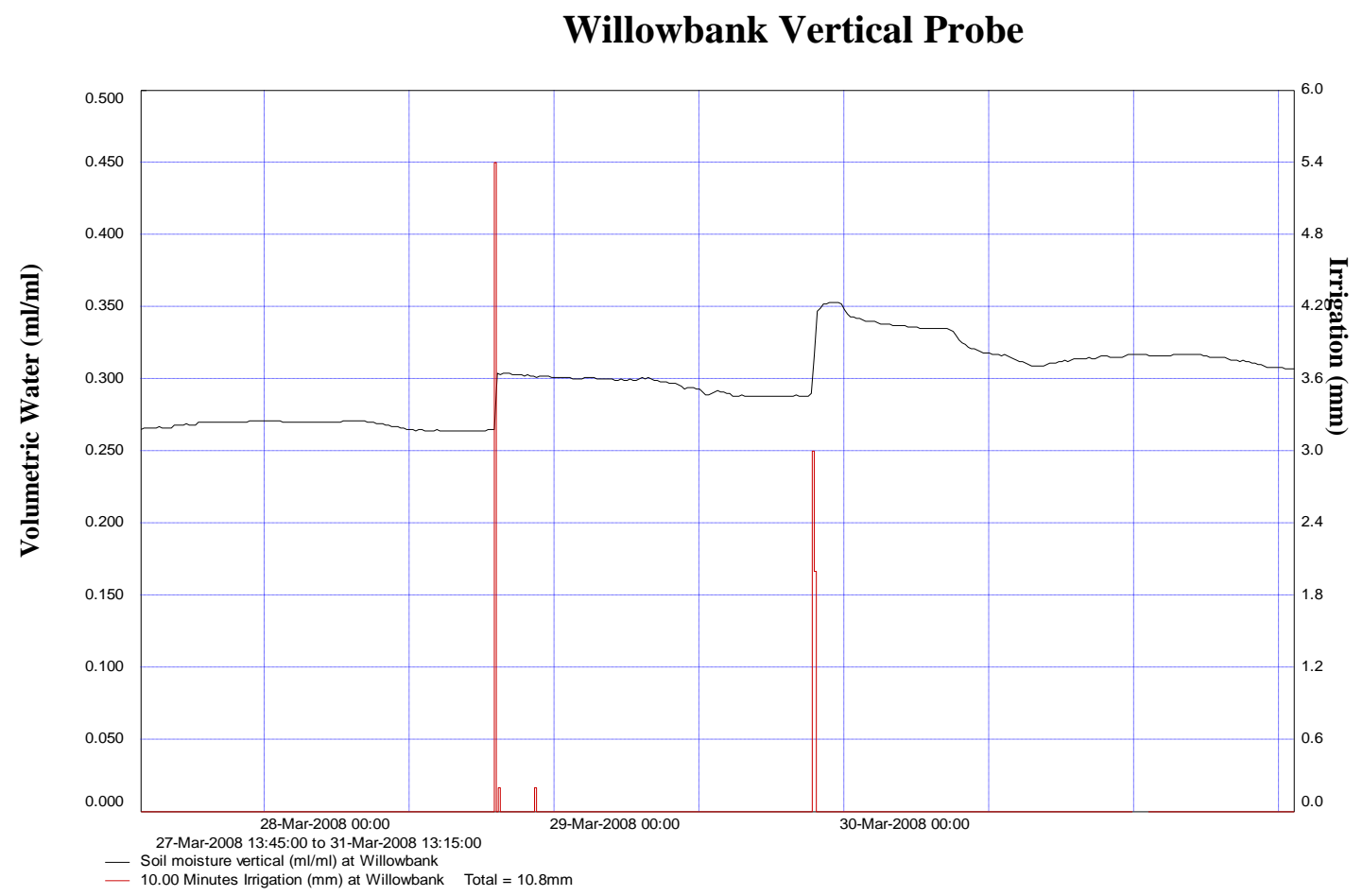

Figure 6.2. Willowbank vertical probe soil moisture in mils per mil of soil, converted and expressed in the text as a percentage. Probe depth $30 \mathrm{~cm}$.

\section{Willowbank Vertical Probe (depth $30 \mathrm{~cm})$}

- Initial soil moisture was $26 \%$.

- Immediately after the first irrigation soil moisture peaked at $30.4 \%$. Over the following $12 \mathrm{hrs}$ it stayed relatively constant. It then dropped $2.4 \%$ to $28 \%$ over the next $14 \mathrm{hrs}$ just prior to the second irrigation pass.

- From the onset of the second irrigation to $1 \mathrm{hr} 10 \mathrm{mins}$ afterwards, the soil moisture increased $5.5 \%$ to $33.5 \%$.

- Following this, for the next $16 \mathrm{hrs}$, the moisture content dropped to $30.9 \%$; a decrease of $2.6 \%$.

- The remaining $12 \mathrm{hrs}$ of the data set shows soil moisture remaining relatively steady at $30.7 \%$ (Figure 6.2). 


\section{Willowbank $10 \mathrm{~cm}$}

- Initial soil moisture was $31 \%$.

- Soil moisture rose from the onset of irrigation to peak after $5 \mathrm{hrs} 20 \mathrm{mins}$ at $33.7 \%$. It then decreased $1.1 \%$ over the next $10 \mathrm{hrs} 45 \mathrm{mins}$.

- Soil moisture showed an immediate response to the second irrigation, rising from $32.6 \%$ to $35.4 \%$ over $2 \mathrm{hrs} 10 \mathrm{~min}$ (including the $10 \mathrm{~min}$ irrigation period).

- Soil moisture then stayed constant for $12 \mathrm{hrs}$ before decreasing $1.5 \%$ over the following $26 \mathrm{hrs} 45 \mathrm{mins}$, to $34 \%$ at the end of the monitoring (Figure 6.3).

\section{Willowbank $20 \mathrm{~cm}$}

- Initial soil moisture was $22.3 \%$.

- Immediately upon irrigation and over the following $15 \mathrm{hrs} 15 \mathrm{mins}$, soil moisture increased $1.7 \%$ to $24 \%$ - where it remained constant for $13 \mathrm{hrs}$ until the second irrigation cycle.

- Soil moisture values showed an immediate, though slight, response to the second irrigation. Over the duration of monitoring - 37hrs $15 \mathrm{~min}$ - soil moisture continued to increase, reaching a maximum of $25.6 \%$. This was equal to the response during the first cycle, of $1.7 \%$ (Figure 6.3).

\section{Willowbank $30 \mathrm{~cm}$}

- Initial soil moisture was $17 \%$.

- This increased to $18 \%$ immediately after the first irrigation and remained constant for 26hrs 30mins until the second irrigation.

- During the second irrigation it increased $1.7 \%$ over $20 \mathrm{mins}$ to $19.7 \%$ where it remained constant $( \pm<1 \%)$ for $36 \mathrm{hrs}$ until the end of the monitoring (Figure 6.3).

\section{Willowbank $40 \mathrm{~cm}$}

- Initial soil moisture was $16.4 \%$.

- There was no discernable effect from either irrigation pass. Soil moisture at the end of the monitoring was $17.2 \%$ (a gradual increase of $0.8 \%$ ).

- This data set had the lowest soil moisture of all depths monitored (Figure 6.3).

\section{Willowbank $60 \mathrm{~cm}$}

- Initial soil moisture was $18.9 \%$ (higher than at depths $40 \mathrm{~cm}$ and $30 \mathrm{~cm}$ ). 
- Soil moisture remains unchanged $( \pm<1 \%)$ by either irrigation pass and soil moisture at the end of monitoring was still at $18.9 \%$ (Figure 6.3).

Willowbank Composite Depths

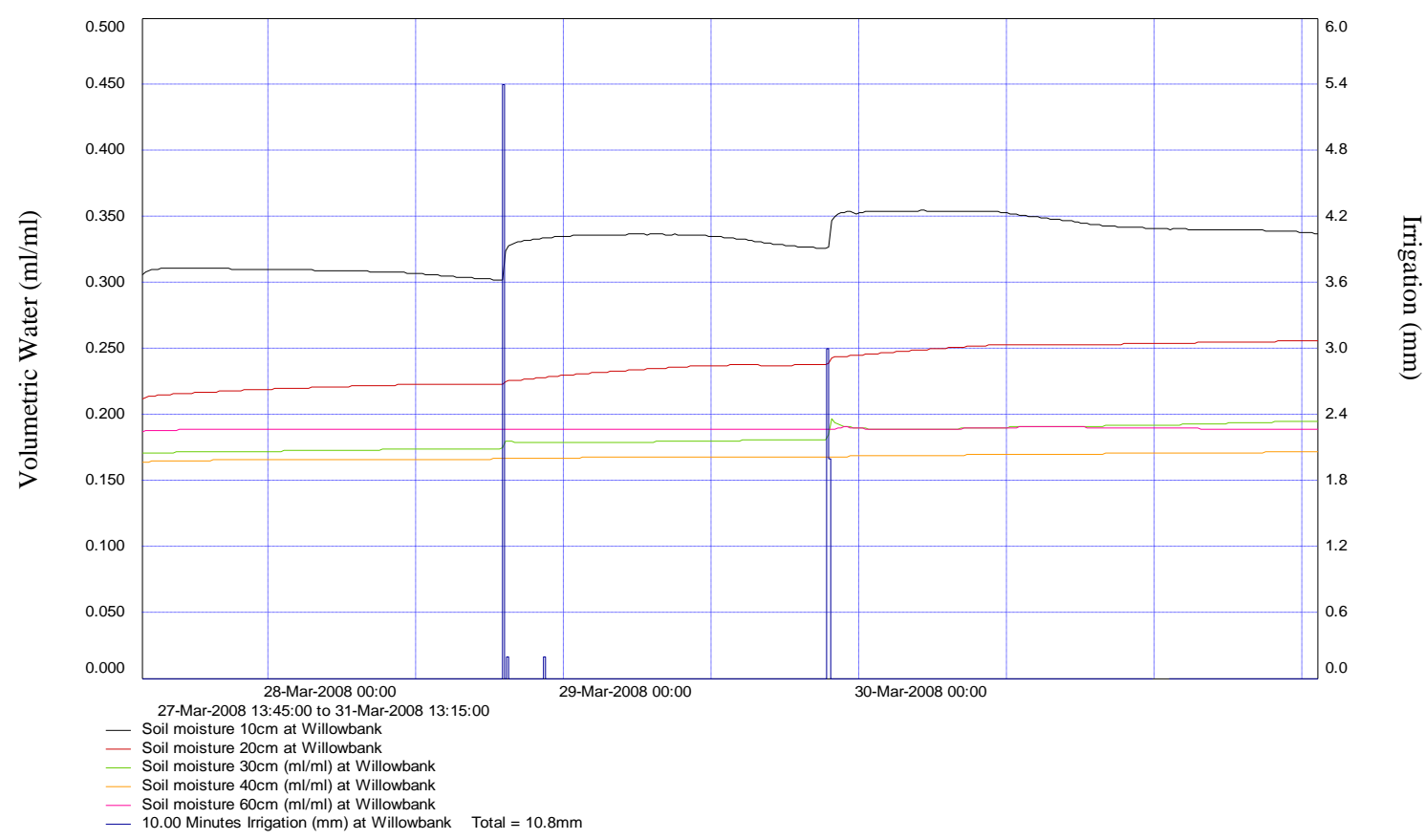

Figure 6.3 Willowbank composite depth soil moisture

Willowbank Profile Average

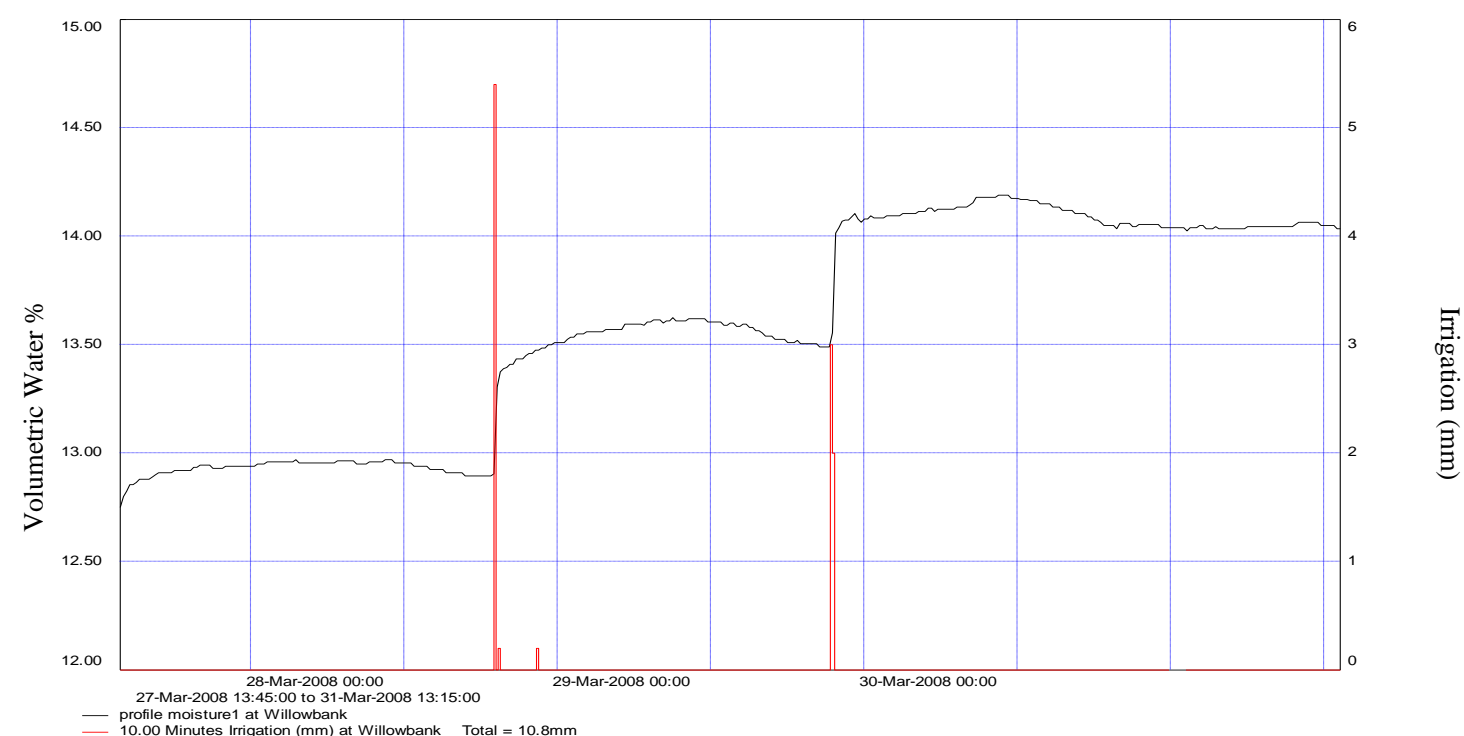

Figure 6.4. Willowbank Profile Moisture - average of probe depths (10,20,20,40 and $60 \mathrm{~cm})$ shown as a volumetric water percentage. 


\subsubsection{Willowbank - Summary of soil response}

The most notable aspect of this site is that soil moisture at depth $40 \mathrm{~cm}$ is the lowest value for all depths (testing went to $60 \mathrm{~cm}$ ) and remains so throughout the test period. Soil moisture at depth $30 \mathrm{~cm}$ is also initially lower than at $60 \mathrm{~cm}$ but increases after the second irrigation period to finish just slightly higher (at 19.6\%) than at depth $60 \mathrm{~cm}$ (at 18.9\%). Soil moisture for the lowest depth $60 \mathrm{~cm}$ remains unchanged by irrigation, however, moisture content is higher or equal to the two next shallower depths. The top two depths respond as would be expected to irrigation of this rate and volume.

\subsection{Holbrook}

Holbrook Station runs sheep/cattle. The field site was under well-established (5 year) centre pivot irrigation. Discussions with the manager revealed early additions of topsoil had occurred in an effort to build up the soil profile. The irrigator speed was increased manually on request between the first and second passes due to time constraints (this, however, also affects application volumes and is reflected in the data). Interestingly, the irrigation volume was assumed by farm management to be greater $(\sim 2 \mathrm{x})$ than was actually recorded. The site was located on a gently sloping, south facing fan surrounded by well-established shelterbelts. Site location E 2312042/ N5677212; Elevation 660 m (a.s.1)

\subsubsection{Soil type - Humose Orthic Brown, Pukaki (series)}

These soils are described by Webb (1992) as well drained, formed from shallow to moderately deep deposits of loess, with a high content of fine sand. They occur on terraces and low angled fans in the moist subhumid $(550-800 \mathrm{~mm})$ region. They are characterised by,

- $\quad 18-25 \mathrm{~cm}$ fine sandy loam to loamy fine sand topsoils with weakly to moderately developed crumb structure.

- Rapid permeability.

- Light olive brown to dark yellowish brown fine sandy loam to loamy fine sand B horizons with weakly developed crumb structure with a tendency to form medium nut or block structure. 
- Friable or very friable consistence in top soils and friable in subsoils.

- Subsoils grading into olive brown very weakly structured $\mathrm{C}$ horizons below $50 \mathrm{~cm}$.

- Stones commonly occur above $80 \mathrm{~cm}$.

The observed soil profile consisted of a friable humose rich topsoil of $10 \mathrm{~cm}$ overlying $30 \mathrm{~cm}$ of olive brown fine sandy loam. This graded rapidly at $40 \mathrm{~cm}$ into an unexpected, compact clay horizon (fragipan) that may be the result of the added topsoil and its subsequent compaction (Figure 6.5). It was significantly compact to impede TDR installation. No Campbell hand-held surface moisture probes $(10 \mathrm{~cm})$ were utilized at this site due to constraints imposed by the timing of irrigation.

Holbrook Soil Profile

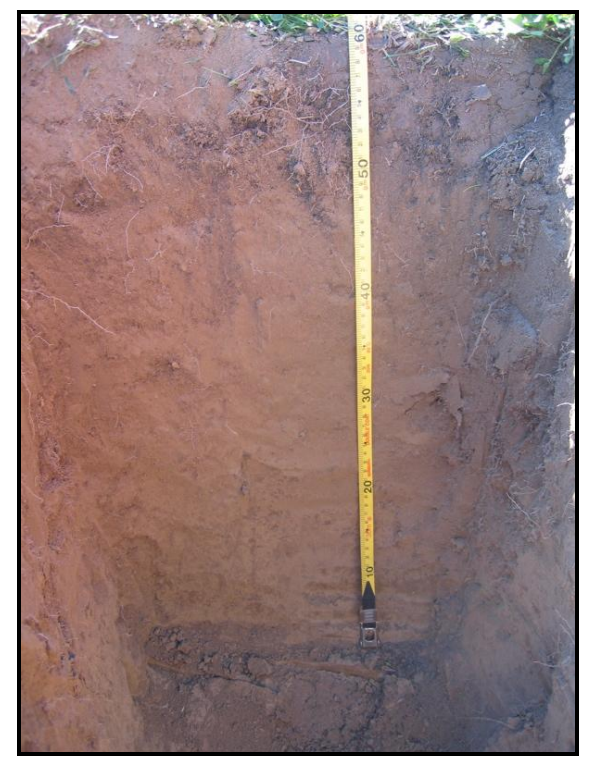

Figure 6.5: Holbrook soil profile.

\subsubsection{Irrigation Overview}

- The probes were in place $2 \mathrm{hrs} 15 \mathrm{~min}$ before the first irrigation pass

- First irrigation began 19:00 $24^{\text {th }}$ March

- ended 19:20 $24^{\text {th }}$ March

- The total applied water during the first application was $7.6 \mathrm{~mm}$ over $20 \mathrm{~min}$

- There were $54 \mathrm{hrs}$ between irrigation passes

- Second irrigation began 1:20 $27^{\text {th }}$ March

- $\quad$ ended 1:30 $27^{\text {th }}$ March

- The total applied water for the second application was $2.8 \mathrm{~mm}$ over $10 \mathrm{~min}$

- Total water over two irrigation cycles within 137 hours was $10.4 \mathrm{~mm}$ (Figure 6.6) 


\subsubsection{Individual depth profiles}

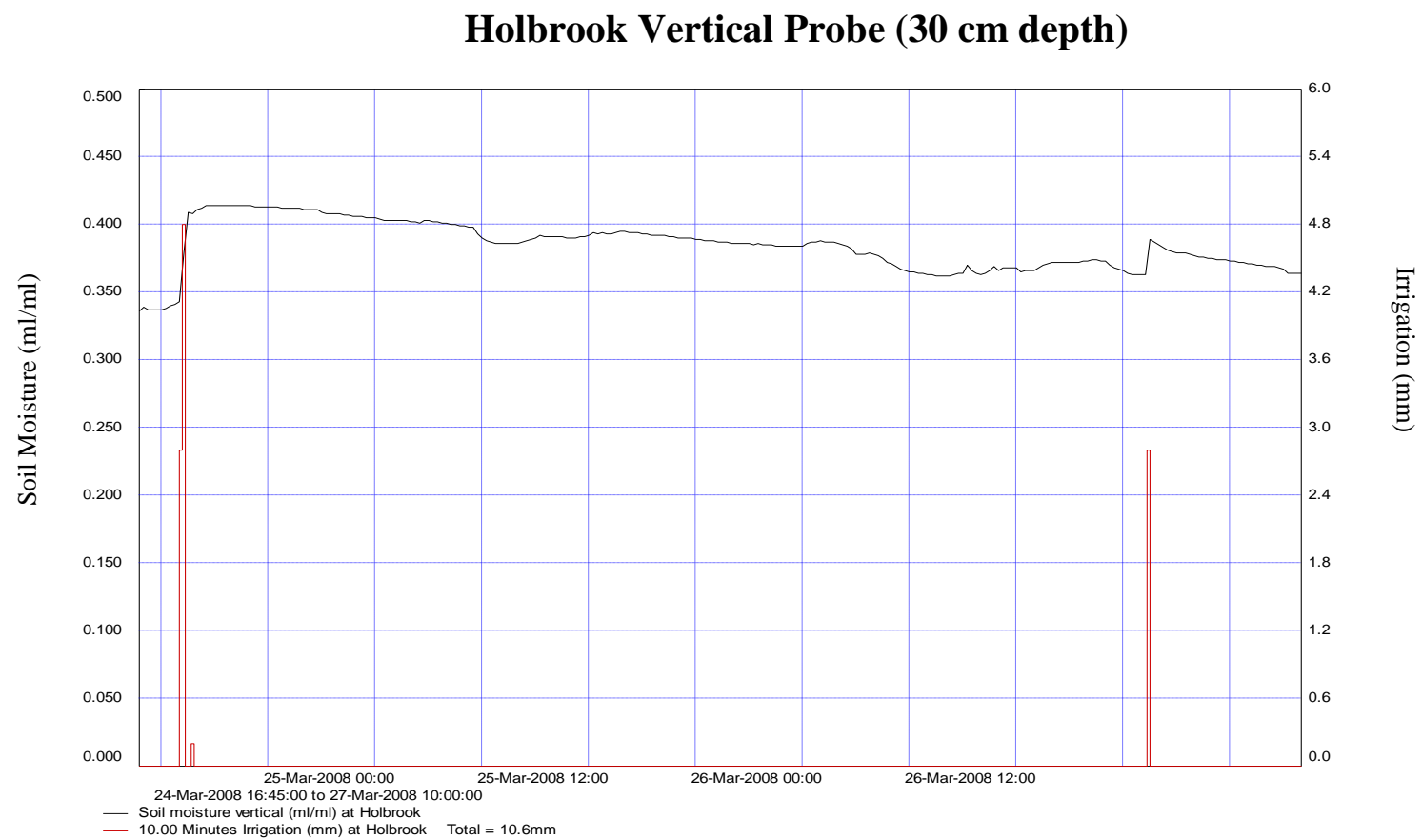

Figure 6.6. Holbrook vertical soil moisture over two irrigation cycles, showing response to moisture in the top $30 \mathrm{~cm}$.

\section{Holbrook Vertical Probe (30 cm depth)}

- Initial soil moisture was $33.6 \%$.

- This increased $7.8 \%$ from the onset of irrigation, over $1 \mathrm{hr} 30 \mathrm{mins}$ to $41.4 \%$.

- $\quad$ The trend then decreased $5.1 \%$ to $36.3 \%$ over $52 \mathrm{hrs} 45 \mathrm{~min}$.

- During the second irrigation pass soil moisture increased $2.6 \%$ to $38.9 \%$ before decreasing $2.5 \%$ over the remaining $8 \mathrm{hrs}$ and $30 \mathrm{mins}$ of monitoring to $36.4 \%$ (Figure 6.6)

\section{Holbrook $10 \mathrm{~cm}$}

- Initial soil moisture was $33.6 \%$.

- This increased by $7.5 \%$ to $40.8 \%$, immediately upon and for $3 \mathrm{hrs}$ after the start of irrigation.

- For the following $54 \mathrm{hrs}$ soil moisture declined $4.5 \%$ to $36.3 \%$ just prior to the second irrigation pass.

- The second pass did not increase soil moisture content but halted the decline and kept it steady at $36.4 \%$ for $9 \mathrm{hrs} 30 \mathrm{~min}$ until the end of monitoring (Figure 6.7) 


\section{Holbrook $20 \mathrm{~cm}$}

- Initial soil moisture content was $29 \%$.

- Soil moisture peaked $15 \mathrm{hrs}$ after the first irrigation pass at $31.2 \%$, an increase of $2.2 \%$.

- The soil moisture then remained constant for $19 \mathrm{hrs} 40 \mathrm{mins}$ before decreasing at a steady rate for $28 \mathrm{hrs}$ to $30.6 \%$ at the end of the data set - a decrease of just $1.4 \%$ (Figure 6.7).

- The second irrigation pass had no discernable impact on the soil moisture at this depth (there is $9 \mathrm{hrs} 30 \mathrm{~min}$ between the last pass and the end of monitoring). This is not surprising given the difference in application volume and duration between the first and second passes ( $7.6 \mathrm{~mm}$ over $20 \mathrm{~min}$ versus $2.8 \mathrm{~mm}$ over $10 \mathrm{~min}$ for the second).

\section{Holbrook $30 \mathrm{~cm}$}

- Initial soil moisture content was $26.2 \%$.

- $30 \mathrm{hrs} 55 \mathrm{~min}$ after irrigation this had increased to $27.7 \%$ - an increase of $1.5 \%$ where it stayed constant for $25 \mathrm{hrs} 45 \mathrm{~min}$.

- This layer unsurprisingly was also not affected by the second irrigation pass (of just $2.8 \mathrm{~mm}$ ) and the remainder of the data shows the soil moisture staying relatively constant. This depth has consistently lower soil moisture content than at greater depths (Figure 6.7).

\section{Holbrook $40 \mathrm{~cm}$}

- Initial soil moisture content was $29.5 \%$.

- From the first irrigation pass and throughout the duration of monitoring the soil moisture remains relatively unaffected. It gradually rises to $30.2 \%$; a change of just $0.7 \%$ at this depth (Figure 6.7).

\section{Holbrook $60 \mathrm{~cm}$}

- Initial soil moisture content was $26.3 \%$.

- Soil moisture remains unchanged by either irrigation pass finishing at $26.6 \%$ at the end of the monitoring (Figure 6.7). 
Holbrook Composite Depths

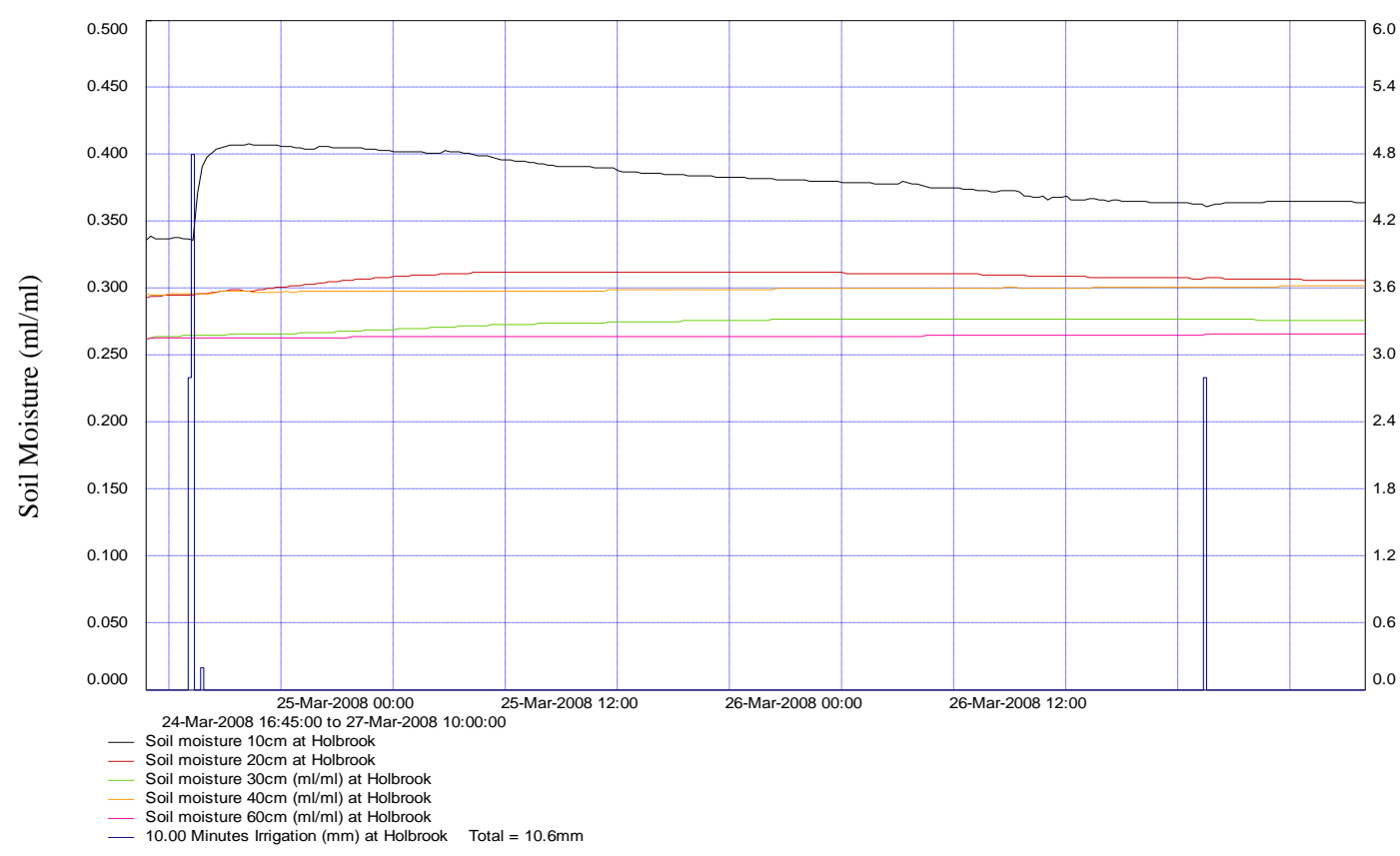

Figure 6.7. Holbrook composite depth soil moisture

Holbrook Profile Average

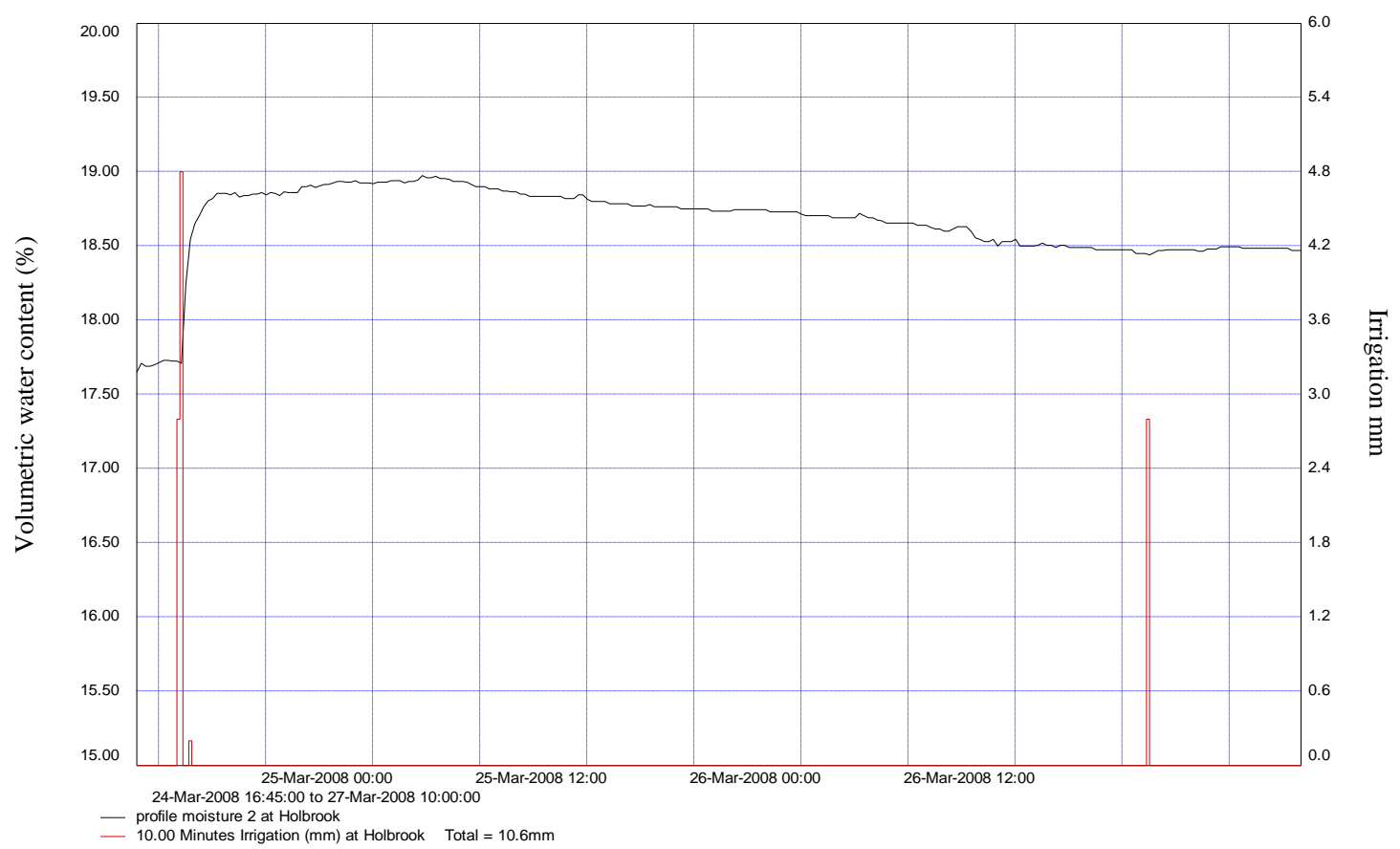

Figure 6.8. Holbrook volumetric water converted to an average percentage over the full profile depth 


\subsubsection{Holbrook - Summary of soil response}

Soil moisture at the deepest two layers $(40 \mathrm{~cm}$ and $60 \mathrm{~cm}$ ) at Holbrook remain unaffected by either irrigation pass - this was expected as the probes at these depths were imbedded in the compacted and impermeable clay layer. Soil moisture at $30 \mathrm{~cm}$ is lower than expected (similar to depth $60 \mathrm{~cm}$ ) and it is also relatively unaffected by irrigation. Soil moisture at $40 \mathrm{~cm}$ (similar to that at $20 \mathrm{~cm}$ ) also shows no response to irrigation but again the probe was within the boundary of the clay layer. Soil moisture at $20 \mathrm{~cm}$ is mildly affected by irrigation, but maintains its moisture levels well and moisture levels at $10 \mathrm{~cm}$ show a rapid response to the first irrigation pass $(7.6 \mathrm{~mm})$ though less, as expected, to the second $(2.8 \mathrm{~mm})$. Clearly the irrigation volumes applied during the test are minimal with little or no changes to soil moisture apparent at lower depths. In spite of this, Holbrook had the second highest initial soil moisture of all the sites (Figure 6.8).

\subsection{Bendrose}

Bendrose Station runs cattle/sheep. It is adjacent to the Twizel River and is a third generation farm with well-established shelterbelts. The monitoring site was level and approximately $1 \mathrm{~km}$ east of the Twizel River bed.

Site Location E2281148 / N5656836; Elevation 448 m (a.s.1)

\subsubsection{Soil Type - Humose Orthic Brown earth, Mackenzie (series)}

These soils are described by Webb, as being "predominantly shallow and stony, excessively to somewhat excessively drained soils formed from sandy fluvio-glacial gravels overlain by varying thicknesses of alluvium.... they form on the intermediate terraces and fans of the dry subhumid region" (1992:47). Characteristically they:

- Have $5-18 \mathrm{~cm}$ sandy loam to very stony loamy sand topsoils with weakly to very weakly developed crumb and granular structure.

- Have yellowish brown to olive brown, sandy loam to very stony loamy sand B horizons with weakly to very weakly developed nut and crumb structure. 
- Have subsoils grading into light yellowish brown, structureless, very stony sand C horizons below $30 \mathrm{~cm}$.

- Have very friable consistency.

- And have rapid permeability.

The observed soil profile showed a slightly darker topsoil in the first $10 \mathrm{~cm}$ before lightening to a uniformly yellowish brown sandy loam with a friable texture and grading at depth $40 \mathrm{~cm}$ to a stony (clasts $>5 \mathrm{~cm}$ ) structureless sand (Figure 6.9). Campbell hand-held surface moisture probes (length $10 \mathrm{~cm}$ ) gave an average soil moisture content of $9.1 \%$. This was the lowest of all site surface readings.

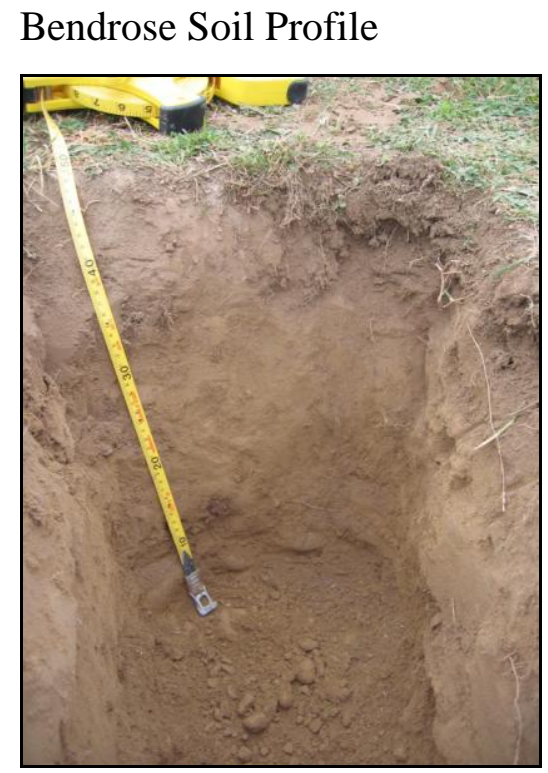

Figure 6.9. Bendrose soil profile showing depth to stony layer

\subsubsection{Irrigation Overview}

- The probes were in place for $12 \mathrm{hrs} 5 \mathrm{mins}$ before the first irrigation pass

- First irrigation began 5:20 $28^{\text {th }}$ March

- ended 6:10 $28^{\text {th }}$ March

- The total water applied during the first application was $6.6 \mathrm{~mm}$ over 50min

- There were $39 \mathrm{hrs} 15 \mathrm{mins}$ between irrigation cycles

- Second irrigation began 22:30 $29^{\text {th }}$ March

- ended 23:40 29 $9^{\text {th }}$ March

- The total applied water for the second application was $7.9 \mathrm{~mm}$ over $70 \mathrm{~min}$

- Bendrose had the slowest application rates of all the sites

- Total water for two irrigation cycles within 89 hours was 14.5 mm (Figure 6.10) 


\subsubsection{Individual depth profiles}

Bendrose Vertical Probe $(30 \mathrm{~cm}$ depth)

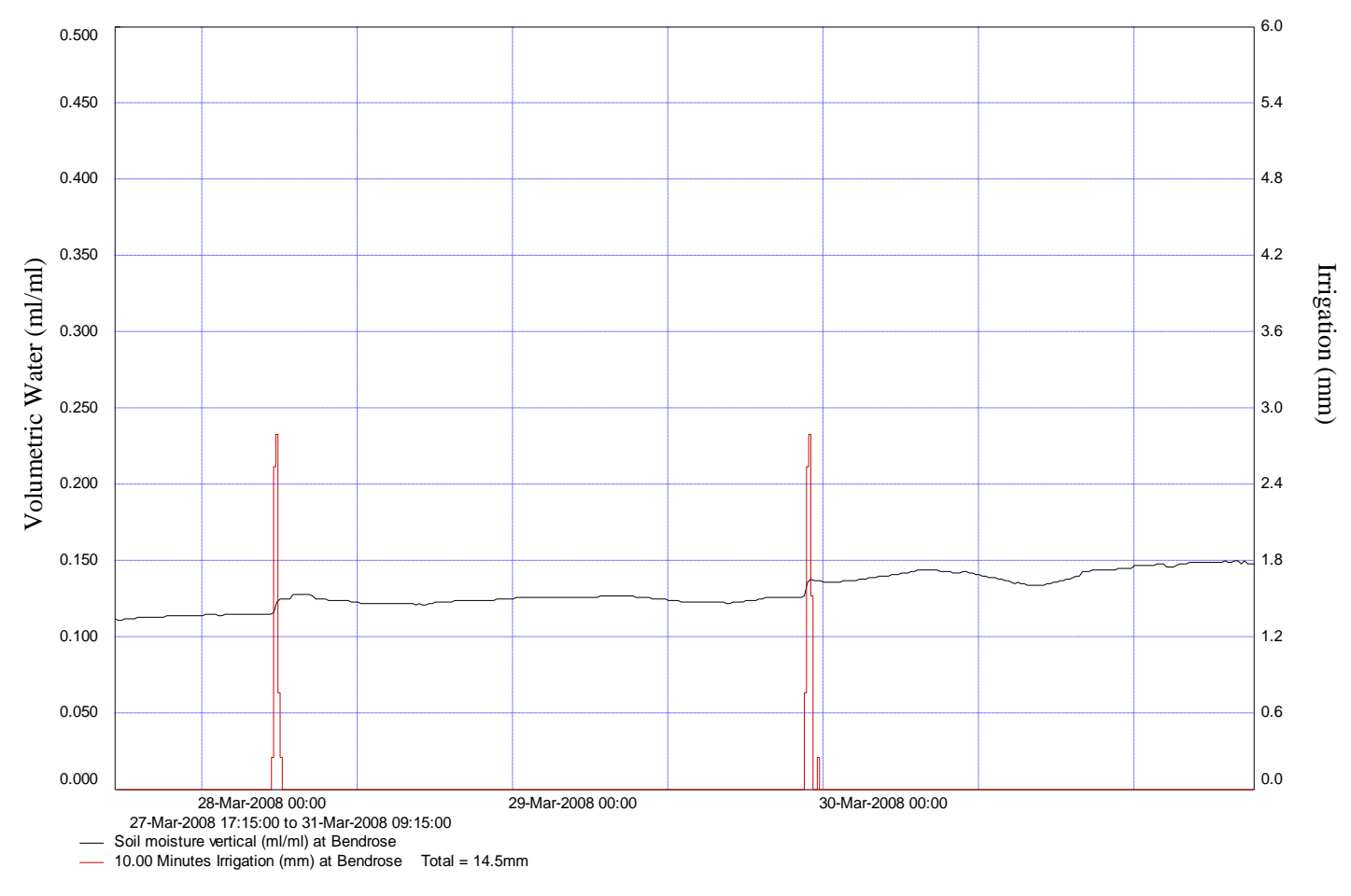

Figure 6.10. Bendrose Vertical

\section{Bendrose Vertical $(30 \mathrm{~cm}$ probe depth)}

- The initial soil moisture content was $11.2 \%$.

- After irrigation, soil moisture increased $1.6 \%$ over $1 \mathrm{hr} 40 \mathrm{~min}$ to $12.8 \%$. It then stayed relatively constant $( \pm<1 \%)$ until the second irrigation.

- During the second irrigation, soil moisture rose $1 \%$ to $13.8 \%$ and continued to rise over the following $7 \mathrm{hrs} 30 \mathrm{~min}$ to $14.4 \%$.

- A $1 \%$ decrease in soil moisture over the next $8 \mathrm{hrs}$ to $13.4 \%$ was followed by an increase of $1.6 \%$ over $15 \mathrm{hrs}$ and $30 \mathrm{~min}$ to a maximum of $15 \%$ (Figure 6.10 ).

\section{Bendrose $20 \mathrm{~cm}$}

- Initial soil moisture content was $12.2 \%$.

- During the first irrigation pass soil moisture began to increase and slowly rose $1 \%$ $( \pm 0.2 \%)$ to $13.2 \%$ until the second irrigation.

- During the second irrigation pass the soil moisture increased $1.7 \%$ to $14.9 \%$ where it remained constant $( \pm<1 \%)$ until the end of monitoring (Figure 6.11). 


\section{Bendrose $30 \mathrm{~cm}$}

- The initial soil moisture content was $12.7 \%$.

- This depth showed an initial decrease of $0.3 \%$ during irrigation. An hour later, it was back to $12.7 \%$. From there slowly increased $(<1 \%)$ over the following $39 \mathrm{hrs} 30 \mathrm{~min}$ to $13.3 \%$.

- The second irrigation showed an immediate response at this depth with soil moisture increasing $1.2 \%$ over the following $10 \mathrm{hrs} 15 \mathrm{mins}$ to $14.5 \%$ this fluctuated but slowly increased to $15.1 \%$ at the end of the data set (Figure 6.11).

\section{Bendrose $40 \mathrm{~cm}$}

- Initial soil moisture content was $12.5 \%$.

- This falls during irrigation to $12.3 \%$ and rises to $12.8 \%, 50$ min after irrigation; an increase of just $0.5 \%$ over $50 \mathrm{~min}$, soil moisture content then remains constant.

- After the second irrigation pass the moisture content rises over $10 \mathrm{hrs} 45 \mathrm{~min}$ to $14.4 \%$. It then drops for $4 \mathrm{hrs} 30 \mathrm{mins}$ to $13.7 \%$, a decrease of $0.7 \%$.

- Following this the trend reverses and soil moisture increases once more for $18 \mathrm{hrs}$ to a peak of $15 \%$ at the end of monitoring (Figure 6.11).

\section{Bendrose Composite Depth}

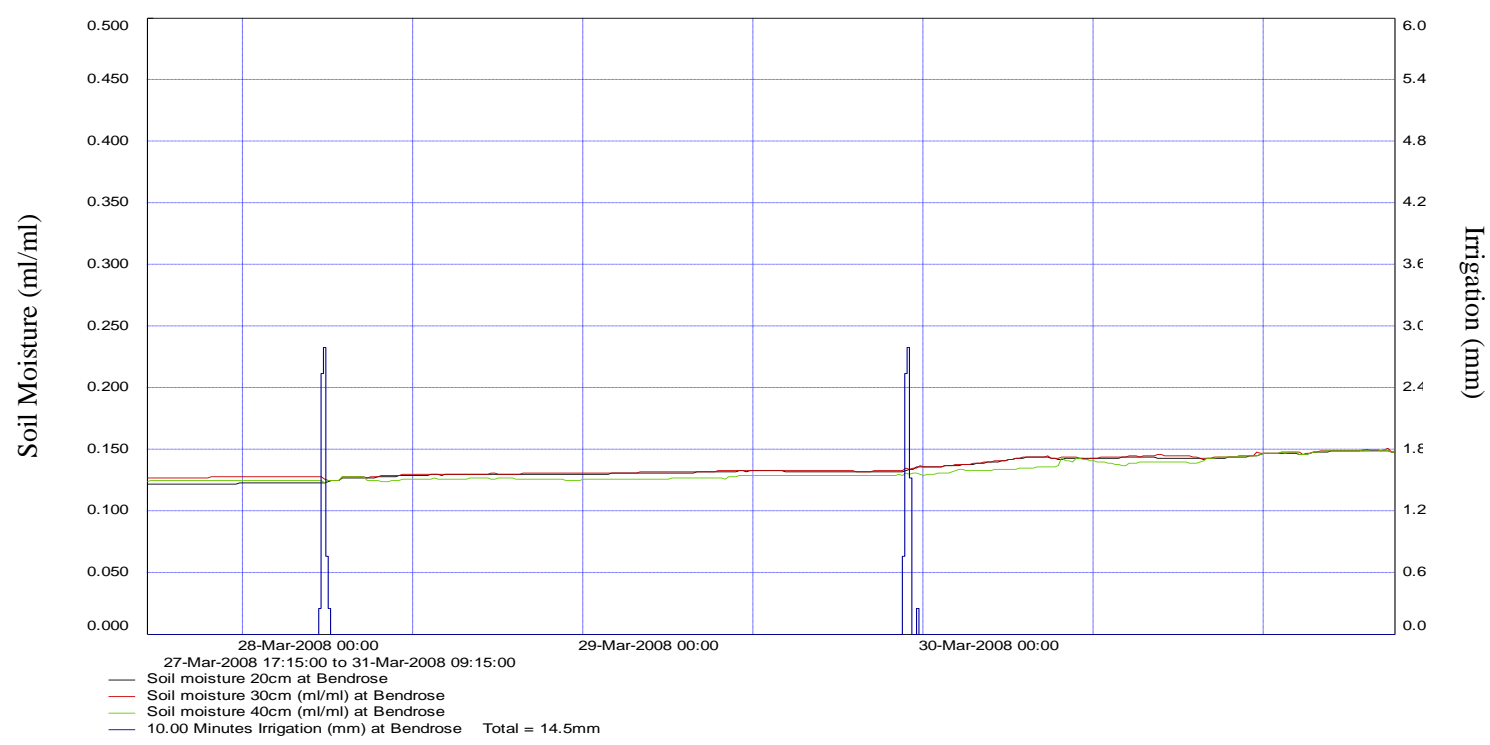

Figure 6.11. Bendrose composite depth soil moisture 
Bendrose profile average

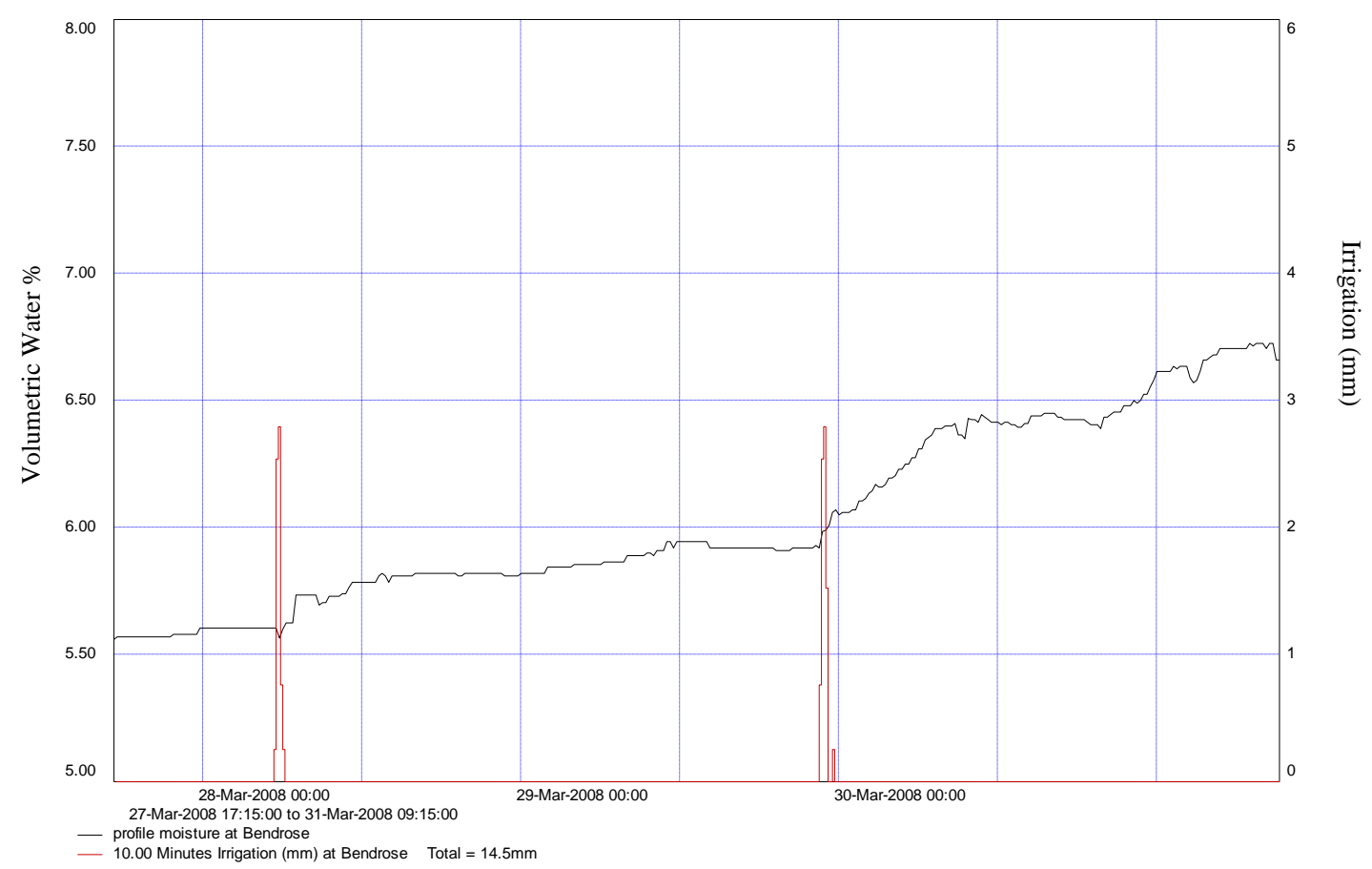

Figure 6.12. Bendrose - total profile moisture average as a percentage.

\subsubsection{Summary of soil response}

At all depths at this site, soil moisture drops in the last $30 \mathrm{~min}$ of monitoring by $\sim 0.2 \%$ which may indicate the end of the effect of irrigation. The apparent fluctuations throughout the data (Figure 6.12) could be interpreted as moisture "surges" as water is transmitted via the soil macropores. It then takes another 3-4hrs following irrigation for the water transmitted via the soil matrix to arrive at depth - and that water continues to be transmitted at a steady rate.

Prior to irrigation the soil moisture at the $10 \mathrm{~cm}$ depth is less than that at $30 \mathrm{~cm}$ and $40 \mathrm{~cm}$. However, after the first irrigation cycle the soil moisture at $20 \mathrm{~cm}$ and $30 \mathrm{~cm}$ become similar and have lower values than the $10 \mathrm{~cm}$ layer above (Figure 6.11). This was the only site where soil moisture dropped $(<1 \%)$ during irrigation and the soil had the slowest response time to irrigation. This could be linked to the duration of the irrigation pass (50 min versus 20-30 min for most other sites) and the volumes of water applied. The decrease in moisture during irrigation is however unique and will be discussed further in Chapter 7. 


\subsection{Wairepo}

Wairepo is the only site situated on dairying land. This site was chosen to compare the same soils (Mackenzie series, at Bendrose site above) under different land use. The area has been under irrigation for five years and is currently undergoing intensification (field obs.). The site was located just south of and adjacent to Lake Ruataniwha on a south sloping terrace. This site exhibited lush pasture growth (Figure 6.13)

Site Location E2276080 / N5653342; Elevation 477m (a.s.1)

\subsubsection{Soil Type - Humose Orthic Brown earth, Mackenzie (series)}

As above for the Bendrose site, these soils are described by Webb (1992) as being "predominantly shallow and stony, excessively to somewhat excessively drained soils formed from sandy fluvio-glacial gravels overlain by varying thicknesses of alluvium.... they form on the intermediate terraces and fans of the dry subhumid region”. Characteristically they,

- Have 5-18 cm sandy loam to very stony loamy sand topsoils with weakly to very weakly developed crumb and granular structure.

- Yellowish brown to olive brown, sandy loam to very stony loamy sand B horizons with weakly to very weakly developed nut and crumb structure.

- Subsoils grading into light yellowish brown, structureless, very stony sand C horizons below $30 \mathrm{~cm}$.

- Very friable consistence throughout.

- Rapid permeability.

The observed soil profile contained lush pasture growth on $12 \mathrm{~cm}$ of dark humose loam topsoil, which by $20 \mathrm{~cm}$ was a yellowish brown very stony loamy sand B horizon. The stone content and size increased with depth $(\sim 5-10 \mathrm{~cm})$, which by depth $70 \mathrm{~cm}$ had abruptly become grey river gravels $(<5 \mathrm{~cm})$ and fines (Figure 6.13). Campbell hand-held surface moisture probes (length $10 \mathrm{~cm}$ ) gave an average soil moisture content of $27.9 \%$. 


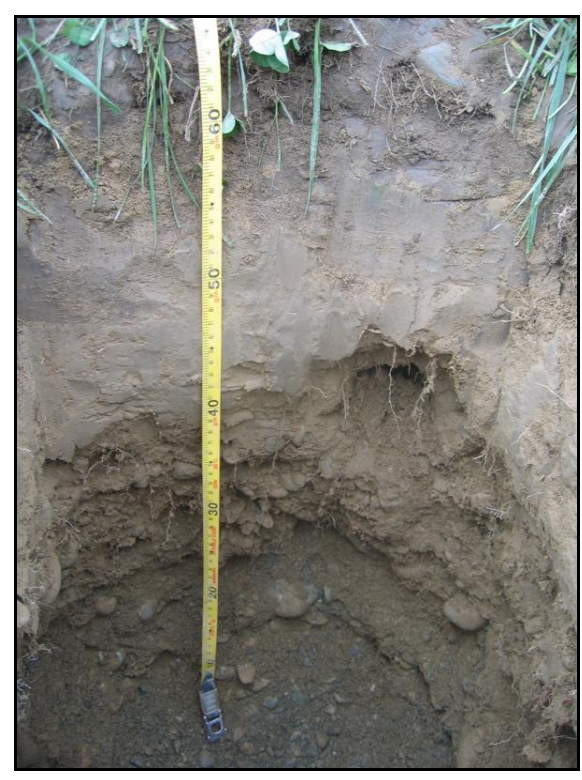

Figure 6.13.Wairepo soil profile showing depth to gravel.

\subsubsection{Irrigation overview}

- The probes were in place $27 \mathrm{hrs}$ before the first irrigation pass

- First irrigation began 15:50 $1^{\text {st }}$ April

- ended 16:10 $1^{\text {st }}$ April

- The total water applied during the first irrigation was $5.6 \mathrm{~mm}$ over $20 \mathrm{~min}$.

- There were 6 hrs $30 \mathrm{~min}$ between irrigation cycles

- Second irrigation began 22:40 $1^{\text {st }}$ April

- ended 23:10 $1^{\text {st }}$ April

- The total applied water for the second irrigation was $6.6 \mathrm{~mm}$ over $30 \mathrm{~min}$.

Total water over two irrigation cycles within 47 hours was $12.2 \mathrm{~mm}$ (Figure 6.14).

\subsubsection{Individual depth profiles}

\section{Wairepo vertical $(30 \mathrm{~cm})$}

- Initial soil moisture content was $30 \%$.

- An increase in soil moisture of $2.6 \%$ after the first irrigation pass to $32.6 \%$. This was echoed by the second pass (6hrs 30 min later), producing a further $2.4 \%$ increase in soil moisture to $35 \%$.

- Soil moisture remained fairly constant until the end of the data set approximately 12 hrs later where it had dropped just $1.7 \%$ to $33.3 \%$ (Figure 6.14) 


\section{Wairepo Vertical Probe $(30 \mathrm{~cm})$}

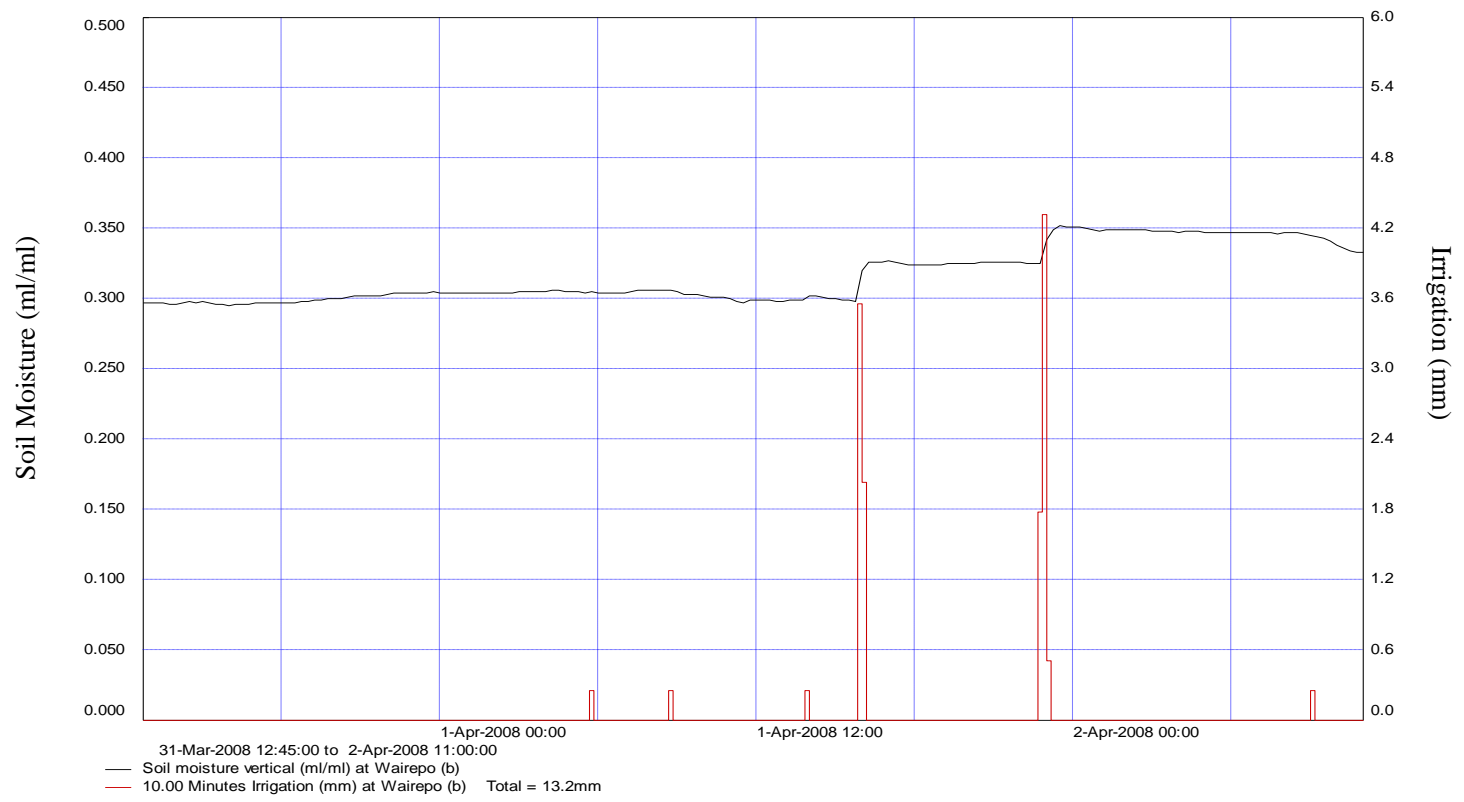

Figure 6.14. Wairepo vertical probe graph showing moisture response to irrigation and content in the top $30 \mathrm{~cm}$.

\section{Wairepo $15 \mathrm{~cm}$}

- Initial soil moisture content was $34 \%$.

- Soil moisture increased $1.5 \%$ after the first irrigation pass to $35.3 \%$.

- The second pass $6 \mathrm{hrs} 30$ min later produced a further $2 \%$ increase in soil moisture to $37.3 \%$. This remained constant until the end of monitoring approximately $12 \mathrm{hrs}$ later (Figure 6.15).

\section{Wairepo $30 \mathrm{~cm}$}

- Initial soil moisture content was $36.9 \%$.

- Soil moisture increased $1.6 \%$ after the first irrigation pass to $38.5 \%$.

- The second pass, $6 \mathrm{hrs} 30$ min later produced a further $2.1 \%$ increase in soil moisture to $40.6 \%$. The moisture content remained constant until the end of monitoring approximately $12 \mathrm{hrs}$ later (Figure 6.15).

\section{Wairepo $40 \mathrm{~cm}$}

- Initial soil moisture content was $11.7 \%$.

- No observable change in soil moisture from the first irrigation pass. Second pass 6hrs 30 min later produced a "spike" to $46.2 \%$.

- Soil moisture drops after irrigation over the following $45 \mathrm{~min}$ to $29.5 \%$ and continues to drop over $12 \mathrm{hrs}$ to $25.5 \%$ (Figure 6.15 ). 


\section{Wairepo $60 \mathrm{~cm}$}

- Initial soil moisture content was $13 \%$.

- No observable change in soil moisture from the first irrigation pass. Second pass 6hrs 30 min later produced a "spike" to $35.9 \%$.

- Soil moisture drops after irrigation over the following $45 \mathrm{~min}$ to $32 \%$ and continues to drop over $12 \mathrm{hrs}$ to $27.5 \%$ (Figure 6.15 ).

\section{Wairepo $70 \mathrm{~cm}$}

- Initial soil moisture content was $8 \%$

- No observable change in soil moisture from the first irrigation pass. Second pass (6hrs 30 min later) produced a "spike" from $24.6 \%$ to $32.6 \%$.

- Soil moisture drops after irrigation over the following $45 \mathrm{~min}$ to $20 \%$ and continues to drop over $12 \mathrm{hrs}$ to $16 \%$ (Figure 6.15 )

\section{Wairepo composite depths}

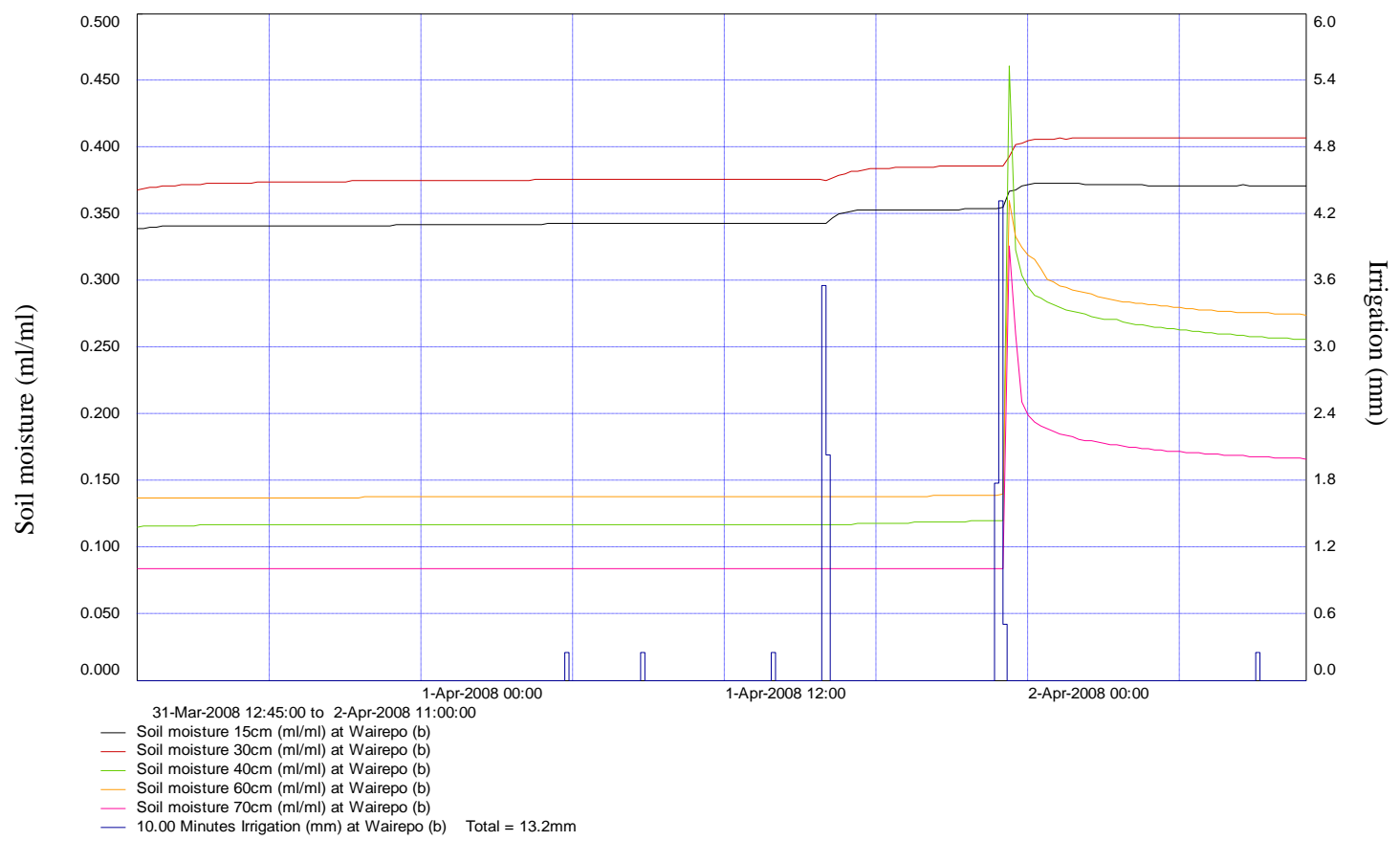

Figure 6.15. Wairepo composite soil moisture showing all depths response to irrigation. 


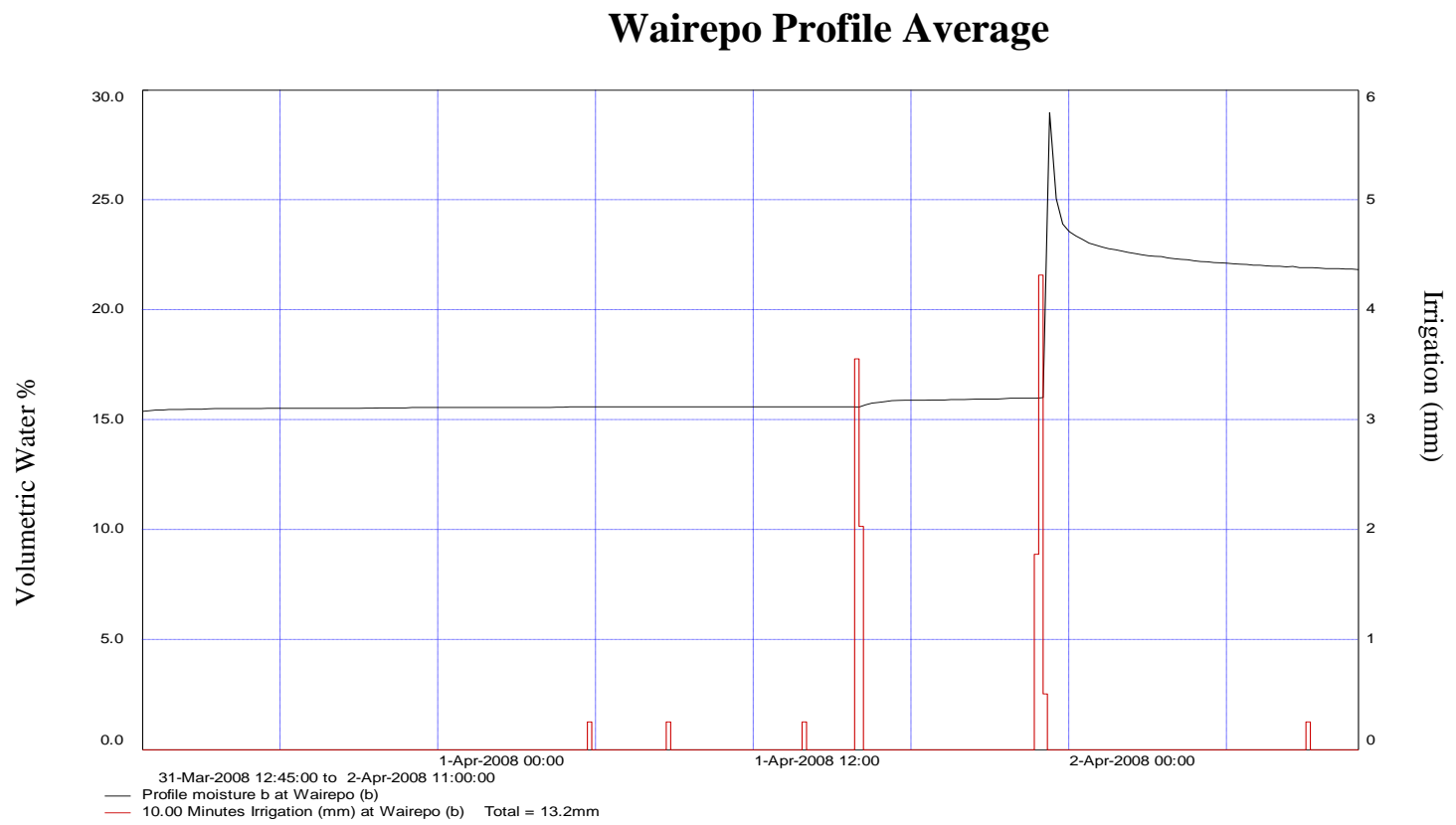

Figure 6.16. Wairepo profile moisture average - all depths averaged and converted to a percentage

\subsubsection{Summary of soil response}

The site at Wairepo shows the most marked response to irrigation of all the sites (Figure 6.16). Soil moisture stays relatively constant at all depths until irrigation, and only increases slightly in the top $20 \mathrm{~cm}$ after the first irrigation pass. During the second irrigation pass, 6hrs 30min later, soil moisture at depths 40, 60 and $70 \mathrm{~cm}$ spikes markedly, then soil moisture drops to roughly twice the value it was prior to irrigation. The data clearly show drainage occurring from the bottom of the soil profile. Soil moisture at depth 15 and $20 \mathrm{~cm}$ does not show this pattern and remains relatively constant throughout both irrigation passes, increasing equally with each pass (figure 6.15).

This chapter has displayed the raw fieldwork data, the following chapter discuses the field data in greater detail. It provides an analysis of the soil moisture trends and what may be inferred from the field monitoring. 


\section{Chapter 7 - Results}

This chapter provides an interpretation of the data presented in the Chapter 6. It starts at the site with the lowest irrigation depth and proceeds to the highest; they are (Holbrook $10.6 \mathrm{~mm}$; Willowbank $11 \mathrm{~mm}$; Wairepo $13.2 \mathrm{~mm}$ and Bendrose $14.5 \mathrm{~mm}$ ). It will compare sites and make a comment about the soil response to moisture and the efficiency of the irrigation regimes.

As an initial observation, it is clear the overall soil moisture values are low for all sites except Wairepo (the only site under dairying). However it is important to note that at the time the fieldwork was conducted $\left(24^{\text {th }}\right.$ March $-2^{\text {nd }}$ April) the growing season for this area was almost at an end (because of the elevation of the basin). Most farmers acknowledged they were no longer "growing grass but just keeping it green" (pers. comm.) and a frost occurred the day after fieldwork was completed indicating the effective end of the growing season and hence the need for irrigation.

Table 2 summarises the irrigation volumes and duration for each site as well as the times between irrigation cycles. From this it is clear that while the volumes are reasonably similar there is a wide variation in both the rate of application and the frequency of irrigation - the speed with which the centre-pivot completes its cycle.

\begin{tabular}{|c|c|c|c|c|c|c|}
\hline Site Name & $\begin{array}{c}\text { Application } \\
\text { volume }(\mathrm{mm}) \text { - } \\
\text { first }\end{array}$ & $\begin{array}{c}\text { Duration of } \\
\text { first } \\
\text { irrigation } \\
\text { (min) }\end{array}$ & $\begin{array}{c}\text { Application } \\
\text { volume }(\mathrm{mm}) \text { - } \\
\text { second }\end{array}$ & $\begin{array}{l}\text { Duration of } \\
\text { second } \\
\text { irrigation (min) }\end{array}$ & $\begin{array}{c}\text { Time } \\
\text { between } \\
\text { applications } \\
\text { (hrs) }\end{array}$ & $\begin{array}{c}\text { Total water } \\
\text { (mm) / Time }(\mathrm{h}) \\
\text { of dataset }\end{array}$ \\
\hline Holbrook & $7.8 \mathrm{~mm}$ & $20 \mathrm{~min}$ & $2.8 \mathrm{~mm}$ & $10 \mathrm{~min}$ & $54 \mathrm{hr}$ & $10.6 \mathrm{~mm} / 137 \mathrm{hr}$ \\
\hline Willowbank & $5.8 \mathrm{~mm}$ & $12 \mathrm{~min}$ & $5.0 \mathrm{~mm}$ & $20 \mathrm{~min}$ & $25 \mathrm{hr}$ & $10.8 \mathrm{~mm} / 95 \mathrm{hr}$ \\
\hline Wairepo & $5.6 \mathrm{~mm}$ & $20 \mathrm{~min}$ & $6.6 \mathrm{~mm}$ & $30 \mathrm{~min}$ & $6.5 \mathrm{hr}$ & $12.4 \mathrm{~mm} / 47 \mathrm{hr}$ \\
\hline Bendrose & $6.6 \mathrm{~mm}$ & $50 \mathrm{~min}$ & $7.9 \mathrm{~mm}$ & $40 \mathrm{~min}$ & $40 \mathrm{hr}$ & $14.5 \mathrm{~mm} / 89 \mathrm{hr}$ \\
\hline
\end{tabular}

Table 2. Summary of individual site irrigation data

While this is partly a factor of the site location with respect to the end point of the centrepivot's arc, it is also governed by the speed the irrigator travels, as indicated by the duration of irrigation application (Bendrose versus Holbrook, Willowbank and Wairepo) (Table 2). 


\subsection{Interpretation}

\section{Holbrook}

Holbrook was the first site instrumentation was installed. It was installed at one end of the centre pivot's arc - just prior ( 2 hours) to the irrigator passing over the site. A check of the rain gauge after the first irrigation pass revealed less water had been applied than the system was calibrated to supply ( $7.6 \mathrm{~mm}$ actual versus $14 \mathrm{~mm}$ expected). Due to time constraints the centre-pivot's speed was increased to ensure a second pass occurred within the monitoring timeframe, although this also reduced the amount of water applied, down to $2.8 \mathrm{~mm}$ (again approximately half what was expected). Regardless of this the return time for this site was the longest for all sites, at 54 hours.

In spite of receiving the least irrigation depth (total $10.4 \mathrm{~mm}$ ) and having the longest gap between irrigation passes (54hrs), Holbrook had the second highest profile average moisture content of all sites. That is, all the probes moisture contents extrapolated over their range of influence and averaged. The top $30 \mathrm{~cm}$ of the profile, as shown by the vertical probe, had a moisture content of just over $40 \%$ after the first irrigation pass. This was maintained, decreasing just $2.5 \%$, until the end of the monitoring (Figure 7.1). This upper profile moisture content reading was exceeded only by Wairepo.

Holbrook Vertical Probe (30 cm depth)

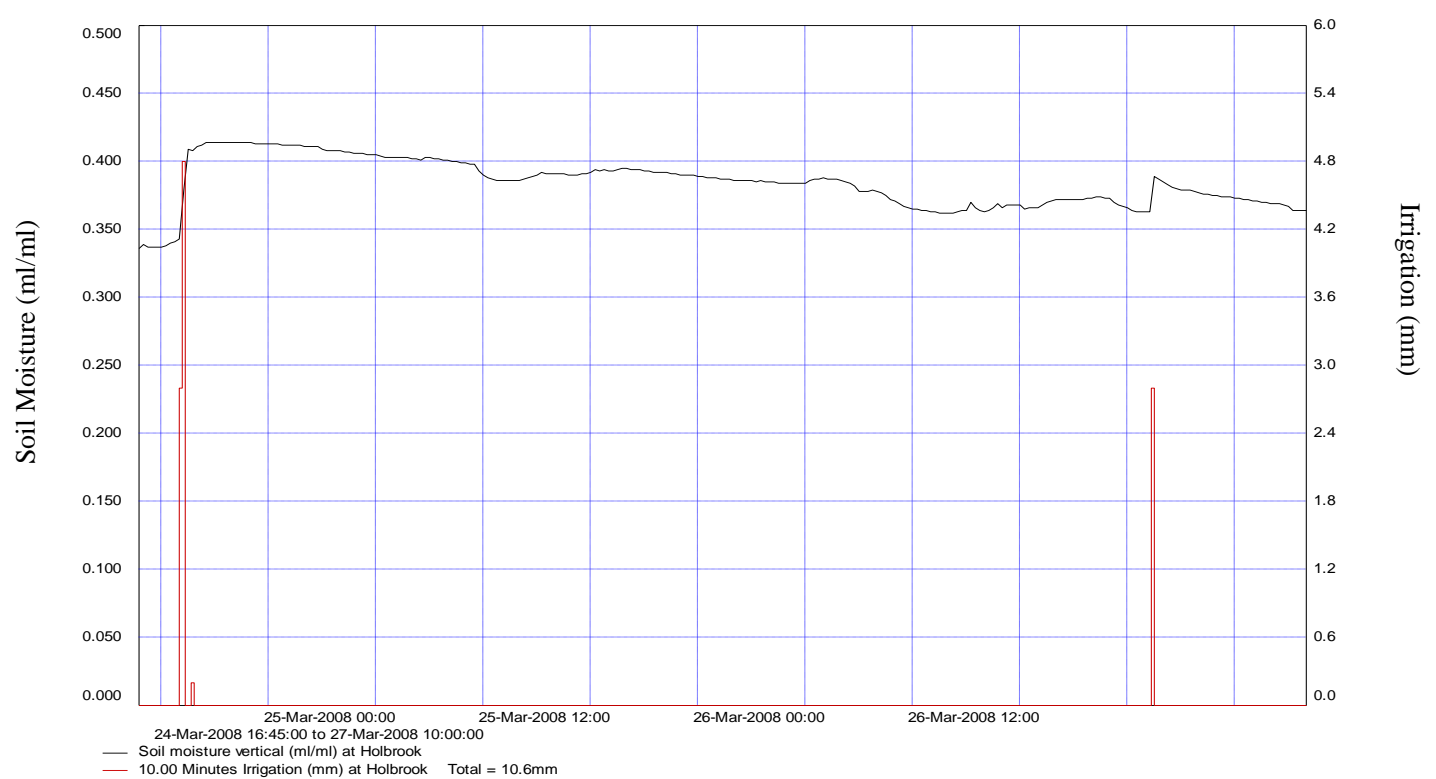

Figure 7.1. Holbrook, vertical soil moisture over two irrigation cycles, showing response to moisture in the top $30 \mathrm{~cm}$. 
Interestingly, the soil moisture at $30 \mathrm{~cm}$ is much lower than that of the rest of the profile. It is similar to that at a depth of $60 \mathrm{~cm}$ (Figure 7.2). This indicates the root zone is relatively water poor and this clearly has implications for optimising plant growth.

However, as discussed in Chapter 5.4 - during installation Holbrook revealed a compact clay layer and that uncharacteristically high clay content may be enough to increase the bound water content which then, as discussed in Chapter 5.1 affects the permittivity and gives a higher than actual soil moisture reading (Robinson et al., 2003). Therefore the soil moisture values at this site should be treated with caution.

\section{Holbrook Composite Depths}

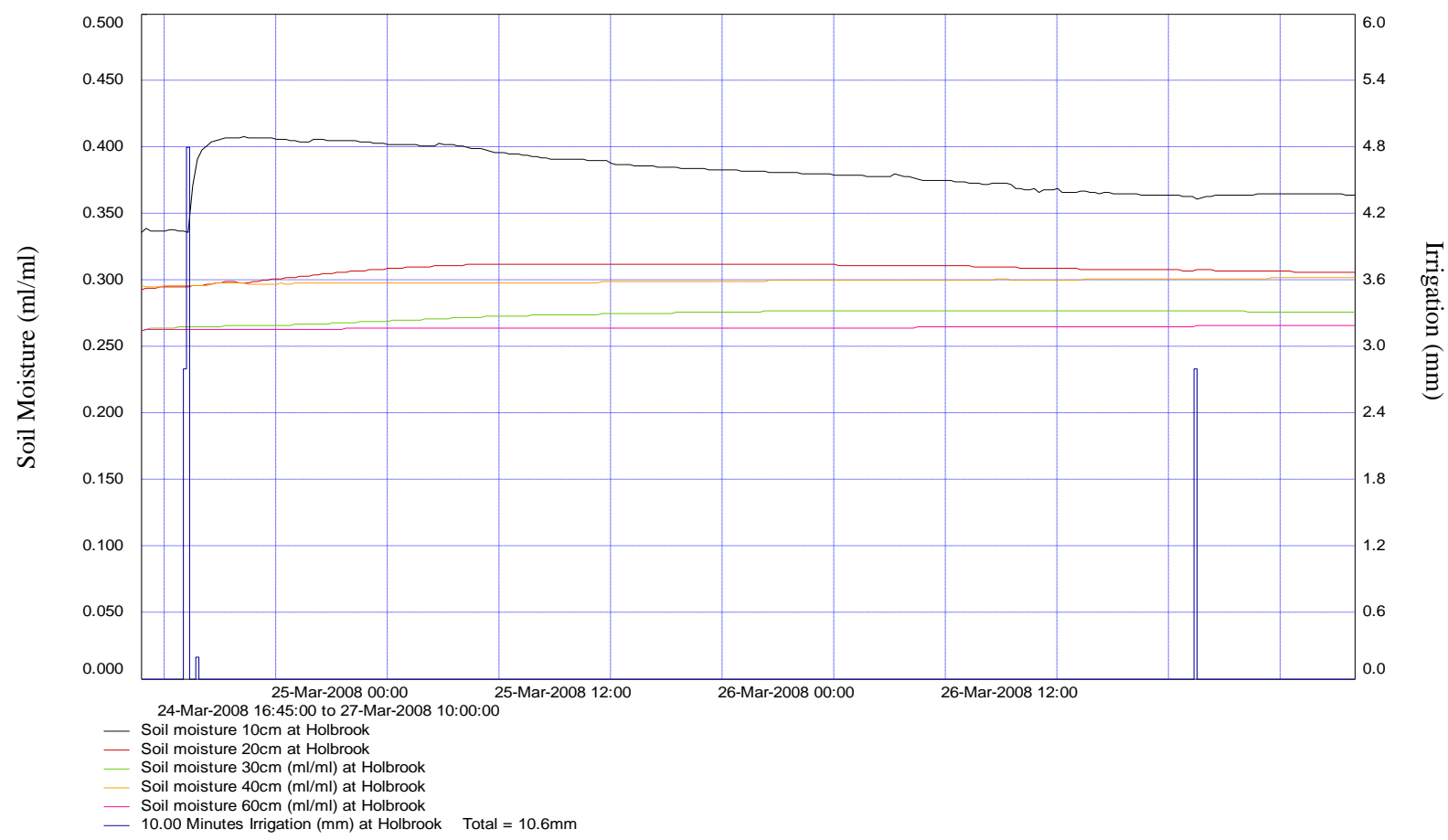

Figure 7.2. Holbrook composite depth soil moisture

Regardless of the actual values it is clear from the composite depth graph (Figure 7.2) that Holbrook is effective at holding soil moisture and that irrigation volumes and rates (at this time) were adequate for pasture growth (Figure 7.3) and that water use is not excessive with little or no percolation through the soil profile. Higher rates of water application (such as, if the land-use were to change to dairying) may perhaps result in ponding from poor drainage resulting from the clay layer. 


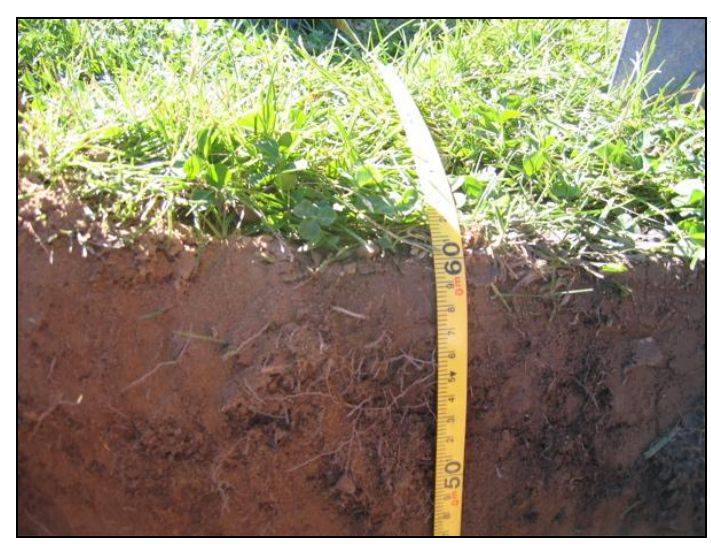

Figure 7.3. Holbrook pasture growth.

\section{Willowbank}

Willowbank had the next lowest irrigation depth $(10.6 \mathrm{~mm})$ with $25 \mathrm{hrs}$ between irrigation cycles. It also had the next lowest average profile moisture content at just under 13\% (Figure 7.4). This rose with irrigation to $13.5 \%$ and then to $14 \%$ after the second irrigation cycle. This change is approximately $5 \%$ less than at Holbrook, although both sites received similar depths of water.

\section{Willowbank -Average Profile Moisture}

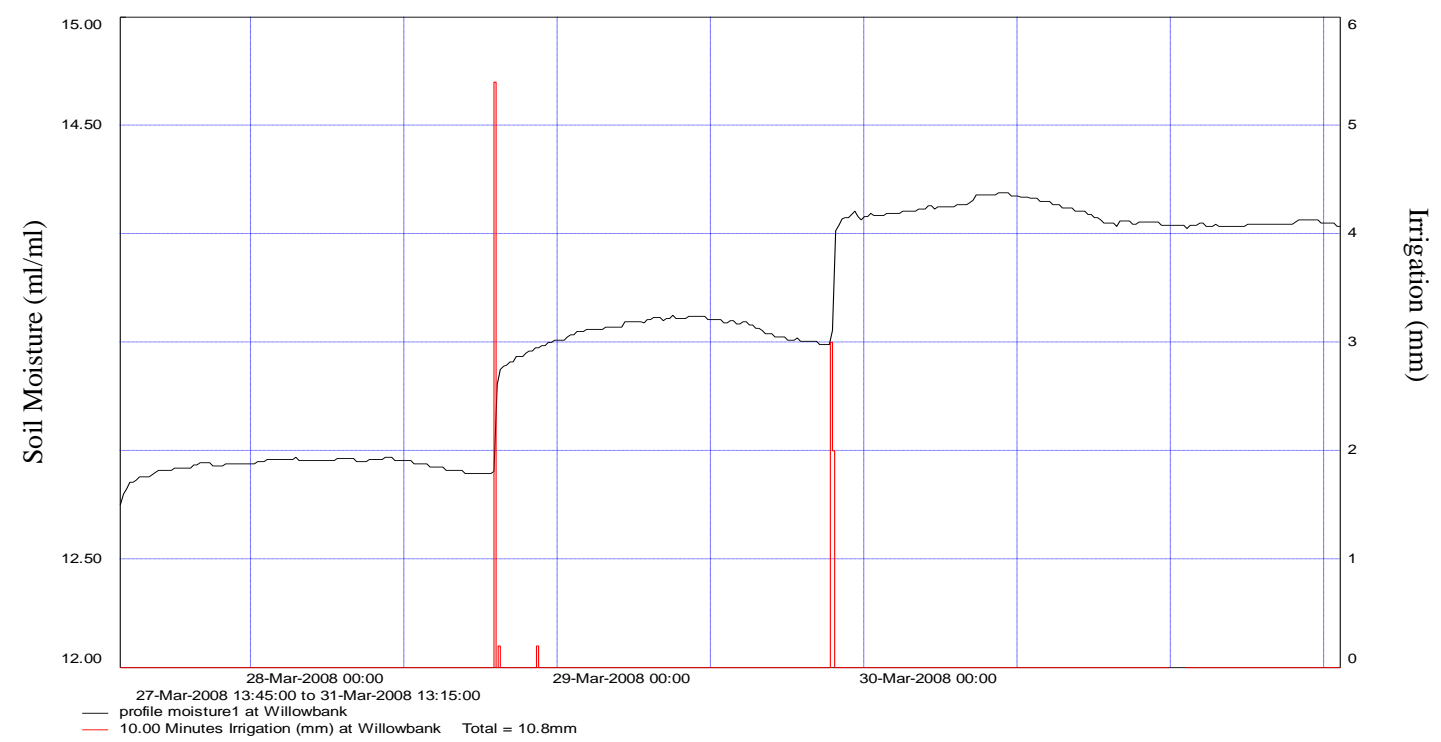

Figure 7.4. Willowbank Profile Moisture - average of probe depths $(10,20,20,40$ and $60 \mathrm{~cm})$ shown as a volumetric water percentage.

The moisture levels at this site stayed reasonably steady between irrigation cycles although analysis of the data at higher resolution reveals distinct diurnal variations at Willowbank. This could be attributed to instrument effects. However, a study by Seyfried et al., (2001) showed that at low water contents, and over a $40{ }^{\circ} \mathrm{C}$ temperature change, the temperature effect was 
small, no more than 2-3\%. As the water contents in all field areas are arguably low and given temperature range for that time of year was on average $2-15^{\circ} \mathrm{C}$ (NIWA, 2008a), it is reasonable to assume that the visible changes observed are, at least in part, due to diurnal changes in soil moisture caused by evapotranspiration.

It may be that the macropores inherent in the Simons series at the Willowbank site enable evaporation of water at higher rates than elsewhere by providing conduits to the surface and a greater interface between the soil matrix and the atmosphere. In addition the site at Willowbank had been used for pasture performance testing. Holes in the surface were visible where species had been planted - it is possible these provide a conduit for greater exchange in soil moisture providing the diurnal changes seen here (Figure 7.5).

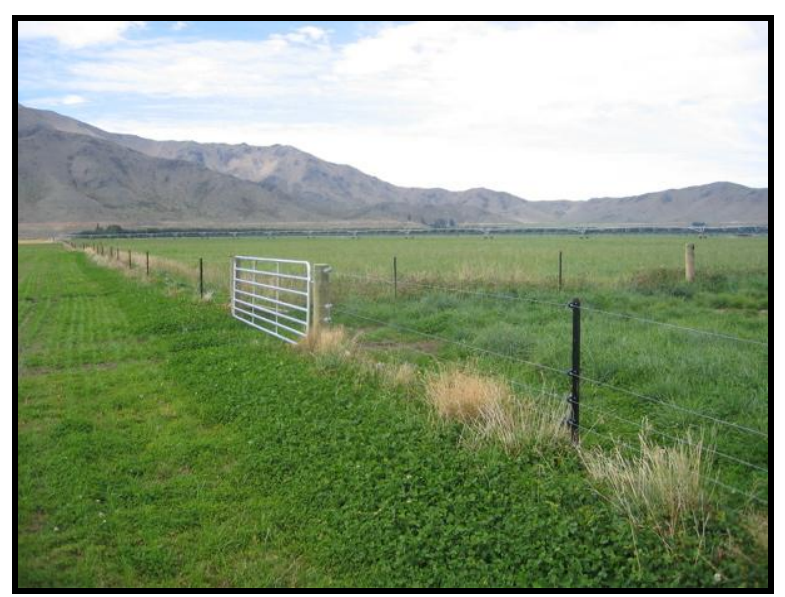

Figure 7.5. Willowbank site prior to installation (left foreground) showing lines of inseminated pasture species.

Interestingly soil moisture at $40 \mathrm{~cm}$ at this site is lower than at $60 \mathrm{~cm}$ (Figure 7.6). Even soil moisture at $30 \mathrm{~cm}$ was initially drier than at $60 \mathrm{~cm}$. It remained that way until the second irrigation pass when the soil moisture at $30 \mathrm{~cm}$ responded immediately and to equal that at 60 $\mathrm{cm}$. The soil moisture just $10 \mathrm{~cm}$ below this is consistently lower than that of the layer $20 \mathrm{~cm}$ below it. Clearly the lower $20 \mathrm{~cm}$ of the profile (between $40 \mathrm{~cm}-60 \mathrm{~cm}$ ) is unaffected by irrigation. Therefore the moisture present in the bottom layer, must be either from a lack of evapotranspiration at that depth or, more likely, proximity to an unconfined shallow aquifer, which provides a source of moisture. 


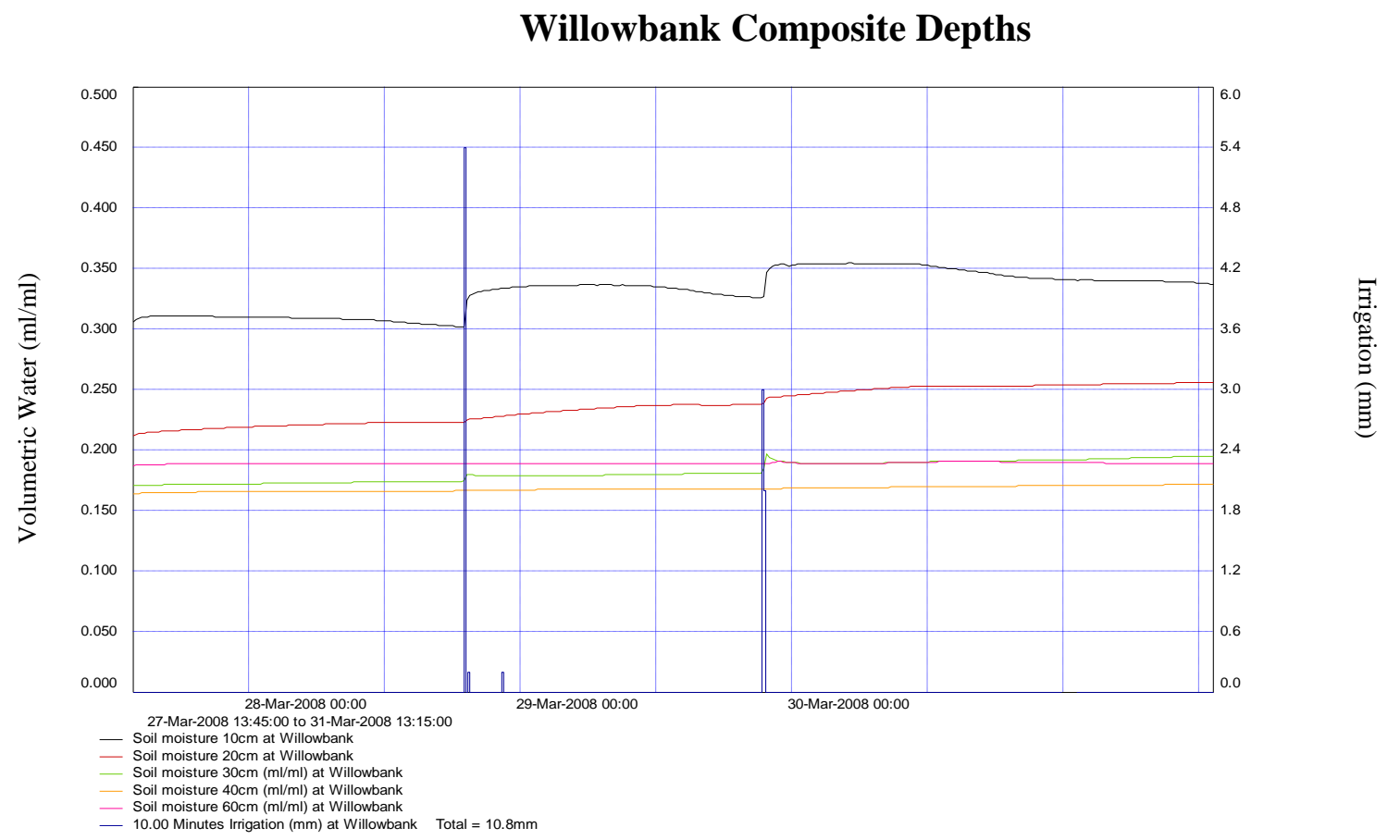

Figure 7.6 Willowbank composite depth soil moisture

Either way Willowbank, like Holbrook, is not over irrigated (at this time) with no evidence of moisture reaching the lower profile. However the existence of the higher moisture at depth indicates that access to moisture from the shallow unconfined aquifer is occurring. This has implications for solute transport and water wastage should irrigation volumes increase.

\section{Wairepo}

Wairepo shows a distinctly different response to irrigation. Wairepo received the second highest irrigation depth $(12.2 \mathrm{~mm})$ and had the shortest gap between irrigation passes $(6 \mathrm{hrs})$. It shows the second highest average profile moisture with an initial value of $15 \%$. However, the response to the second irrigation pass is unique for all the sites tested. At Wairepo it spikes to $29 \%$ (the highest value of all profiles by $10 \%$ ) and then drops rapidly to $22 \%$ (still considerably higher than the initial value).

The following describes in detail what can be seen in figure 7.6 for each depth. The top $30 \mathrm{~cm}$ of the profile responds negligibly to the first irrigation pass. The moisture content remains at $29 \%$ at $15 \mathrm{~cm}$ and $37 \%$ at $30 \mathrm{~cm}$. Both depths respond more to the second irrigation pass. The soil moisture at $15 \mathrm{~cm}$ rises to $36 \%$ and at $30 \mathrm{~cm}$ to $41 \%$; an increase of $7 \%$ and $4 \%$ 
respectively. However at depth 40,60 and $70 \mathrm{~cm}$ the response to the irrigation pass is marked. The moisture content at these depths is between $8-14 \%$; with depth $40 \mathrm{~cm}$ slightly drier (at $12 \%$ ) than depth $60 \mathrm{~cm}$ (at 14\%). All three depths remain unaffected by the first irrigation pass. They respond immediately to the second pass by 'spiking' markedly then dropping slightly. Soil moisture at $40 \mathrm{~cm}$ shows the greatest response as it spikes from $12 \%$ to $46 \%$ then drops to $26 \%$ close to the end of the monitoring. Depth $60 \mathrm{~cm}$ and $70 \mathrm{~cm}$ show a similar response (see figure 7.7).

This indicates that while some soil moisture is held reasonably well in the top $30 \mathrm{~cm}$ of the profile, at saturation excess water makes its way rapidly past the root zone and is transported via macropores out of the soil profile and is in effect wasted. This is an inefficient use of water because any water that is not able to be held in profile, and which bypasses the root zone, is unavailable for plant up-take and therefore growth.

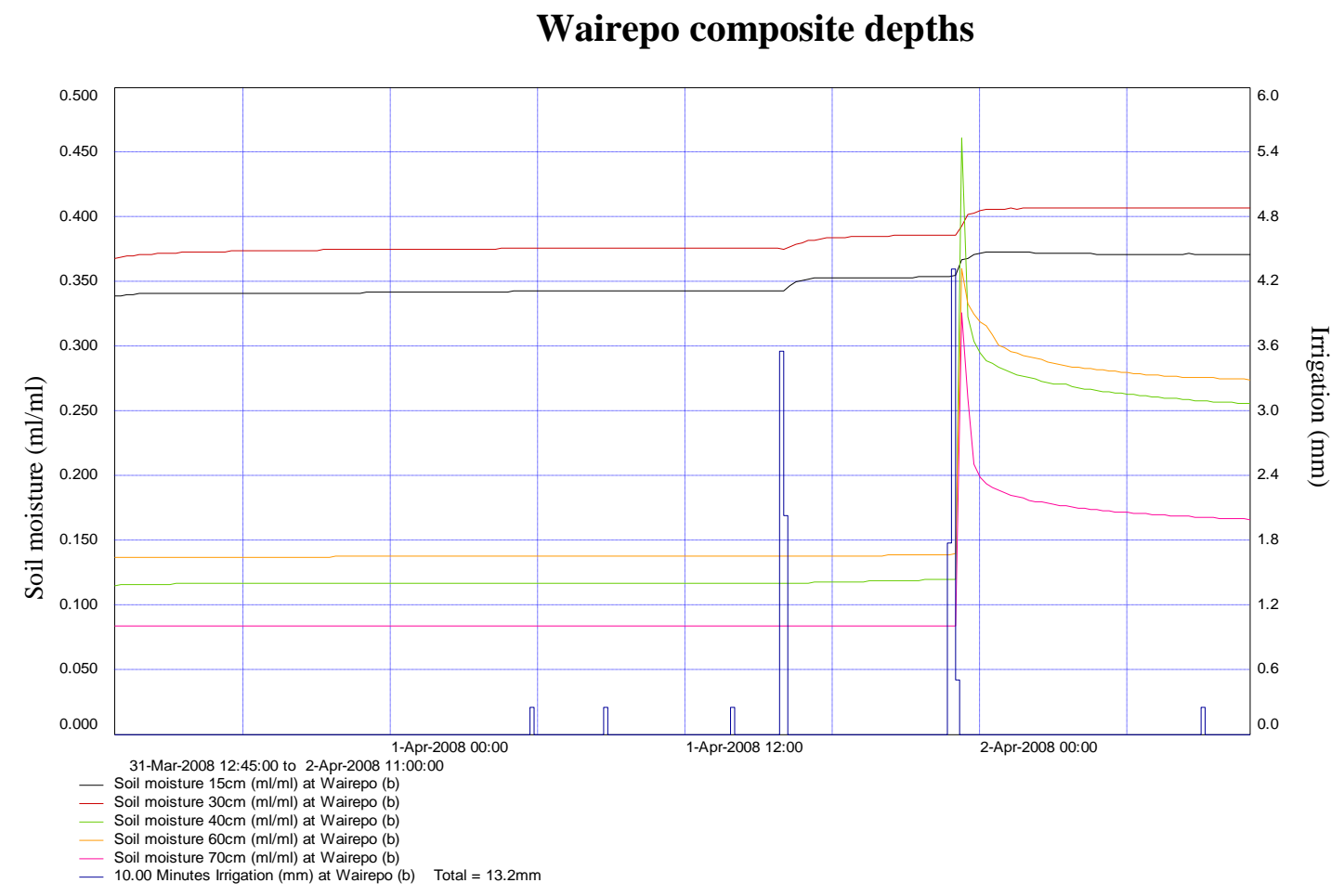

Figure 7.7. Wairepo composite soil moisture showing all depths response to irrigation.

An additional concern with the performance of a soil like this is the soil's ability to transport excess nutrients from nitrogen-based fertilisers and/or pathogens from stock waste or dairy farm effluent to the groundwater. This type of free draining soil effectively becomes a conduit for contaminants to the shallow unconfined aquifers that underlie this area (SKM, 2004b). 
This has implications in terms of cumulative downstream effects (for the health of the hydrological system as a whole but particularly the hydro-lakes and the functioning of power stations) as well as implications for wells providing drinking water. This will be explored further in Chapter 8.

\section{Bendrose}

Bendrose is situated adjacent to the Twizel River, on Mackenzie series soil (as with Wairepo above). This site had the highest depth of irrigation water $(14.5 \mathrm{~mm})$ applied at the slowest rate (50min then 40min). While there were nearly $40 \mathrm{hrs}$ between irrigation cycles, this was not the longest gap between irrigation applications; that was at Holbrook (54hrs). In spite of this, Bendrose had the lowest soil moisture values of all sites.

In addition it had the lowest average profile moisture content at just over 5.5\% (Figure 7.8). This rises over the course of the monitoring to finish at just over $6.5 \%$. As mentioned in chapter 6 this was the only site that displayed a drop in soil moisture on commencement of irrigation, and showed the slowest response.

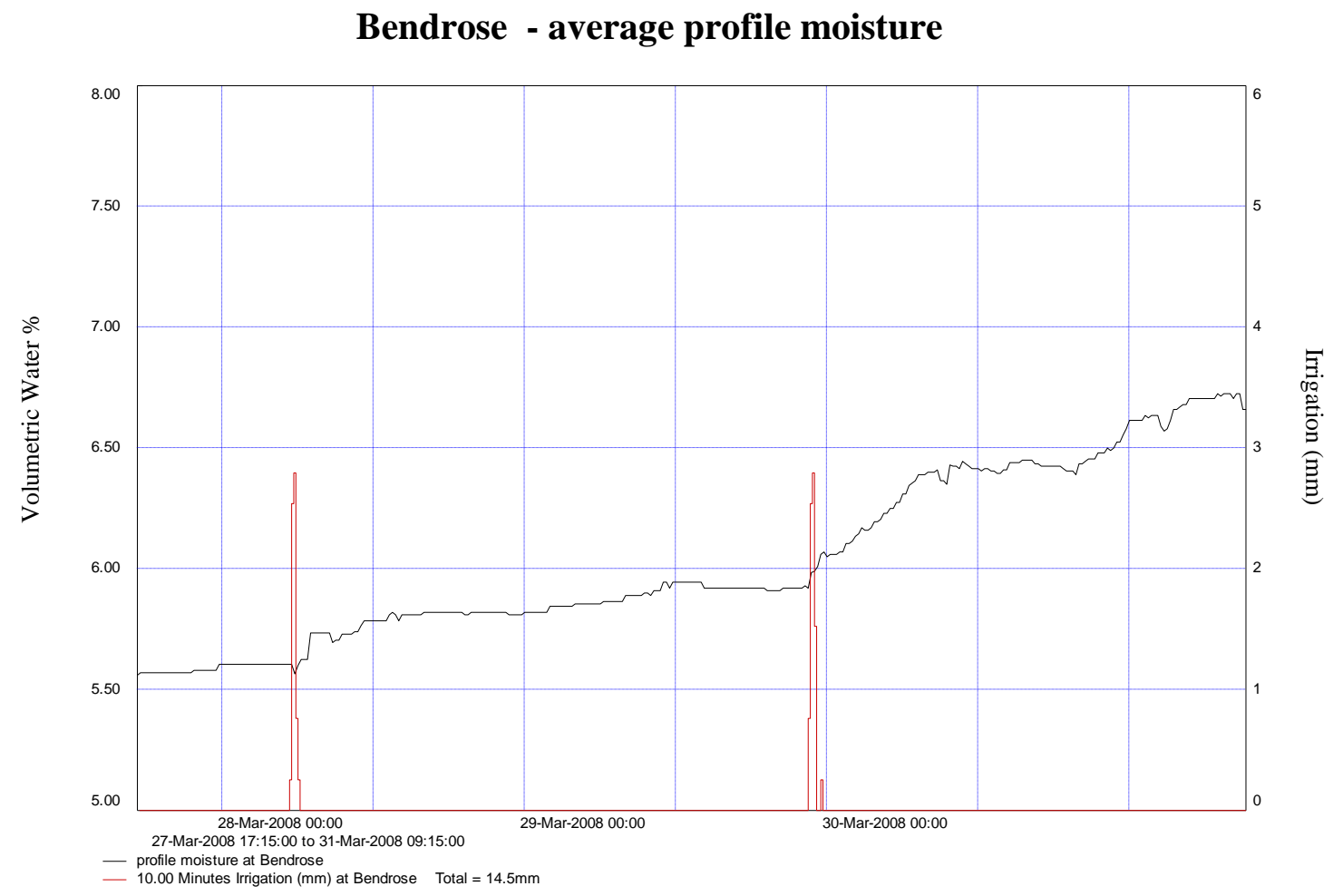

Figure 7.8. Bendrose - total profile moisture average as a percentage. 
From the above analysis, it is possible to conclude that while the area is clearly not over irrigated (illustrated by the lack of soil moisture response at depth and over-all low value), the lack of response in the upper layers suggests that the volume of water applied is at a frequency and rate which is unable to exceed that of evaporation. Consequently irrigation water is unavailable to the plant root zone and therefore effectively wasted. This has clear implications for the efficient use of a resource.

\subsection{Analysis}

Comparison of data from Willowbank and Holbrook shows that while their total irrigation application volumes are very similar $(10.8 \mathrm{~mm}$ at Willowbank versus $10.6 \mathrm{~mm}$ at Holbrook; Table 2) and the irrigation durations are similar (10min then 20min and 20min then $10 \mathrm{~min}$ respectively; Table 2) the initial soil moisture values, illustrated by the values at $30 \mathrm{~cm}$ are quite different (17\% at Willowbank and $26 \%$ at Holbrook) (Figure 7.9).

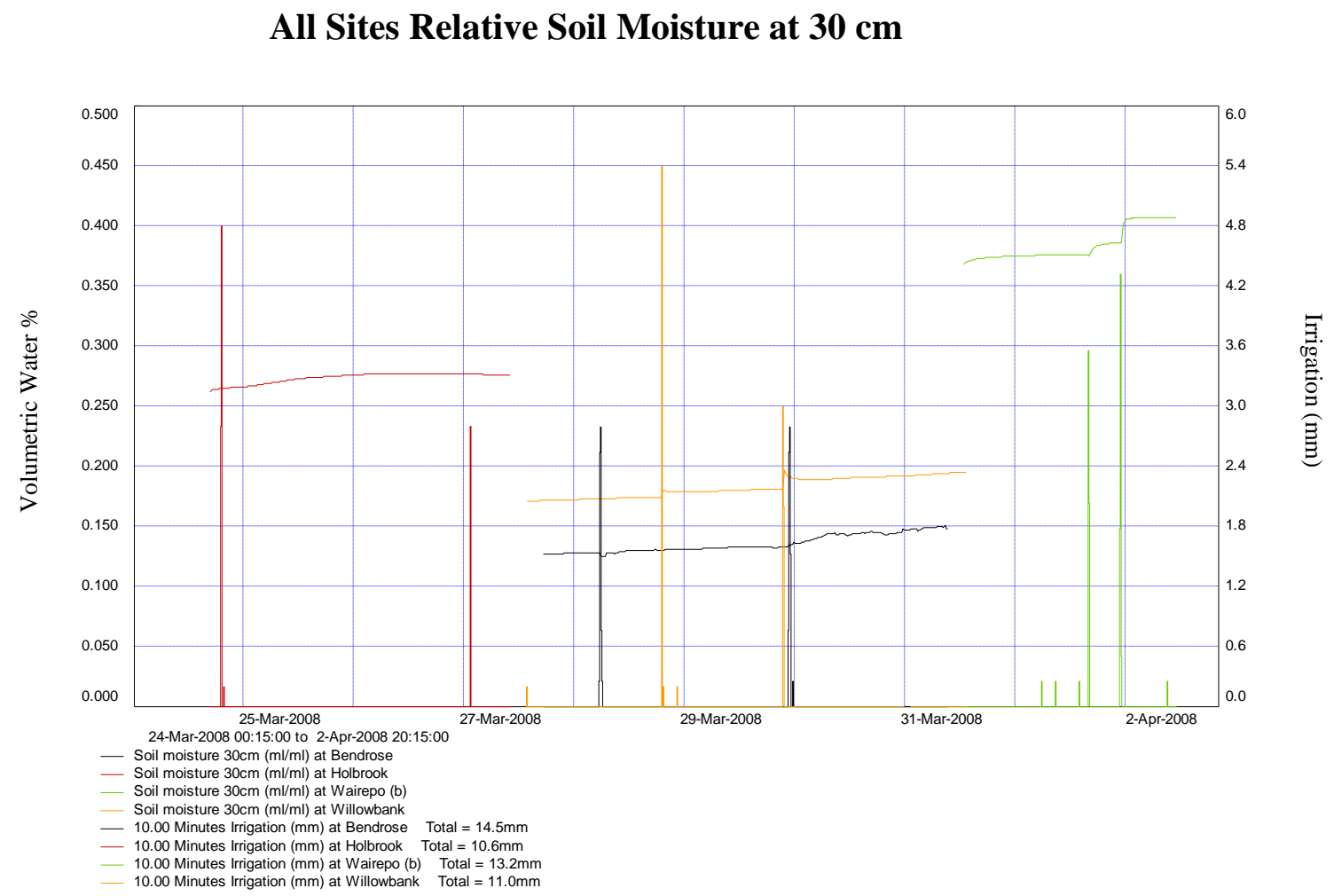

Figure 7.9. All sites relative soil moisture at $30 \mathrm{~cm}$ with irrigation volumes and response to irrigation. 
In addition the response of the top $30 \mathrm{~cm}$ of the profile to irrigation is greater at Holbrook than at Willowbank (Figure 7.10). At Holbrook, the initial soil moisture integrated over the top $30 \mathrm{~cm}$ is $33.6 \%$ this immediately responds to an irrigation volume of $7.6 \mathrm{~mm}$ and rises to $41.4 \%$, an increase of $7.8 \%$ and matches very well to the irrigation volume applied. The initial soil moisture value at Willowbank for the integrated top $30 \mathrm{~cm}$ is $26 \%$, which after $5.6 \mathrm{~mm}$ of irrigation rises to $30.4 \%$ showing that at Willowbank the ability to retain moisture, while still reasonable, is not as effective as at Holbrook. This is a function of the macropores and gravel content of each soil type and reflects their potential suitability for intensive irrigation.

\section{Willowbank (top) and Holbrook (bottom) Vertical Probe (30 cm depth)}
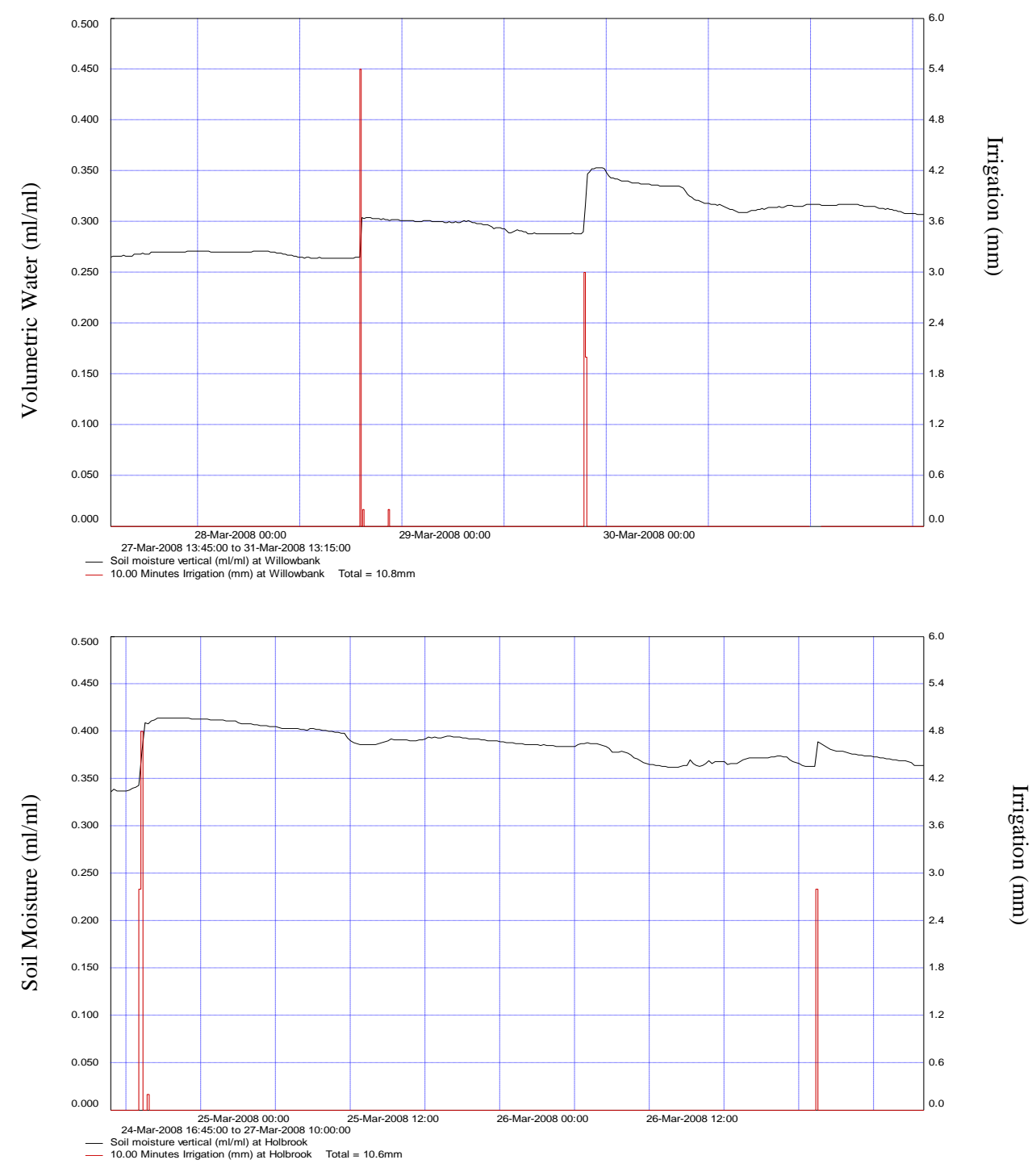

Figure 7.10. Willowbank (top) and Holbrook (bottom) vertical soil moisture over two irrigation cycles, showing response to moisture in the top $30 \mathrm{~cm}$. Clearly Willowbank soil moisture fluctuates more in response to irrigation and does not hold moisture as well as Holbrook. 
Comparison of Bendrose (sheep/cattle) and Wairepo (dairy) is interesting. While they are the same soil series (Mackenzie) they are under different land use and display different rates of pasture growth (Figure 7.11).

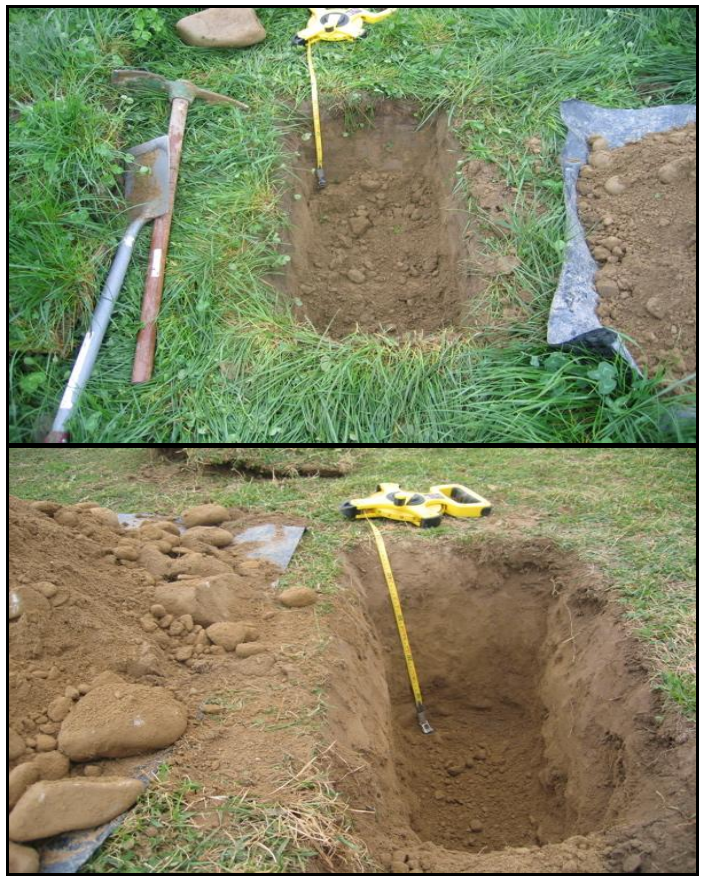

Figure 7.11. Wairepo (top) and Bendrose (bottom) showing the differences in pasture growth on the same soil series under differing irrigation regimes

In addition, they display two distinct responses to irrigation and this is reflected in the antecedent moisture conditions at each site. Wairepo has significantly higher initial soil moisture at $30 \mathrm{~cm}$, than Bendrose (36.5\% versus $13.5 \%$ respectively; Figure 7.12 ).

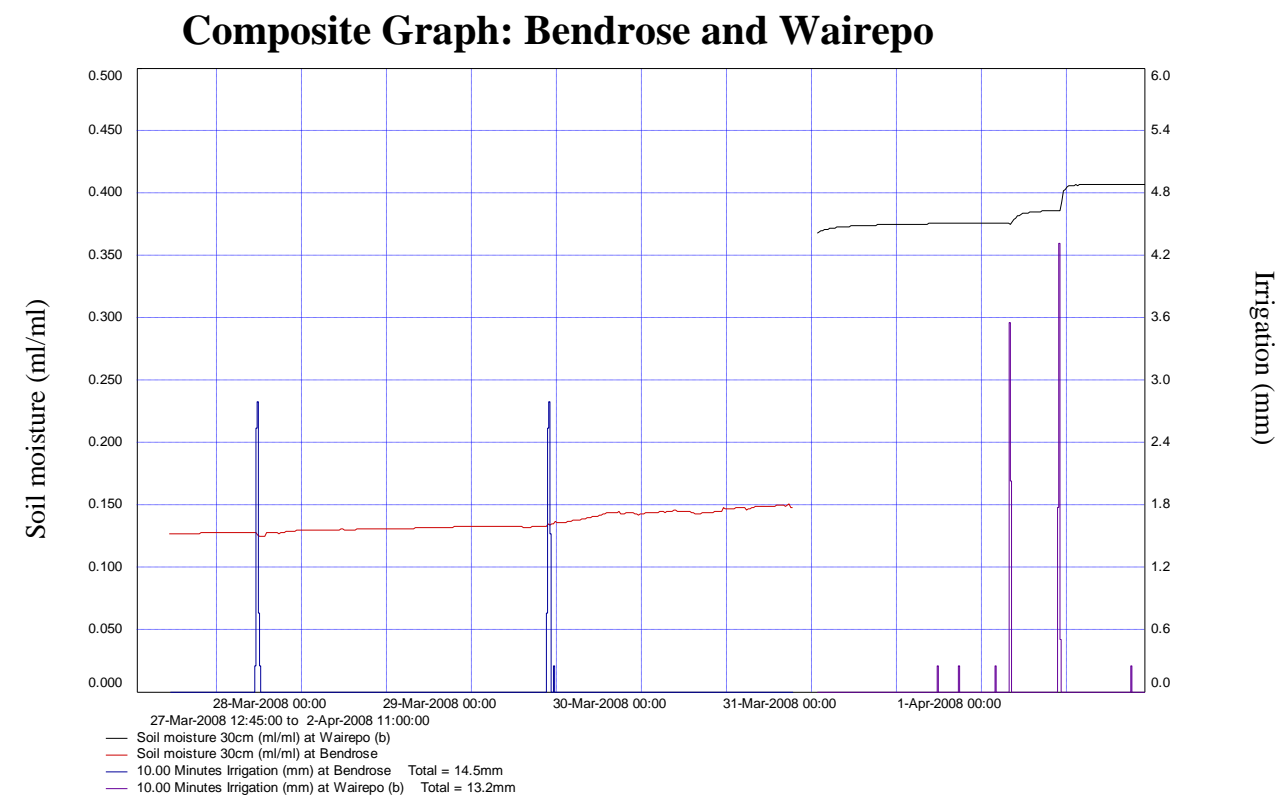

Figure 7.12 Graph of Bendrose (sheep) and Wairepo (dairy) showing relative soil moisture values and response to irrigation of the same soil series under different land use 
Bendrose has a slightly higher application depth $(14.5 \mathrm{~mm}$ versus $13.2 \mathrm{~mm})$ but nearly double the application duration (50min and 40min versus $20 \mathrm{~min}$ then $30 \mathrm{~min}$ ) of Wairepo (Table 2). At Bendrose the response to irrigation is minor, whereas at Wairepo the response at depth to the second irrigation pass is marked. Clearly the application rate and depth at Bendrose is not sufficient to produce the pasture found at Wairepo. It is possible that at the rates of irrigation water applied, the majority of water evaporates before it reaches the root zone and can influence plant growth. Wairepo shows the opposite, that the application rates exceed field capacity and the excess water drains rapidly through the profile.

It could also be argued that the pasture growth at Wairepo is a response to the short irrigation cycle (6hrs versus $40 \mathrm{hrs}$ at Bendrose). While the irrigation cycle is partly caused by the field sites' relative location to the centre-pivots return point, clearly the centre-pivot system is moving at a faster rate and so still effectively applying water more regularly. In addition, the same growth was evident over the whole irrigated area and was not location specific.

The reasons for a drop in soil moisture as a response to irrigation at Bendrose remain unclear. This was the only site to display this effect but it is interesting that it occurred on a soil that displayed such marked infiltration rates at higher application depths (at Wairepo). While the exact reason for this occurring is beyond the scope of this thesis to explore, it is likely to be related to changes in pressure brought on by the additional water and therefore the tension at which existing moisture is held in profile. This provides an excellent opportunity for further study.

This chapter has analysed the field data and drawn conclusions from that. The following chapter, Chapter 8 will discuss the wider implications. 


\section{Chapter 8 - Discussion}

This thesis has aimed to address water allocation and the sustainability of dairying from a resource management perspective. With that in mind it has raised and explored issues that should be included in a discussion on sustainability. As such it has considered the legislation pertaining to these issues and looked at the potential implications of the dairying industry from an environmental effects point of view. The following will review the findings and provide further discussion on certain aspects.

\subsection{Legislation Discussion}

The review of the history and development of the Basin revealed a protracted history of water allocation 'tussles' between the competing uses of electricity generation and agriculture. Recent legislation aimed to balance the increasing demands upon the resource by providing a framework from which individual activities would have an allocated amount attributed to them - agriculture and horticulture, town and community, industrial and commercial etc. From these volumes individual consents could then be considered on the merits of their competing demands. This thesis has argued that the volumes allocated to agriculture in the upper part of the catchment have not clarified the availability of water to potential applicants. The exception to this is to the members of the Mackenzie Irrigation Company (MIC) whose applicants have an existing prior agreement with Meridian, the essence of which is incorporated in the allocation volumes of the Plan (MEL, 2003; Annex1, 2005).

In reality, rights to water were resolved in 2003 during a period of escalating claims to water when Meridian sought clarification of the water permits issued to it in 1999 by CRC. These are valid until 2025. In 2003 a Court declaration found Meridian has the right to all of the water in the upper catchment, which comprises the storage lakes of Tekapo, Pukaki, Ohau, Benmore, Avimore and Waitaki plus 56 kilometres of canal and associated smaller tributaries. Therefore, any water allocated to other users outside of Meridian's side agreements derogates 
from its consents and would be easily contested in a court of law (if it should eventually reach that point). Thus there is no surety of claim for any prospective applicant.

Additionally, by allocating water to an industry other than hydroelectricity generation the Plan has disregarded several studies outlining the changing economic value of water within the length of the catchment, as well as the externalities associated with water use transferred from renewable energy generation to irrigation for agriculture (increasingly intensive dairy farming).

The reason water in the upper part of the catchment (i.e. above the Waitaki Dam) has more economic value than in the lower is due to the sequential configuration of the Waitaki hydro scheme. This scheme comprises eight generating units supplied from six storage lakes. Water from Lake Tekapo flows through all eight generating stations and therefore water from here has a greater generating 'potential' than an equivalent volume from any downstream storage. For example, $8 \mathrm{M} \mathrm{m}^{3}$ of water from Tekapo is capable of generating $9.19 \mathrm{GWh}$ annually of electricity whereas the same volume from Pukaki generates just 5.83 GWh (Meridian; anon. pers. comm.). This raises the question of whether an allocation plan was in fact the right mechanism for water management in the Waitaki or whether another mechanism such as the concept of 'resource rent' as described by Sinner et al., 2007 might have been more effective. This is beyond the scope of this thesis to explore in detail but it is an interesting concept.

\subsection{Fieldwork Discussion}

The fieldwork shows that while the soils tested are able to retain the volumes applied for pasture growth supporting sheep and/or cattle, when subjected to the higher rates of irrigation required to produce the intensive pasture growth for dairying they have the potential to act like a sieve (see Wiarepo, Fig 7.7) . This can be directly attributed to the soil properties, which include (for all sites), having rapid permeability (Webb, 1992); a macroporosity - that is, the expression of the air-filled porosity of the soil at 'field capacity' at 0-0.6 m of class 2 (10-25\% high to very high), thereby indicating the topsoil has plenty of conduits throughout its depth and; a profile readily available water value - that is, the water available to a depth of 
$0.9 \mathrm{~m}$ or to potential rooting depth (which ever is the lesser) of class 4 (moderate: with values ranging between a minimum of $25 \mathrm{~mm}$ (low) and a maximum of $99 \mathrm{~mm}$ (mod-high) $)^{9}$.

Field observation supports these indicator properties of soil hydraulics, with all sites (except Bendrose which had a clay layer - a fragipan) showing a gravely subsoil at or around $0.6 \mathrm{~m}$. From the above values and the fieldwork it is possible to infer that while the soil matrix has the potential to store water at a 'moderate' volume, once field capacity is exceeded the water is rapidly transmitted through the root zone via macropores to the gravels and aquifers below.

The fieldwork was not intended to be a definitive study but was undertaken to highlight the point that while there are some policies and objectives with merit in the regional plan they are currently empty of substance due to the lack of scientific evidence with which to base decisions on. For example, policy 16 requires resource consent applications to meet a reasonable use test including consideration of, land use and soil water-holding capacity, climatic factors such as rainfall variability and potential evapotranspiration, and irrigation system operation and management (WCWRP, 2006) and yet there is limited robust science for this area with which to underpin such a policy.

The fieldwork was conducted to illustrate soil water-holding capacity within the area. Though as mentioned above it was not intended to be a definitive study there are a number of factors which with hindsight would have contributed greatly to the question being asked Firstly, it was limited by being undertaken at the close of the growing season when water restrictions were in place and the volumes of water being applied earlier in the season were, at this time, much reduced. Therefore it did not fully illustrate the soil response to the large applications of water that are the concern of this thesis with regard to long term sustainability. Additionally the use of tensiometers, in addition to the TDR, to determine whether soil was above or below field capacity and close to point of plant stress would have complemented the results obtained from the TDR and rounded out the conclusions nicely. However the results obtained from Wairepo certainly indicate cause for concern and the potential, some might say requirement, for further research done on soil water-holding capacity in this area.

In terms of 'landuse' in policy 16 (see above) as previously mentioned there currently exists no landuse capability study for the upper Waitaki with regard to its suitability for intensive dairy farming. Landcare Research has produced studies of this kind for other regions, but

\footnotetext{
${ }^{9}$ Data from the Landcare Research database LRI - Soils fundamental data layer.
} 
none currently exist for the Waitaki. One is desperately required to enable ECan to have the best information with which to base its decisions regarding consents relating to irrigation and disposal of dairy shed effluent. Purely because the land is flat and there is 'apparently' water to throw at it - doesn't mean we should, no matter what the current commodity value. Lessons learned from the pollution of the North Island lakes - in terms of nitrate transport to groundwater and the timeframes involved for that to both initially become apparent and then be mitigated, should serve as a precautionary lesson and be applied here (GNS, 2007; PCE, 2004).

With regard to 'climatic factors' there is also a gap in the data. During the course of the fieldwork it was hoped to produce a soil-moisture balance using the irrigation data collected on-site and potential evapotranspiration (PET) data from an adjacent monitoring station. However the available PET data, from the closest station to the field area (Tara Hills, Omarama), spans the years 1956 - 1980 (NIWA, 2008a) and none is calculated for recent years. One of the limitations of the field work was that this lack of data was not realised prior to conducting the fieldwork and so measurements at the time of fieldwork were not taken. This arguably would have contributed much to the overall fieldwork conducted. The 2002 Canterbury Strategic Water Study noted that there is a shortage of good quality long-term climate data covering Canterbury's potentially irrigated area. That particular study used the existing data to develop a 'daily time series' and derived a figure for annual average PET of $870 \mathrm{~mm}$ for Omarama and attributed this to the upper Waitaki (Lincoln Environmental, 2002:22). Water use and allocation is emerging as an issue of great challenge to ECan and as PET is an important factor in a soil-water balance and the determination of when to irrigate it would seem prudent to develop such a monitoring program.

In regard to 'irrigation system operation and management', as incorporated into objective 4 of the Plan there is good information on some related aspects such as the efficiency of irrigation systems (Aqualinc, 2006b). Reasonable levels of efficiency are certainly possible with current irrigation systems but this still relies on farmer knowledge and system maintenance (note the difference in anticipated versus actual application rates at Bendrose). It also requires a better method for soil moisture analysis than 'casting an eye over the paddock' or irrigating because allocation is based on a rostered system (Lincoln Environmental 2000; MAF, 2007).

Changing water quantity will also affect water quality. Therefore a closely linked aspect of the sustainability question must include consideration of the cumulative effects of the industry 
on the long-term health of waterways. This includes impacts from irrigation; particularly the intensive irrigation required by dairying coupled with elevated nutrient/pathogen levels from high rates of fertiliser application, dairy-farm effluent disposal (DFED) and the increasingly recognised input from urine patches. These effects have implications for the groundwater system, which in this area consists of shallow aquifers (SKM, 2004b) from which many local landholders draw drinking water (pers. comm.) and for the downstream cumulative effects of algal growth and eutrophication of rivers and lakes.

In New Zealand an application for resource consent must be followed by an environmental effects assessment (EEA), as required by law under the RMA for the activity. However, when compiling an EEA, it is difficult for an applicant to assess the cumulative effects of an activity which is new to an area and it becomes the role of the consenting authority to decide if the effects are no more than minor; and then provide conditions within the consent to monitor and regulate. In the case of water contamination from agricultural practices the effects can take many years to manifest and, depending on flow rates of groundwater, may continue for long time-frames after the activity has ceased (GNS, 2007).

Therefore it would seem prudent and proactive to employ the precautionary principle when allowing an intensification of an activity that, in other areas, has so clearly been linked with waterway degradation including eutrophication. This has necessitated enormous clean up costs around the central north Island lakes (MfE, 2007) and, in the upper Waitaki this potential disaster is compounded by the spin-off effects of algal blooms on hydroelectric infrastructure.

In New Zealand, Local Government has historically been reluctant to employ precaution as a planning rationale preferring instead to rely on conclusive science and in many cases bear clean up costs from poor planning choices. It was hoped that in the course of the fieldwork on soil response to moisture and water use efficiency, some inferences could also be drawn on the viability of continued DFED application to local soils; to produce a degree of certainty of the potential effects to groundwater and thereby enabling a greater degree of regulation surrounding dairying expansion in this region.

The fieldwork is not extensive enough to provide certainty. However, it does indicate the potential of nitrate/pathogen transport to groundwater is present - under certain irrigation regimes, and warrants further investigation. 


\section{Chapter $9-$ Conclusion}

The aim of this thesis was to question the sustainability of dairying in the Upper Waitaki Basin in terms of issues surrounding water allocation and use. The first objective was to gain an understanding of the existing situation. Therefore the thesis began by tracing a history of both hydroelectric generation and irrigation development in the Basin, paying particular regard to the legislation surrounding the allocation of water to various users. What emerged from this was a convoluted history, involving increasing government recognition of the value of the waters of the Waitaki, tempered by local government and landholders trying to secure rights to that water themselves. The resulting interplay spans 40 years as the competing groups sought ever-increasing volumes and developed greater schemes and infrastructure with which to utilise those waters.

Eventually it became apparent that there was insufficient water with which to supply all potential users needs and the inadequacies of having an overarching, permissive policy framework, coupled with a lack of regional planning, were revealed. In an attempt to redress this recent legislation, the 2004 Waitaki Act, was promulgated to clarify allocation between users in the Waitaki catchment. This thesis has argued that in regard to the upper Waitaki it has failed to do so.

This was explored in the second objective of the thesis, which involved a policy analysis of the Waitaki legislation and subsequent Plan. In the process of this it was found that the combined legislation failed to achieve its objective on several points. Firstly the Act was initiated during a volatile time when the two major schemes that initially necessitated it were withdrawn during the drafting process. One by the changing political climate within the area and the other by court declarations clarifying the extent of the existing consent holders water rights. The resulting rewrite of the Bill and the criticism incurred by the government regarding suspicions of ulterior motives(suspected bias toward a State Owned Enterprise Meridian), produced a final draft that leaned so far in the opposite direction to the one the government was accused of, that there is now legislation that specifically excludes an RMA amendment relating to renewable energy generation even though that Act pertains to the largest hydroelectric generation catchment in the country. 
Secondly, the Plan, partly due to being based on flawed methodology, allocated to agriculture a substantial increase in volumetric water, which under common law, if permitted would derogate from the existing consent holders water right. Thus the Plan, rather than clarifying water availability has injected a note of ambiguity regarding who can apply for water from the upper catchment and has reduced certainty regarding the property rights of existing consent holders.

From looking back through the history of the area it is possible to see this as a continuing event in a long line of efforts to provide water to all users for all of the time. This approach is inadequate for good resource management and it does not lend itself to the sustainable development of any industry relying on that water. The centralised planning approach to water allocation undertaken here is unsuccessful in two respects. Water has been allocated in excess to an industry, with the result that, in the upper catchment, it is not the most efficient use of that resource and in so doing ignores the national interest. Further by doing this the Plan effectively disregards an Environment Court ruling, clarifying the extent of existing consents. This results in ambiguity surrounding the availability of water and uncertainty regarding the extent of existing property rights and therefore, rather than providing guidance to the regional council it remains to them to parry a potential legal circus.

This has turned from a situation where the government initially may have sought to give clear direction to the management of a resource but by the focus of both the Act and the Plan has disregarded other related government policy. It appears that the left and right hands know not what either is doing and the resulting confusion is left to the regional council to resolve with what is historically becoming, a traditional lack of clear centralised guidance.

The fieldwork aimed to investigate the efficient allocation of water further by questioning the sustainability of dairying in the upper catchment in terms of environmental effects. The fieldwork looked specifically at soil response to moisture under differing land use. The Basin is a post-glacial outwash plain and as such is composed of fluvio-glacially derived gravels, freely draining with a variable depth of loess-composed topsoil. The climate is continental with cold winters and hot dry summers. This results in a short effective growing season, which then occurs during a time of low rainfall and high evapotranspiration on thin topsoil underlain by gravels. Couple this with an industry that aims to maximise pasture growth by applying high levels of nutrients and water and the problems are not difficult to predict. 
What emerged from the fieldwork was that where water was applied at rates that support the pasture required for sheep/cattle, the soils were able to retain that water for use within the root zone. When water was applied at the rates required for intensive pasture development, this exceeded the soil moisture holding capacity and the soil essentially acted like a sieve. This has clear implications for nutrient/pathogen transport to groundwater systems, and the efficient use of water in terms of the way it is applied but more importantly, the industry to which it is allocated. While the fieldwork is in no way definitive it highlights a need for further investigations and the importance of having robust science available from which Regional Councils can make informed decisions regarding consents for water use.

The final conclusion is that the industry of dairying is not a sustainable activity in the upper part of the catchment. It is unsustainable in terms of economic efficiency of water allocation between users and in terms of the potential cumulative environmental effects in this specific environment. 


\section{References}

Agri-Fax. (2007). The Dairy Report [Electronic Version]. Retrieved 14/10/2008 from http://www.agri-fax.co.nz.

Annex1. (2005). Waitaki Catchment Water Allocation Regional Plan: Annex 1. Retrieved 23/2/2008. from http://www.ecan.govt.nz/Plans+and+Reports/Water/Waitaki+Catchment+Water+Allo cation+Regional+Plan.htm.

Aoraki Water Trust and Others v Meridian Energy Limited (High Court, Timaru 2004).

Aqualinc. (2006a). Snapshot of Water Allocation in New Zealand Aqualinc Research Ltd. for Ministry for the Environment, MfE No.782.

Aqualinc. (2006b). Irrigation Efficiency Gaps - Review and Stock Take. Aqualinc, Research ltd. for The Sustainable Farming Fund and Irrigation New Zealand(Report No Lo5264/2).

Aqualinc. (2008). Sustainable Freshwater Management - Towards an Improved New Zealand Approach. Aqualinc Research Ltd. for New Zealand Business Council for Sustainable Development, Report No H0700/1.

Bell, David. (2008). Geology and Geomorphology - People in the Upper Waitaki Basin: River Life. Retrieved 28/8/2008, from http://www.doc.govt.nz/upload/documents/gettinginvloved/students-and-teachers/themes/river\%20life/people-of-waitaki-basin.pdf

Bittelli, Marco, Fiorenzo Salvatoelli, \& Paola Rossi Pisa. (2008). Correction of TDR-based soil water content measurements in conductive soils. Geoderma, 143, 133-42.

Bosselmann, Klaus. (1991). Sustainability - An International Perspective [Electronic Version]. Planning Quarterly, 6-9. Retrieved 16/10/2008 from http://www.qualityplanning.org.nz.

Brown, Ian, \& Simon Harris. (2005 ). Environmental, Economic and Social Impacts of Irrigation in the Mackenzie Basin. Retrieved 12/4/2008, from http://www.mfe.govt.nz/publications/water/waitaki-impacts-irrigationfeb05/html/index.html

Campbell Scientific Inc. (2007). Instruction Manual TDR100 Reflectometer-based System.

Chandler, D. G., M. Seyfried, M. Murdock, \& J.P McNamara. (2004). Field Calibration of water content reflectometers. Soil Science Society of America Journal, 68, 1501-07.

Chapman Tripp, Barristers \& Solicitors New Zealand. (2003). Waitaki water allocation - a sign of things to come: in Counsel. from www.chapmantripp.co.nz/file_library/material_files/22_september_2003 counsel_.pdf

Clothier, B.E., \& S.R. Green. (1997). Roots: The big movers of water and chemical in soil. Soil Science, 162, 534-43.

Concept Consulting Group. (2004). Project Aqua: An Evaluation of the Economic Impact: Ministry for Economic Development. 
Corwin, D. L., \& S.M. Lesh. (2005). Apparent soil electrical conductivity measurements in agriculture. Computers and Electronics in Agriculture, 46, 11-43.

Cossons, G. G. (1971). Irrigation Investigations in Otago New Zealand viii: Physical Properties of Soils of the Lower Waitaki Plains. New Zealand Journal of Agricultural Research, 14, 539-51.

Cossons, G. G., \& D.S. Rickard. (1970). Irrigation Investigations in Otago, NZ vii: Groundwater and Soil Salinity in the Kurow District. New Zealand Journal of Agricultural Research, 13, 218-24.

Cox, S.C, \& D.J. A. Barrell. (2007). Geology of the Aoraki Area 1;250 000 geological map 15. Lower Hutt, New Zealand: Institute of Geological \& Nuclear Sciences.

Dairy Holdings Inc. (2008). Company Overview. Retrieved 11/12/2008, from http://www.dairyholdings.co.nz/overview.html

Densem, Graham. (2004). Waitaki Landscape Study. Retrieved 12/8/2008. from http://www.waitaki.govt.nz/services/planning/landscape+study.htm.

ECan, Environment Canterbury. (2004). Proposed Canterbury Natural Resources Regional Plan. Chapter 5 - Water Quantity [Electronic Version], RO4/15/5 from http://www.ecan.govt.nz/Plans+and+Reports/NRRPNEW/.

ECan, Environment Canterbury. (2005). Schedule WQN9 Revision: Review of seasonal use approach included in Proposed NRRP [Electronic Version]. Retrieved 15/7/2008 from http://www.ecan.govt.nz/Plans+and+Reports/Water/Schedule+WQN9+Documentatio n.htm.

Ehrenfeld, David. (2005). Sustainability: Living with the Imperfections. Conservation Biology, 19(No. 1), 33-35.

Electricity Group. (2008). Chronology of New Zealand Electricity Reform: Energy and Communications Branch. Retrieved 20/7/2008. from http://www.med.govt.nz/templates/MultipageDocumentTOC_ 6477.aspx.

Evett, Steven R. (Ed.) (2003) Encyclopedia of Water Science. Marcel Dekker, Inc.

Fonterra Co-operative Group, Regional Councils, Ministry for the Environment and Ministry of Agriculture and Forestry,. (2003). The Dairying and Clean Streams Accord,. from http://www.mfe.govt.nz/issues/land/rural/dairying.html

Gardner, W., \& D. Kirkham. (1951). Determination of soil moisture by neutron scattering. Soil Science, 73, 391-401.

GNS, Science Consultancy. (2007). Lake Taupo Catchment Groundwater Age Distribution and Implications for Future Land-Use Impacts: Environment Waikato Regional Council.

Greco, Roberto., \& Andrea Guida. (2008). Field measurements of topsoil moisture profiles by vertical TDR probes. Journal of Hydrology, 348, 442-51.

Hilltop, (2008). http://www.hilltop.co.nz/

Hansard. (2004a). Resource Management (Waitaki Catchment) Amendment Bill - Third Reading. Retrieved 12/12/2008. from http://www.parliament.nz/enNZ/PB/Debates/Debates/6/1/5/47HansD_20040909_00000751-ResourceManagement-Waitaki-Catchment-Amendment.htm.

Hansard. (2004b). Resource Management (Waitaki Catchment) Amendment Bill - in Committee. Retrieved 12/12/2008. from http://www.parliament.nz/en- 
NZ/PB/Debates/Debates/f/9/d/47HansD_20040907_00001214-Resource-

Management-Waitaki-Catchment-Amendment.htm.

Hansen, Blaine R. , Steve Orloff, \& Douglas Peters. (2000). Monitoring soil moisture helps refine irrigation management. California Agriculture, 54(3), 38-42.

Harris, Consulting, New Zealand Institute of Economic Reporting and , Taylor Bains \& Associates, \& (2004). Regional Economic Analysis - Uses Of Water In the Waitaki Catchment. Retrieved 12/4/2008. from www.waitaki.mfe.govt.nz.

Heinzerling, Lisa. (2002). Pricing the Priceless: Cost-Benefit Analysis of Environmental Protection. Georgetown Environmental Law and Policy Institute.

Hewitt, A.E. (1992). New Zealand Soil Classification. Lower Hutt: DSIR Land Resources Scientific Report.

IDG. (1988). South Island Interim Development Group: Environmental Report from the South Island Interim Development Group. Retrieved 12/5/2008. from http://www.med.govt.nz/templates/MultipageDocumentPage 5437.aspx.

Investment NZ. (2006). The New Zealand Energy Sector. Retrieved 12/6/2008. from www.investmentnz.govt.nz/common/ files/NZ\%20Energy\%20Sector\%20Report July\%202006.pdf.

Johnson, R.W.M. (1999). New Zealand's Agricultural Reforms and their International Implications. from www.iea.org.uk/files/upld-book18pdf?.pdf

Kelleners, T. J., M. S. Seyfried, J. M. Blonquist, Jr. J. Bilskie, \& D. G. Chandler. (2005). Improved Interpretation of Water Content Reflectometer measurements in Soils. Soil Science Society of America Journal, 69(6).

Kerr, I.G.C. (1979). Potential minor and major irrigation schemes, Upper Waitaki Catchment. Appendix 4 in Whitby, M.C. : 'Economics of Pastoral Development in the Upper Waitaki'. N.Z. Man and Biosphere Report No. 3. Tussock Grasslands and Mountain Lands Institute, Lincoln College.

Kerr, I.G.C, \& D.W. Ives. (1973). Prospects for Irrigation in the Mackenzie. Tussock Grasslands and Mountain Lands Institute Review, 27, 1-18.

Leisure Matters. (2004). Waitaki Catchment Recreation and Tourism Activities. Retrieved 12/8/2008. from http://www.mfe.govt.nz/publications/water/recreation-tourismwritten-report-dec04/recreation-tourism-written-report-dec04.pdf.

LGESC, The local Government and Environment Select Committee. (2004). Resource Management (Waitaki Catchment) Amendment Bill (96-2) [Electronic Version] from http://www.parliament.nz/enNZ/SC/Reports/c/d/9/cd9a0e44941044ff85afef03e811d8bb.htm

Lincoln Environmental. (2000). A Survey of Farmers' Approaches to \& Perceptions about Irrigation Management. Retrieved. from.

Lincoln Environmental. (2002). Canterbury Strategic Water Study. Retrieved 12/4/2008. from http://www.ecan.govt.nz/plans+and+reports/Water/Canterbury-Strategic-WaterStudy.htm.

Lynn, I.H., L.R. Lilburne, \& P.D. McIntosh. (2002). Testing a soil-landscape model for dry greywacke steeplands on three mountain ranges in the South Island, New Zealand. Australian Journal of Soil Research, 40, 243-55. 
MAF. (2001). Ministry of Agriculture and Forestry - Arable Monitoring Report 2001

Retrieved 18/6/2008, from http://www.maf.govt.nz/mafnet/rural-nz/statistics-andforecasts/farm-monitoring/arable-2001/arable-2001-05.htm

MAF. (2006a). The Dairying and Clean Streams Accord: Snapshot of Progress 2005/06. Retrieved 11/11/2008

MAF. (2006b). Agriculture in New Zealand - past, present and future. Paper presented at the Conference of Agricultural Economies of Australia and New Zealand; Past, Present, Future. Retrieved 12/12/2008, from http://www.maf.govt.nz/mafnet/rural-nz/statisticsand-forecasts/iaae-australia-nz-agriculture/.

MAF. (2007). Pastoral Monitoring Report. Ministry of Agriculture and Forestry.

Malloy, Les. (1993). Soils in the New Zealand Landscape - the living mantle New Zealand Society of Soil Science.

McLaren, R.G., \& K.C. Cameron. (1998). Soil Science: sustainable production and environmental protection (New ed.). Auckland: Oxford University Press.

MEL: Meridian Energy Limited (re an application): Decision number C125/03 (Environment Court 2003).

Meridian, Energy Limited. (2007). Waitaki Power Stations. Retrieved 12/8/2008, from http://www.meridianenergy.co.nz/AboutUs/PowerStations/

MfE. (2004a). Water Programme of Action: Potential Water Bodies of National Importance. Retrieved 25/8/08. from http:www.maf.govt.nz/mafnet/rural-nz/sustainable-resourceuse/water-programme-of-action/national-importance/page9.html.

MfE. (2004b). Departmental Report on Resource Management (Waitaki Catchment) Amendment Act - Report to the Local Government and Select Committee. . Ministry for the Environment.

MfE. (2007). Environment New Zealand 2007. Wellington: Ministry for the Environment, Manatu Mo Te Taiao.

Mildenhall, DC. (2001). Pollen analysis of Pilocene-Pleistocene Kowai Formation (Kurow Group) Mackenzie Basin, South Canterbury, New Zealand. New Zealand Journal of Geology \& Geophysics, 44, 97-104.

Milne, Philip. (2003). Allocation of Water Between Productive Uses. Resource Management Journal, xi(3).

Milne, Philip. (2005). 2005 Salmon Lecture. Allocation of Public Resources under the RMA: Implications of Aoraki Water Trust v Meridian. Resource Management Theory and Practice, 146-87.

Mulet-Marquis, Stephanie, \& John R. Fairweather. (2008). New Zealand Farm Structure Change and Intensification: Agribusiness and Economics Research Unit - Lincoln University.

Nadler, Arie., S. R. Green, I. Vogeler, \& B.E. Clothier. (2002). Horizontal and Vertical TDR Measurements of Soil Water Content and Electrical Conductivity. Soil Science Society of America Journal, 66, 735-43.

NIWA. (2008a). Cliflow Data Base. Retrieved 21/8/2008, from http://cliflo.niwa.co.nz/

NIWA. (2008b). Climate Summaries. Retrieved 12/8/2008, from http://www.niwa.co.nz/edu/resources/climate 
Noborio, K. (2001). Measurement of soil water content and electrical conductivity by time domain reflectometry: a review. Computers and Electronics in Agriculture, 31, 21337.

O'Brien, Joseph J., \& Steven F. Oberbauer. (2001). An Inexpensive, Portable Meter for Measuring Soil Moisture. Soil Science Society of America Journal, 65, 1081-83.

Opus, International Consultants Limited. (2004). Upper Waitaki Catchment: Review of History and Basis of 1969 Order in Council Allowance for Irrigation Opportunities Retrieved 20/2/2008. from http://www.maf.govt.nz/publications.

Paige, Ginger B., \& O Keefer Timothy. (2008). Comparison of Field Performance of Multiple Soil Moisture Sensors in a Semi-Arid Rangeland. Journal of the American Water Resources Association, 44(1), 121.

Patton, Carl, \& David. S. Sawicki. (1993). Basic Methods of Policy Analysis and Planning: Prentice Hall.

Payne, T., N. Shadbolt, E. Dooley, D. Smeaton, \& J. Gardner. (2007). Dairy Farm Ownership and Management Structure: Focus Group Research.

PCE. (2004). Growing for Good: Intensive farming, sustainability and New Zealand's environment. Parliamentary Commissioner for the Environment Wellington.

Raeside, J. D. (1971). Planning For Irrigation In the South Island, New Zealand: New Zealand Soil Bureau, Department of Scientific and Industrial Research.

Reginato, R. J., \& C. H. M. van Bavel. (1964). Soil Water Measurements with Gamma Attenuation. Soil Science of America Journal, 28, 721-24.

Resource Management (Energy and Climate Change) Amendment Act,2004, 2004 No 2.

Rickard, D.S. (1974). A bibliography of Publications 1951-1973: Winchmore Irrigation Research Station.

Robinson, D.A., S.B. Jones, J.M. Wraith, D. Or, \& S.P.Friedman. (2003). A review of Dielectric and Electrical Conductivity Measurement in soils using Time Domain Reflectometry. Vadose Zone, 2, 444-75.

Schlaeger, S. (2005). A fast TDR-inversion technique for the reconstruction of spatial soil moisture content. Hydrology and Earth System Sciences, 9, 481-92.

Seyfried, M. S., \& M.D Murdock. (2001). Response of a New Soil Water Sensor to Variable Soil, Water Content, and Temperature. Soil Science Society of America Journal, 65, 28-34.

Sinner, Jim, James Baines, Hana Crengle, Guy Salmon, Andrew Fenemor, \& Gail Tipa. (2005). Key concepts in Sustainable Development. Part 1: Economics and Ecology. Public Sector, 28.

Sinner, Jim, \& Scherzer Yorn. (2007). The Public Interest in Resource Rent New Zealand Journal of Environmental law, 11.

Skelton, Peter (Commissioner). (2008). Upper Waitaki consent applications recommendation to notify [Electronic Version] from http://crc.govt.nz/Resource+Consents/WaitakiConsents/PlansAndDocuments.htm.

SKM, Sinclair Knight Merz. (2004a). National Cost Benefit Analysis of Proposals to Take Water from the Waitaki River. Ministry of Economic Development, from www.med.govt.nz/templates/MultipageDocumentTOC_10566.aspx 
SKM, Sinclair Knight Merz. (2004b). Waitaki Catchment Groundwater Information: Report prepared for Ministry for the Environment for consideration by the WCWAB.

StatsNZ. (2008). Statistics New Zealand. Retrieved 14/11/2008, from http://www.stats.govt.nz/default.htm

Stevens, Craig. (2003). Waitaki Catchment - nonsense or national necessity? Resource Management Journal, XI(3).

Sullivan, Dr Paul, Bianca Sullivan, \& Jeff Page. (2007). Implementation of Waitaki Catchment Water Allocation Regional Plan: current annual allocation. Retrieved 22/4/2008. from http://www.ecan.govt.nz/Plans+and+Reports/Water/Waitaki+Catchment+Water+Allo cation+Regional+Plan.htm.

Tait, A. B., J. A. Renwick, \& A. H. Stoombergen. (2005). The economic implications of climate-induced variations in milk production. New Zealand Agricultural Research, 48, 213-25.

Taylor, A.R. (1971). A feasibility study of irrigating land with low general grade and broken topography. New Zealand Engineering (newsletter supplement)(15 January).

Taylor, S. A. (1955). Field determination of soil moisture. Agricultural Engineering, 26, 65459.

The Dairying and Clean Streams Accord. (2003). Between Fonterra Co-operative Group, Regional Councils, Ministry for the Environment and Ministry of Agriculture and Forestry. from http://www.mfe.govt.nz/issues/land/rural/dairying.html

The Waitaki Act, Resource Management (Waitaki Catchment) Amendment Act. ,2004, 2004 No 77.

Thompson, Geoff. (2007). The compliance status of dairy shed effluent discharges to land in the Canterbury region for the 2006/2007 season. Prepared for Environment Canterbury, Report No R07/23.

Topp, G. C., Davis K.L., \& Annan A.P. (1980). Electromagnetic determination of soil water content: measurements in coaxial transmission lines. Water Resour. Res., 16, 574-82.

Topp, G. Clarke, \& W. Daniel Reynolds. (1998). Time domain reflectometry: a seminal technique for measuring mass and energy in soil. Soil and Tillage Research, 47(1-2), 125-32.

Walker, Jeffrey P., Gary R. Willgoose, \& Jetse D. Kalma. (2004). In situ measurement of soil moisture: a comparison of techniques. Journal of Hydrology, 293, 85-99.

WCWAB, Waitaki Catchment Water Allocation Board. (2005). Waitaki Catchment Water Allocation Regional Plan - Section 32 Report. from http://www.mfe.govt.nz/publications/water/waitaki-section-32-reportsep05/index.html

WCWAP. (2006). Waitaki Catchment Water Allocation Regional Plan. Retrieved 12 July 2008. from http://www.ecan.govt.nz/Plans+and+Reports/Water/Waitaki+Catchment+Water+Allo cation+Regional+Plan.htm.

WDC, Waimakariri District Council. (2005). Application for the Supply of water. Retrieved 14/8/2008, from www.waimakariri.govt.nz/services/water/QS-U550AA_Application_for_the Supply_of_Water\%20_A3_\%20-\%20July_2008.pd 
Webb, T.H. (1987). Soil Taxonomic Unit Description for Upper Waitaki Basin, South Island, New Zealand. Soil Bureau of New Zealand, 20.

Webb, T.H. (1992). Soils of the Upper Waitaki Basin, South Island, New Zealand (No. 3): DSIR Land Resources.

Webb, T.H. (Cartographer). (1997). Soils of the Upper Waitaki Basin, Maps(1)\&(2)

Webb, T.H., \& A.D Wilson. (1995). A Manual of Land Characteristics for Evaluation of Rural Land: Landcare Research

Western, Andrew W., \& Mark S. Seyfried. (2005). A calibration and temperature correction procedure for the water content reflectometer. Hydrological Processes, 19, 3785-93.

White, R.E. (2000). Principles and Practice of Soil Science - the soil as a natural resource (Third ed.): Blackwell Science.

Wilson, Craig, \& Geoff Burns. (2006). Waitaki District Tourism Strategy 2006 to 2011. Retrieved. from http://www.wdb.co.nz/downloads/waitaki_district_tourism_strategy_2006_to_2011.pd f.

Zazueta, Fedro S., \& Jiannong Xin. (1994). Soil Moisture Sensors. Florida Cooperative Extension Service - University of Florida, 292. 


\section{Appendix A: NZSC Soil Classification}

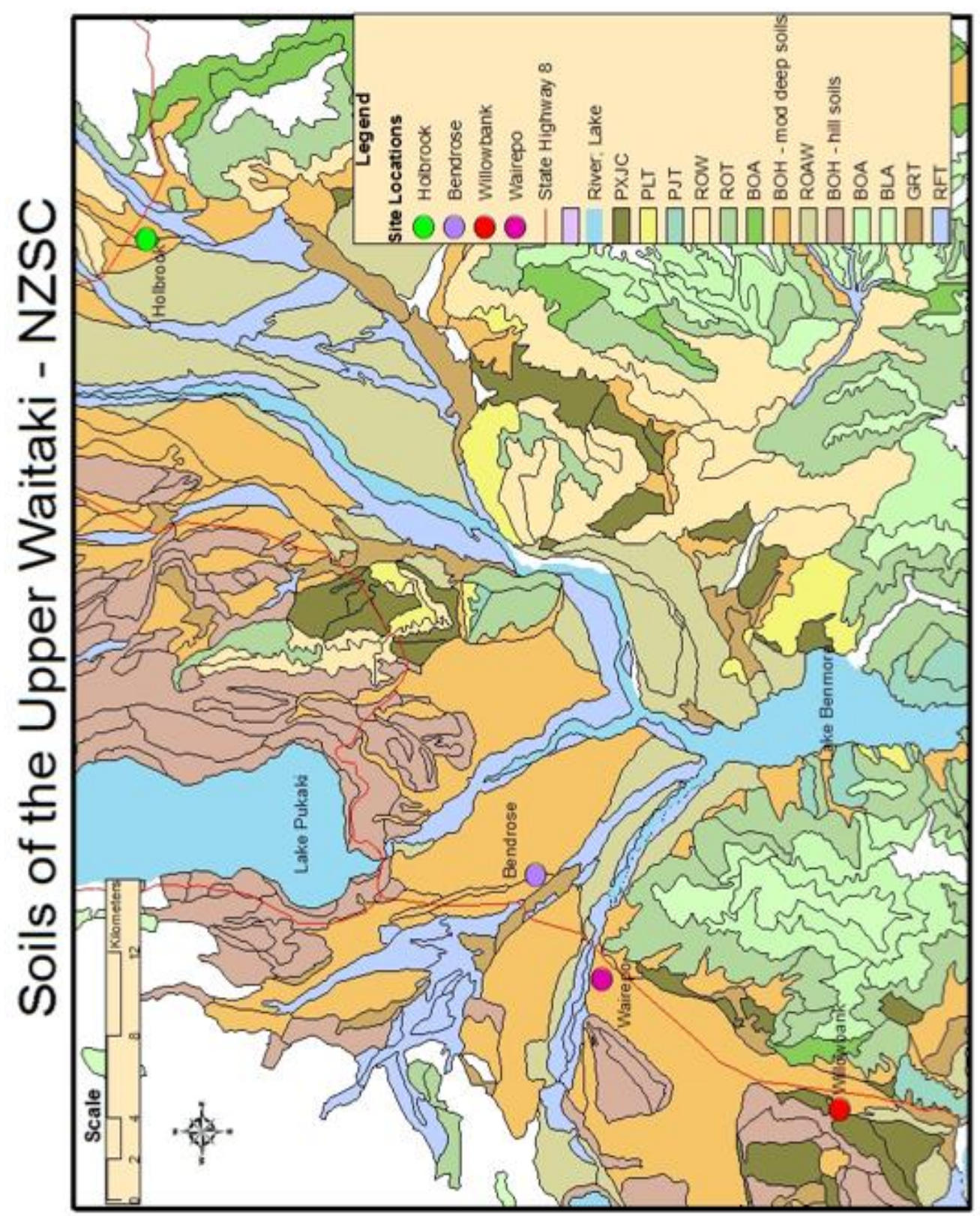

Soil map produced by V. Addison using ArcMap with data from Landcare Research See Hewitt 1992 for soil names from map abbreviations. 


\section{Appendix B: Soil Series of the Upper Waitaki}

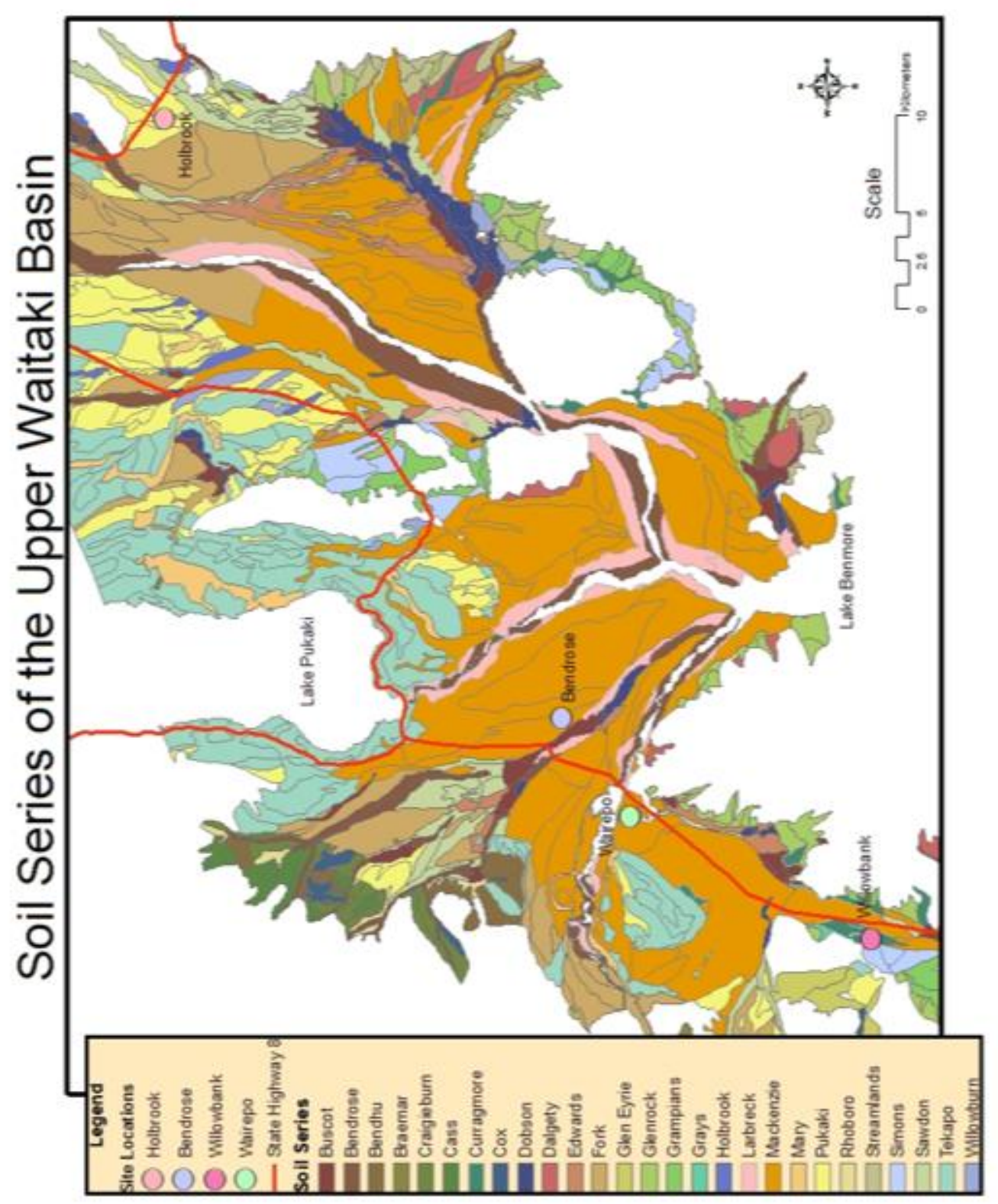

Soil map produced by V. Addison using ArcMap with data from Landcare Research. See Webb 1992 for full description of soil series of the upper Waitaki. 
Appendix C: Canterbury Rainfall summary

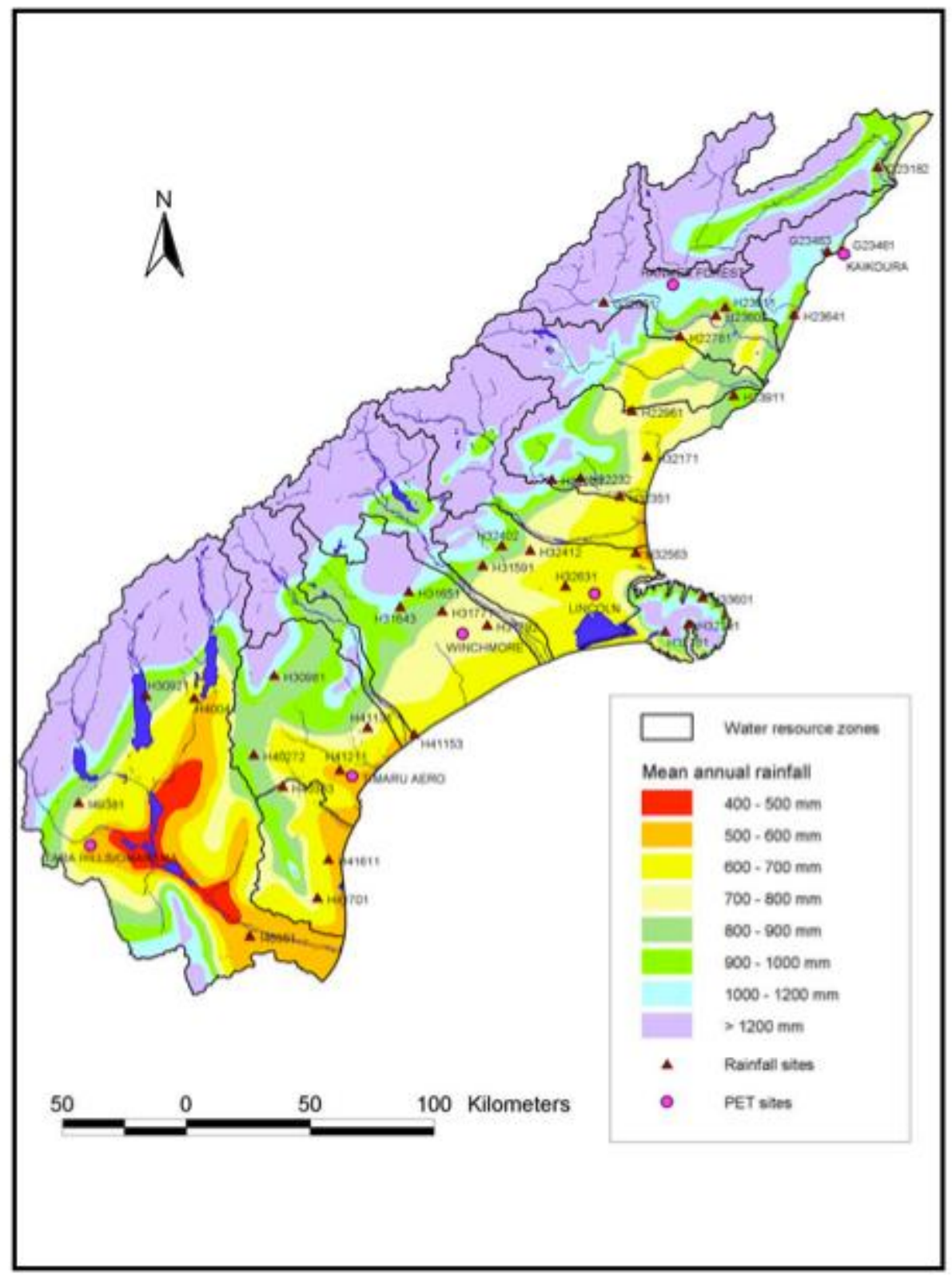




\section{Appendix D: Time Line - showing important legislation and hydroelectricity development}

1935...Waitaki Dam commissioned.

1951...Tekapo A commissioned.

1964...Benmore commissioned.

1966...Interdepartmental Committee Report - to determine the feasibility of irrigation development in conjunction with hydroelectricity development. Report determined 49,000 acres possible by the year 2000 requiring 500 cusecs.

1967...Water and Soil Conservation Act 1967 - changed the structure of water allocation and management in NZ, farmers no longer had unlimited riparian rights.

1968...Order in Council 1968 - declaring waters of the upper Waitaki to be of national importance.

1969...Order in Council 1969 - granted the Minister of Electricity the right to dam, use discharge, divert and take the waters of the upper Waitaki for the purposes of generating electricity. Included within this, in the third schedule was an allocation to irrigation of 520 cusecs ( 15 cumecs) over a 135-day season. Also included were assurances of "compensation water" to cover that required by hydro, and irrigation feasibility studies to assess future outlet capability from generating stations.

$1971 \ldots$ Requests by Mackenzie run holders to the Ministry of Works for irrigation feasibility studies.

1972...Government request for studies on actual uptake required at the present day rather than a projection of future requirements.

1976 ...Further requests by land holders for irrigation studies.

1977...Waitaki Regional Water Board issues a report stating the available land suitable for irrigation would require more than the 15 cumecs currently granted it by the 1969 OIC - the actual demand was estimated at 25.7 cumecs.

Tekapo B commissioned.

1980... Ohau A commissioned.

1982...Waitaki Water and Soil Resource Management Plan (non-statutory) recognised that the majority of water had been declared Waters of National Importance for power generation but that there should be a mix of uses of water in the catchment and recommended a Water allocation Plan be developed to reduce future confusion and conflict.

Irrigation schemes are investigated and constructed on three stations with further outlet capabilities installed at generating stations. Land irrigated totals 11,000 hectares.

1984... Ohau B commissioned.

1985... Ohau C commissioned and this completes the current level of development comprising 8-generating stations with 56 kilometres of canals. 


\section{Appendix D: Time Line-Continued.}

1986...Re-evaluation of the 1966 Interdepartmental Committee Report noted that changes in technology and management have occurred in irrigation since the recommendations were made and while current estimates of land suited to irrigation vary it is in excess of 40, 000 hectares (double the 1966 Reports' recommendation).

State Owned Enterprises Act 1986 passed

1988...ECNZ gains ownership of the infrastructure and water rights to the Waitaki.

$1990 \ldots$ ECNZ and local run holders enter into agreements regarding an allocation to irrigation and these are incorporated into the 'water rights' renewed through the Canterbury Regional Council.

1991...Resource Management Act passed; 'water rights' become 'water permits'.

1999...ECNZ splits into three state owned enterprises - Meridian Energy Limited (MEL) gains the Waitaki infrastructure.

2003 ...(?) March - Aoraki Water Trust (irrigation consortium) applies to Canterbury Regional Council to divert $9 \mathrm{M} \mathrm{m}^{3} /$ week from Lake Tekapo and also applies to the High Court for a declaration to the effect that this is lawful both now and for any future claims in spite of any MEL prior rights.

31 March - MEL applies to Environment Court seeking a declaration on the extent of its resource consents to the waters of the Upper Waitaki.

14 May - MEL lodges applications for Project Aqua.

11 September - Ministerial call-in of all pending consents for water abstractions in the Waitaki Catchment.

12 September - Environment Court rules on the declaration sought by MEL finding that under the non-derogation principle, as more than the annual volume of lake water is allocated to it MEL effectively is entitled to all of the waters of the upper Waitaki. At this same hearing MEL reiterates it will uphold the agreements regarding water volumes for irrigation entered into between ECNZ and stakeholders of 1990.

December - Environment Minister introduces Resource Management (Waitaki Catchment) Amendment Act (Waitaki Act).

2004...6 September - Waitaki Act is passed.

30 September - In inaugural meeting of Waitaki Catchment Water 